

\section{GOVERNO DO ESTADO DE SÃO PAULO}

SECRETARIA DE AGRICULTURA E ABASTECIMENTO

AGÊNCIA PAULISTA DE TECNOLOGIA DOS AGRONEGÓCIOS

INSTITUTO BIOLÓGICO

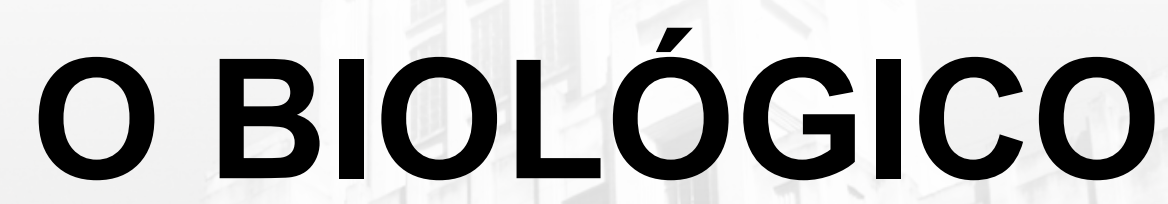

Suplemento 


\title{
O Biológico/Suplemento
}

\author{
v.81, $n^{\circ} 1,2019$
}

\section{Comitê Editorial}

\author{
Editora \\ Ana Eugênia de Carvalho Campos \\ Editor Executivo \\ Márcia Maria Rebouças \\ Conselho Editorial \\ Alessandra Figueiredo de Castro Nassar \\ Ana Eugênia de Carvalho Campos \\ Antonio Batista Filho \\ Eliana Borges Rivas \\ Marcos Roberto Potenza \\ Nayte Vitiello \\ Ricardo Harakava \\ Valmir Antonio Costa
}

Comitê Científico

Ana Maria Iba Kanashiro

André Luiz Matioli

Antonio Carlos Maringoni

Antonio Luiz Cerdeira

Adriana H. C. Nogueira Romaldini

Cecília José Veríssimo

Cláudia Del Fava

Cláudio Marcelo G. de Oliveira

Eliana M. C. Villalobos

Eliane Vieira

Elizabeth A. Lopes Guastalli

Fernando J. Sanhueza Salas

Harumi Hojo

Helena Lage Ferreira

Jane Megid

Jesus Guerino Töfoli
José Eduardo Marcondes Almeida

Luis Francisco A. Alves

Márcia Ortiz Mayo Marques

Marcos C. Gonçalves

Mário Eidi Sato

Renato Luís Luciano

Ricardo S. Jordão

Simone Miyashiro

Teresa Jocys

Vanessa Castro

Vera Cláudia Magalhães Curci

Diretoria de redação

Silvana D'Agostini

Edição Eletrônica

Tânia Cristina Penido Paes Manso 


\title{
17ํㅡㄹ Congresso de Iniciação Científica em Ciências Agrárias, Biológicas e Ambientais- CICAM
}

\author{
Presidente de Honra \\ Ana Eugênia de Carvalho Campos \\ Coordenadora \\ Lígia Maria Lembo Duarte \\ Comissão Organizadora \\ Alexandre Levi Rodrigues Chaves \\ Aline Alves de Souza \\ Alyne de Fátima Ramos \\ Daniela Pontes Chiebao \\ Gézia Cristina Calíopi Macedo \\ Jesus Guerino Tofoli \\ Lívia da Silva Guarnieri \\ Márcia Maria Rebouças \\ Mario E. Sato \\ Nayte Vitiello \\ Pedro Luis Ramos-González \\ Teresa Jocys Kanashiro
}




\section{Apresentação}

É com muita satisfação que apresentamos o $17^{\circ}$ Congresso de Iniciação Científica em Ciências Agrárias, Biológicas e Ambientais - $17^{\circ}$ CICAM.

Com uma programação voltada a Inovação, procuramos selecionar temas que estimulassem o interesse dos jovens estudantes de iniciação científica e de pós-graduação por pesquisas nas áreas relacionadas a sanidades animal e vegetal, bem como em proteção ambiental. Além da importância desse conhecimento, nada melhor do que o tema "Nanotecnologia na agricultura/ambiente", para despertar o interesse dos participantes, dando início aos trabalhos do $17^{\circ} \mathrm{CICAM}$. Contamos, ainda, com palestras ministradas por pesquisadores provenientes de renomadas Instituições de Pesquisa como, EMBRAPA, Institutos Biológico e Butantã, UFSCar, UNESP e USP e da empresa Sakata, que irão engrandecer o nosso evento com temas voltados para melhoramento genético convencional e por transgenia, vegetal e animal, visando ao controle de pragas e doenças; Produção de vacinas através do uso de vetores virais; Sequenciamento de terceira geração; Tratamento microbiológicos e oxidativos de resíduos industriais: Perspectivas e aplicações; Aplicação de ensaios com cultura de células em ambientes biorremediados; Internet of Things e a agricultura e, para fechar com chave de ouro, a palestra "Vida de cientista: os desafios de uma paixão pela natureza".

No $17^{\circ} \mathrm{CICAM}$, assim como em todas as outras edições, além dos 48 resumos aprovados pela Comissão Científica da revista $O$ Biológico, teremos o prazer de receber alunos e pesquisadores de diversas instituições de ensino e pesquisa que, com certeza, contribuirão, não só com a divulgação de seus trabalhos, mas também com suas experiências. Contamos, portanto, com a valiosa participação de representantes do Centro Panamericano de Febre Aftosa/OPS/OMS, RJ; Centro Universitário Fundação de Ensino Octávio Bastos, São João da Boa Vista, SP; Coordenadoria de Desenvolvimento Rural Sustentável, Votuporanga, SP; EDR Votuporanga, SP; Embrapa Mandioca e Fruticultura, Cruz das Almas, BA; Escola Superior de Agricultura Luiz de Queiroz/USP, Piracicaba, SP; Escritório de Defesa Agropecuária de São Paulo, SP; Estação Quarentenária de Cananéia, SP; Faculdade Cantareira, São Paulo, SP; Faculdade de Filosofia, Ciências e Letras - FAFIL, Santo André, SP; Faculdade de Zootecnia e Engenharia de Alimentos/ USP, Pirassununga, SP; Instituto Agronômico de Campinas, Campinas, Cordeirópolis, SP; Instituto Biológico, Campinas, São Paulo, Votuporanga, SP; Instituto Federal Sudeste 


\section{7으 CICAM}

de Minas Gerais, Barbacena, MG; Ministério da Agricultura, Brasília, DF; Parque Rural Fazenda Santa Cândida, Campinas, SP; PUC, Campinas, SP; Sindicato Rural de Votuporanga, SP; Universidade Anhembi Morumbi, SP; Universidade de São Paulo, São Paulo, SP; Universidade Estadual de Santa Cruz, Ilhéus, BA; Universidade Federal do Piauí, Floriano, PI; Universidade Metodista de São Paulo (UMESP), São Bernardo do Campo, SP; Universidade Metodista de São Paulo(UMESP) São Bernardo do Campo, SP; Universidade Paulista, São Paulo, SP; Universidade Presbiteriana Mackenzie, São Paulo, SP e Universidade Santo Amaro, São Paulo, SP.

Para o sucesso do evento, agradecemos a Comissão Organizadora do $17^{\circ} \mathrm{CICAM}$, ao Centro de Administração da Pesquisa e Desenvolvimento do IB, à Silvana D'Agostini e Tânia Cristina Paes Manso pela efetiva colaboração junto à Revista O Biológico. Agradecemos também o Prof. Dr. Leonardo Fernandes Fraceto pela sua presença neste evento, abrilhantando-o com o importante tema de abertura.

Não poderíamos deixar de agradecer ao Prof. Alexandre Croci, por sua sempre presente atenção em treinar os bolsistas do PIBIC/IB para as apresentações orais de seus relatórios finais, durante os CICAMs; ao Comitê do PIBIC/CNPq/IB, composto por Mário S. Sato (Coordenador) e César Júnior Bueno, Márcia Maria Rebouças, Romildo Cássio Siloto, Simone Miyashiro e Cristina Corsi Dib e ao Comitê Externo do CNPq, representado pelos Profs. Drs. Nelson Sidnei Massola Júnior, ESALQ/USP, Marcel Bellato Sposito, ESALQ/ USP, Marcos Bryan Heinemann, FMVZ/USP, Valter Arthur, CENA/USP, Maria Santina de Castro Morini/Universidade de Mogi das Cruzes e Germana Fernandes Barata - UNICAMP.

Expressamos também o nosso agradecimento especial a Dra. Ana Eugênia de C. Campos, Diretora Geral do Instituto Biológico, que não poupou esforços para que o $17^{\circ} \mathrm{CICAM}$ pudesse ser viabilizado.

Agradecemos à FUNDEPAG, sempre presente em nossos eventos, à Nestlé e ao CRBio, que neste ano, também permitiram que a realização do evento fosse possível.

Lígia M. Lembo Duarte

Coordenadora $17^{\circ} \mathrm{CICAM}$ 


\section{Resumos/Contents}

01 - INIBIÇÃO IN VITRO DE ENZIMAS EXTRACELULARES PRODUZIDAS POR FUNGOS FITOPATOGÊNICOS HABITANTES DE SOLO EM MEIO DE CULTURA COM AMINOÁCIDO. In vitro inhibition of extracellular enzymes produced by soilborne phytopathogenic fungi in culture medium with aminoacid. TANCREDO, A.L.G.; CONTENTO, F.M.; BUENO, C.J. DOI: 10.31368/1980-6221c00012019

02 - COMPATIBILIDADE DE PRODUTOS FITOSSANITÁRIOS UTILIZADOS NA CULTURA DOS CITROS AOS FUNGOS Beauveria bassiana, Isaria fumosorosea E Metarhizium anisopliae EM LABORATÓRIO. Compatibility of phytosanitary products used in culture of citrus to fungi Beauveria bassiana, Isaria fumosorosea E Metarhizium anisopliae on laboratory. SOUZA, D.S.; NOWAKONSKI, E.V.; ALMEIDA, J.E.M. DOI: 10.31368/1980-6221c00022019

03 - MONITORAMENTO E CONTROLE BIOLÓGICO DE Meloidogyne graminis EM CAMPO DE GOLFE. Monitoring and biological control of Meloidogyne graminis on golf courses. Campinas, SP, Brasil. ALVES, B.C.; ROSA, J.M.O.; OLIVEIRA, C.G. DOI: 10.31368/1980$6221 \mathrm{c00032019}$

04 - NEMATOIDES FITOPARASITOS ASSOCIADOS À OLIVEIRA (Olea europaea L.) NO ESTADO DE SÃO PAULO. Plant parasitic nematodes associated with olive (Olea europaea L.) in São Paulo state. SANTANA, J. R.; ROSA, J.M.O.; OLIVEIRA, C.M.G. DOI: 10.31368/1980-6221c00042019

05 - EFEITO DA INFESTAÇÃO ENTRE Pratylenchus brachyurus, P. jaehni E Meloidogyne incognita EM Coffea canephora CV. APOATÃ ENXERTADO COM Coffea arabica CV. OURO VERDE. Effect of the interaction among Pratylenchus brachyurus, $P$. jaehni and Meloidogyne incognita in Coffea canephora cv. Apoatã with Coffea arabica cv. Ouro verde. ARAUJO, L.A.C.; EULALIO, J.; KUBO, R.K. DOI: 10.31368/1980-6221c00052019

06 - EXPRESSÃO HETERÓLOGA DE P61, POSSÍVEL GLICOPROTEÍNA DOS CILEVÍRUS, EM PLANTAS TRANSGÊNICAS DE Nicotiana benthamina NahG $^{+}$. Heterologous expression of P61, a putative cilevirus glycoprotein, in transgenic Nicotiana benthamiana $\mathrm{NahG}^{+}$ plants. SCHAAAF BENFICA, C.; ASTÚA-FREITAS, J.; RAMOS-GONZÁLEZ, P.L. DOI: 10.31368/1980-6221C00062019

07 - LEVANTAMENTO DE VÍRUS ASSOCIADOS À LEPROSE DOS CITROS NO CINTURÃO CITRÍCOLA BRASILEIRO. Citrus leprosis associated viruses survey in the Brazilian citrus belt. POTSCLAM-BARRO, M. RODRIGUES, M.C.; CHABI-JESUS, C.; RAMOSGONZÁLEZ, P.L.; FREITAS-ASTÚA, J. DOI: 10.31368/1980-6221c00072019

08 - CARACTERIZAÇÃO PARCIAL DE ISOLADOS BRASILEIROS DO CAULIFLOWER MOSAIC VIRUS EM BRÁSSICAS. Partial characterization of Brazilian cauliflower mosaic virus isolates in brassicas SILVA, V.V.S.; OLIVEIRA, A.M.; RODRIGUES, L.K.; YARA, P.M.; KITAJIMA, E.W.; HARAKAVA, R.; CHAVES, A.L.R.; EIRAS, M. DOI: 10.31368/1980$6221 \mathrm{c00082019}$

09 - ABUNDÂNCIA DE AFÍDEOS E TRIPES VETORES DE VÍRUS EM CAMPOS DE PRODUÇÃO DE OLERÍCOLAS NO CINTURÃO VERDE DE SÃO PAULO. Abundance of aphids and thrips virus vectors in vegetable fields in the green belt of São Paulo. MOURA, C.J.M.; MOURA, S.S.; CHAVES, A.L.R.; EIRAS, M. DOI: 10.31368/1980-6221c00092019

10 - PROPRIEDADES DO EXTRATO INIBIDOR DE INFECÇÃO VIRAL DE Seguieria langsdorffii MOQ. E Pisonia ambigua HEIMERL. Properties of the viral infection inhibitor extract from Seguieria langsdorffii Moq. and Pisonia ambigua Heimerl. PEREIRA, M.V.M.; ALEXANDRE, M.A.V.; CHAVES, A.L.R.; SOUZA, A.C.O.; BERNACCI, L.C.; DUARTE, L.M.L. DOI: $10.31368 / 1980-6221 \mathrm{c} 00102019$ 


\section{7으 CICAM}

Congresso de Iniciação Científica em Ciências Agrárias, Biológicas e Ambientais

Resumos/Contents

11 - LEVANTAMENTO E CARACTERIZAÇÃO PARCIAL DOS PRINCIPAIS VÍRUS QUE INFECTAM A CULTURA DO MILHO NO ESTADO DE SÃO PAULO. Survey and partial characterization of the main viruses infecting corn in the state of São Paulo. NASCIMENTO, T.; HARAKAVA, R.; GONÇALVES, M.C.; DUARTE, A.P. DOI: 10.31368/1980$6221 \mathrm{c00112019}$

12 - LEVANTAMENTO DE VÍRUS TRANSMITIDOS POR ÁCAROS Brevipalpus spp. EM ORQUÍDEAS. Virus lifting transmitted by mites Brevipalpus spp. in orchids. RODRIGUES, M.C.; POTSCLAM-BARRO, CHABI-JESUS, C.M.; TASSI, A.D.; KITAJIMA, E.W.; RAMOS-GONZÁLEZ, P.L.; FREITAS-ASTÚA, J. DOI: 10.31368/1980-6221c00122019

13 - SUSCETIBILIDADE A AZADIRACTINA EM POPULAÇÔES DE Tetranychus urticae (ACARI: TETRANYCHIDAE) PROCEDENTES DE DIFERENTES CULTURAS E REGIÕES BRASILEIRAS. Susceptibility to azadirachtin in populations of Tetranychus urticae (Acari: Tetranychidae) from different crops and Brazilian regions. PEREIRA, E.S.; MARQUES, S.S.; MARÇAL, J.F.; SATO, M.E. DOI: 10.31368/1980-6221c00132019

14 - CAPACIDADE DE PREDAÇÃO DE Iphiseiodes matatlanticae MINEIRO, CASTRO \& MORAES (ACARI: PHYTOSEIIDAE) SOBRE OVOS DE Oligonychus ilicis (MCGREGOR) (ACARI: TETRANYCHIDAE)*. Predation capacity of Iphiseiodes matatlanticae Mineiro, Castro \& Moraes (Acari: Phytoseiidae) on eggs of Oligonychus ilicis (McGregor) (Acari: Tetranychidae). LEAL, M.B.; MINEIRO, J.L.C.; SATO, M.E. DOI: 10.31368/1980$6221 \mathrm{c} 00142019$

15 - COMPORTAMENTO DE ALIMENTAÇÃO E OVIPOSIÇÃO DO ÁCARO Tetranychus urticae KOCH (ACARI: TETRANYCHIDAE) EM FOLHAS DE DIFERENTES ESPÉCIES DE PLANTAS HOSPEDEIRAS. Feeding behavior and oviposition of the mite Tetranychus urticae Koch (Acari: Tetranychidae) on leaves of different species of host plants. RODRIGUES, R.M.P.; MINEIRO, J.L.C.; SATO, M.E. DOI: 10.31368/1980-6221c00152019

16 - ANÁLISE DA TOXICIDADE DE dsGFP EM ENSAIOS DE RNA INTERFERENTE (RNAi) APLICADOS AO ÁCARO DA LEPROSE DOS CITROS. DsGFP toxicity analysis in RNA interference RNA (RNAi) applied to citrus leprosis mite assays. FERREIRA, L.M.; NUNES, M.A.; GALDEANO, D.M.; MACHADO, M.A.; NOVELLI, V.M. DOI: 10.31368/1980$6221 \mathrm{c00162019}$

17 - IDENTIFICAÇÃO GENÉRICA DE Glyptothripini (THYSANOPTERA: PHLAEOTHRIPIDAE, PHLAEOTHRIPINAE) DE SERAPILHEIRA DO PARQUE ESTADUAL DAS FONTES DO IPIRANGA. Genus identification of Glyptothripini (Thysanoptera: Phlaeothripidae, Phlaeothripinae) from leaf-litter of the Fontes do lpiranga State Park. MIYASATO, E.A.; LIMA, E.F.B.; OLIVEIRA, L.A.; EIRAS, M. DOI: 10.31368/1980-6221c00172019

18 - INSETOS (ARTHROPODA, HEXAPODA, INSECTA) COLETADOS EM BACIA HIDROGRÁFICA DE SAPUCAÍ-MIRIM/MG PARA O PROJETO “ÁGUAS DA MANTIQUEIRA": PRIMEIRA APROXIMAÇÃO. Insects (Arthropoda, Hexapoda, Insecta) collected in watershed at Sapucaí-Mirim / MG for the project "Águas da Mantiqueira": First approach TEIXEIRA, I.N.; FRANCO, K.P.A.C.; YAMAKAWA, W.; IDE, S. DOI: 10.31368/1980-6221c00182019

19 - DESCRIÇÃO DOS IMATUROS E ASPECTOS DA BIOLOGIA DE Psyllobora distinguenda (CROTCH, 1874) (INSECTA, COLEOPTERA, COCCINELLIDAE, COCCINELLINAE). Description of immatures and aspects of biology of Psyllobora distinguenda (Crotch, 1874) (Insecta, Coleoptera, Coccinellidae, Coccinellinae). FRANCO, K.P.A.C.; TEIXEIRA, I.N.; IDE, S. DOI: 10.31368/19806221c00192019

20 - MOSCAS-DAS-FRUTAS (DIPTERA: TEPHRITIDAE, LONCHAEIDAE) E SUAS PLANTAS HOSPEDEIRAS NO ESTADO DE SÃO PAULO. Fruit flies (Diptera: Tephritidae, Lonchaeidae) and their host plants in the State of São Paulo, Brazil. LIMA, G.; CRUZ, B.S.; SOUZA-FILHO, M..F.; LOUZEIRO, L.R.F.; RAGA, A. DOI: 10.31368/1980-6221c00202019 


\section{7으 CICAM}

Congresso de Iniciação Científica em Ciências Agrárias, Biológicas e Ambientais

Resumos/Contents

21 - PARASITOIDES (HYMENOPTERA: BRACONIDAE E FIGITIDAE) ASSOCIADOS À MOSCASDAS-FRUTAS (DIPTERA: TEPHRITIDAE) NO ESTADO DE SÃO PAULO. Parasitoids (Hymenoptera: Braconidae and Figitidae) associated with fruit flies (Diptera: Tephritidae) in São Paulo State, Brazil. CRUZ, B.S.; LIMA, G.; SOUZA-FILHO, M.F.; LOUZEIRO, L.R.F.; RAGA, A. DOI: 10.31368/1980-6221c00212019

22 - AVALIAÇÃO DOS FILTRADOS DE BACTÉRIAS SIMBIONTES DE NEMATOIDES ENTOMOPATOGÊNICOS NO MANEJO DE Sclerotinia sclerotiorum E Neofusicoccum parvum. Evaluation of entomopathogenic Nematoid symbiotic bacteria filtrates in the management of Sclerotinia sclerotiorum and Neofusicoccum parvum. FERREIRA, N.; LEITE, L. G.; CHACÓN-OROZCO, J.; OTOYA-MARTINEZ, N.; BUENO, C.J. DOI: 10.31368/1980$6221 \mathrm{c00222019}$

23 - TENTATIVAS DE DIFERENCIAÇ̃̃O DE Xanthomonas spp. CAUSADORAS DA MANCHA BACTERIANA DO TOMATEIRO POR TÉCNICAS SEROLÓGICAS. Attempts to differentiate Xanthomonas spp. the causal agent of tomato bacterial spot by serological techniques. GOMES, C. G.; BERIAM, L.O.S. DOI: 10.31368/1980-6221c00232019

24 - CARACTERIZAÇÃO DE LINHAGENS DE Pseudomonas ISOLADAS DO CAFEEIRO. Characterization of Pseudomonas strains isolated from coffee. BUENO, B.I.; DESTEFANO, S.A.L. DOI: 10.31368/1980-6221c00242019

25 - EFEITO DE DIVERSOS PRODUTOS SOBRE A MANCHA AUREOLADA DO CAFEEIRO, CAUSADA POR Pseudomonas syringae pv. garcae. Effect of resistance inductors on bacterial blight of coffee, caused by Pseudomonas syringae pv. garcae. BEZERRA, L.S; FONSECA, G.A.; DEUS, B.C.; PATRÍCIO, F.R.A. DOI: 10.31368/1980-6221c00252019

26 - AVALIAÇÃO DA SENSIBILIDADE DAS CULTURAS DE SOJA E FEIJÃO SUBMETIDAS A HERBICIDA RESIDUAL. Evaluation of sensitivity of soybean and bean crops submitted to residual herbicide MONTEIRO, T.S.F.; BLANCO, F.M.G.; OLIVEIRA, E.T. DOI: 10.31368/1980$6221 \mathrm{c00262019}$

27 - LEVANTAMENTO DA ENTOMOFAUNA ASSOCIADA A RAÇÕES INDUSTRIALIZADAS COMERCIALIZADAS À GRANEL DESTINADAS A ALIMENTAÇÃO DE CÃES. Study of insect fauna from industrialized dog food sold in bulk. FRANCO, G.M.; POTENZA, M.R. DOI: 10.31368/1980-6221c00272019

28 - TENDÊNCIAS GENÉTICAS DE CARACTERÍSTICAS PRODUTIVAS E REPRODUTIVAS EM BOVINOS NELORE. Genetic trends of productive and reproductive traits in Nellore cattle. MEDEIROS, G.C.; ABREU SILVA, B.C.; ALMEIDA, C.A.; BUSSIMAN, F.O.; EGUTI, F. C.; MATTOS, E.C.; ELER, J.P.; FERRAZ, J.B.S. DOI: 10.31368/1980-6221c00282019

29 - CORRELAÇÕES GENÉTICAS ENTRE VALORES GENÉTICOS ADITIVOS DE CARACTERÍSTICAS PRODUTIVAS E REPRODUTIVAS EM BOVINOS NELORE. Genetic correlations between additive genetic values of productive and reproductive traits in nelore bovine. MEDEIROS, G. C.; ABREU SILVA, B. C.; ALMEIDA, C.A.; BUSSIMAN, F.O.; EGUTI, F.C.; MATTOS, E.C.; ELER, J.P.; FERRAZ, J.B.S. DOI: 10.31368/1980-6221c00292019

30 - ESTIMAÇÃO DE PARÂMETROS GENÉTICOS COM EFEITO MATERNO PARA CARACTERÍSTICAS DE CRESCIMENTO EM OVELHAS DA RAÇA SANTA INÊS. Estimation of genetic parameters with maternal effects for growth traits in Santa Ines sheep. ACERO VADERRAMA, A.S.; SANTANA, B.F.; ABREU SILVA, B.C.; BUSSIMAN, F.O.; GRIGOLETTO, L.; MATTOS, E.C.; ELER, J.P.; FERRAZ, J.B.S. DOI: 10.31368/1980-6221c00302019

31 - COMPARAÇÃO DE MODELOS UNI CARACTERÍSTICA NA ESTIMAÇÃO DE PARÂMETROS GENÉTICOS EM OVELHAS DA RAÇA SANTA INÊS. Comparison of single-trait model in the estimation of genetic parameters in Santa Inês sheep. ACERO VADERRAMA, A.S.; SANTANA, B.F.; ABREU SILVA, B.C.; BUSSIMAN, F.O.; GRIGOLETTO, L.; MATTOS, E.C.; ELER, J.P.; FERRAZ, J.B.S. DOI: 10.31368/1980-6221c00312019 


\section{7으 CICAM}

Congresso de Iniciação Científica em Ciências Agrárias, Biológicas e Ambientais

Resumos/Contents

32 - APLICABILIDADE DOS MÉTODOS MCMASTER E FAMACHA ${ }^{\odot}$ EM OVINOS CRIADOS EM PEQUENA PROPRIEDADE RURAL. Applicability of McMaster and FAMACHA ${ }^{\circ}$ methods in sheeps in small rural property. PASSOS, V.T.; RIGAMONTE, B.L.; ROMERA, D.M.; SILVA, R.A.; SILVA, G.S. DOI: 10.31368/1980-6221c00322019

33 - HELMINTOS PARASITOS DE OVINOS EM PEQUENAS PROPRIEDADES NOS MUNICÍPIOS DE VALENTIM GENTIL, MERIDIANO E VOTUPORANGA, REGIÃO NOROESTE DO ESTADO DE SÃO PAULO. Helminths parasites of sheep in small properties in the Valentim Gentil, Meridiano and Votuporanga, northeast region of Sao Paulo State. RIGAMONTE, B.L.; PASSOS, V.T.; ROMERA, D.M.; SILVA, R.A.; CAMPOLI, C.C., SILVA, G.S. DOI: 10.31368/1980-6221c00332019

34 - HERPESVIRUS BOVINO TIPOS 1 e 5 E HERPESVIRUS BUBALINO TIPO 1: ESTUDO RETROSPECTIVO EM REBANHOS BUBALINOS DO ESTADO DE SÃO PAULO. Bovine herpesvirus types 1 and 5 and bubaline herpesvirus type 1: retrospective study in buffalo herds of the state of São Paulo. DOMINGOS, A.; ZANCO, G.J.; VIZIGALI, A.C.C.; MARTINEZ, R.R.; MONTEIRO, B.; STURARO, M.J.R., STEFANO, E.; ROMALDINI, A.H.C.N.; CHIEBAO, D.P.; CARUSO, C.; VECCHIO, D.; PITUCO, E.M. OKUDA, L.H. DOI: 10.31368/1980-6221c00342019

35 - APLICAÇÃO DA TÉCNICA DE IMUNOCITOQUÍMICA PARA IDENTIFICAÇÃO DE ROTAVÍRUS EM AMOSTRAS DE FEZES DE SUÍNOS PROVENIENTES DE GRANJAS DO ESTADO DE SÃO PAULO, SP. Application of the immunocytochemistry technique for rotavirus identification in swine feces samples from farms in the State of São Paulo, SP, Brazil. LUZ, L.S.M.; PEDROSO, I.M.; BERSANO, J.G.; MARTINS, A.M.C.R.P.F.; OGATA, R.A.; CATROXO, M.H.B. DOI: 10.31368/1980-6221c00352019

36 - ACHADOS ANATOMOPATOLÓGICOS EM EQUINOS COM MORMO. Anatomopathological findings in equine with glanders. SANTOS, C.B.; FONSECA, A.A.; NASSAR, A.F.C.; ROMALDINI, A.H.C.N.; CHIEBAO, D.P.; MAGRINHO, F.C.B.; DIZ, S.M.L..; LEZIER, D.H.; GONÇALVES, R.C.; ARAÚJO, M.C.S.; SIMÕES, H.M.Q.; ALVIM, A.P.C.S.; POMPEI, J.C.A.; MARQUES, G.H.F.; PITUCO, E.M.; DEL FAVA, C. DOI: 10.31368/1980-6221c00362019

37 - AVALIAÇÃO DA DISTRIBUIÇÃO DE ANTICORPOS ANTI-Toxoplasma gondii EM BOVINOS (Bos taurus) NO BRASIL PELA TÉCNICA DE IMUNOFLUORESCÊNCIA INDIRETA (IFI). Evaluation of anti-Toxoplasma gondii antibodies distribuition in cattle (Bos taurus) in Brazil by the indirect immunofluorescence technique (IFAT). HILST, V.C.; ROMALDINI, A.H.C.N.; OKUDA, L.H.; SEVÁ, A.P. DOMINGOS, A.; CHIEBAO, D. DOI: 10.31368/1980$6221 \mathrm{c} 00372019$

38 - CONTROLE DE CARRAPATOS COM OS FUNGOS Metharizium anisopliae E Beauveria bassiana EM EQUINOS NO HARAS VILA COLONIAL - ANALÂNDIA/ SP - RESULTADOS PRELIMINARES. Treat control with fungi Metharizium anisopliae and Beauveria bassiana in haras Village Colonial - Analândia / SP - Preliminary results. FURLAN, B.P.; DUARTE, F.C.; FIORINI, L.C.; ARAUJO, S.B.S.; ALMEIDA, I.B.; SAMPAIO, P. H. S.; MENDES, M. C. DOI: 10.31368/1980-6221c00382019

39 - EFEITO DA ACLIMATAÇÃO A DIFERENTES TEMPERATURAS SOBRE A SENSIBILIDADE TÉRMICA DA RESPOSTA IMUNE DA RÃ-TOURO (Lithobates catesbeianus). Effect of acclimatization at different temperatures on the thermal sensitivity of the bullfrog's (Lithobates catesbeianus) immune response. LIMA, A.S.; FERREIRA, L. de F.; TITON, S.C.M.; GOMES, F.R. DOI: 10.31368/1980-6221c00392019

40 - QUALIDADE DA ÁGUA DE IRRIGAÇÃO DE HORTALIÇAS FOLHOSAS. Irrigation water quality of leafy vegetables. SOUZA, C.S.M.; PETROCELLI, B.M.; SOUZA, G.S.; FERREIRA, R.C.B.; VIEIRA, E. DOI: 10.31368/1980-6221c00402019 


\section{CICAM}

Congresso de Iniciação Científica em Ciências Agrárias, Biológicas e Ambientais

Resumos/Contents

41 - VALIDAC̄̃̃o DE METOdOLOGIA ANALÍTICA PARA ANÁLISE DE RESÍDUOS DE AGROTÓXICOS EM ÁGUA. Validation of analytical methodology for pesticide residue in water. SOUZA, C.S.M.; PETROCELLI, B.M.; FERREIRA, R.C.B.; VIEIRA, E. DOI: 10.31368/1980-6221c00412019

42 - CARACTERIZAÇÃO DEMOGRÁFICA DOS “ARQUIVOS DO INSTITUTO BIOLÓGICO” (AIB) NO FACEBOOK. Demographic characterization of "Arquivos do Instituto Biológico" (AIB) on Facebook. GABAS, C.M.B.; BACILIERI, S.; FERNANDES, M.J.B.; GALLETI, S.R. DOI: 10.31368/1980-6221c00422019

43 - CONHECIMENTO E EXPANSÃO DAS MÍDIAS SOCIAIS DO PERIÓDICO "ARQUIVOS DO INSTITUTO BIOLÓGICO" (AIB). Knowledge and expansion of the social media of the "Arquivos do Instituto Biológico" (AIB) journal. GABAS, C.M.B.; BACILIERI, S.; FERNANDES, M.J.B.; GALLETI, S.R. DOI: 10.31368/1980-6221c00432019

44 - DETECÇÃO DA DOENÇA DAS PENAS E BICO DOS PSITACíDEOS (BFDV) EM UM ANACÃ (Deroptyus accipitrinus) POR MICROSCOPIA ELETRÔNICA DE TRASMISSÃO (MET). Detection of beak and feather disease (BFDV) in an Red-fan Parrot (Deroptyus accipitrinus) by transmission electron microscopy. PEDROSO, I.M.; LUZ, LS.M.; MARTINS, A.M.C.R.P.F.; CATROXO, M.H.B. DOI: 10.31368/1980-6221c00442019

45 - AVALIAÇÃO DA EFICÁCIA DE VARIEDADES DE FEIJÃO COMUM UTILIZADOS COMO RATICIDA CASEIRO. Evaluation of the effectiveness of common bean varieties used as home-grown rat poison. BARBERO, N.Y.; POTENZA, M.R.; NARCISO, E.S. DOI: 10.31368/1980-6221c00452019

46 - VALIDAÇÃO DE GENES DA FAMÍLIA P450 EM Brevipalpus yothersi (ACARI: TENUIPALPIDAE), ÁCARO DA IEPROSE. Validation of P450 family genes in Brevipalpus yothersi (Acari: Tenuipalpidae), leprosis mite. BASSANI, J.G.; SINICO, T.E.; FREITAS-ASTÚA, J.; FERREIRA, L.M.; NOVELLI, V.M. DOI: 10.31368/1980-6221c00462019

47 - CORRELAÇÕES GENÉTICAS ENTRE VALORES GENÉTICOS ADITIVOS DE ESCORES VISUAIS E CARACTERÍSTICAS REPRODUTIVAS EM BOVINOS NELORE. ALMEIDA, C.A.; MEDEIROS, G.C.; ABREU SILVA, B.C.; BUSSIMAN, F.O.; EGUTI, F.C.; MATTOS, E.C.; ELER, J.P.; FERRAZ, J.B.S. DOI: 10.31368/1980-6221c00472019

48 - TENDÊNCIAS GENÉTICAS ENTRE ESCORES VISUAIS E CARACTERÍSTICAS REPRODUTIVAS EM BOVINOS NELORE. ALMEIDA, C. A.; MEDEIROS, G.C.; ABREU SILVA, B.C.; BUSSIMAN, F.O.; EGUTI, F.C.; MATTOS, E.C.; ELER, J.P.; FERRAZ, J.B.S. DOI: 10.31368/1980-6221c00482019 
INIBIÇÃO IN VITRO DE ENZIMAS EXTRACELULARES PRODUZIDAS POR FUNGOS FITOPATOGÊNICOS HABITANTES DE SOLO EM MEIO DE CULTURA COM AMINOÁCIDO. TANCREDO, A.L.G. ${ }^{1, *} ;$ CONTENTO, F.M. ${ }^{1} ;$ BUENO, C.J. ${ }^{1}{ }^{1}{ }^{1}$ Instituto Biológico, Centro Avançado de Pesquisa em Proteção de Plantas e Saúde Animal CAPSA - Alameda dos Vidoeiros, 1027, CEP 13101-680, Campinas, SP, Brasil. E-mail: analuizatancredo@hotmail.com. In vitro inhibition of extracellular enzymes produced by soilborne phytopathogenic fungi in culture medium with aminoacid.

Fungos de solo causam perdas em diversas culturas econômicas e são difíceis de serem controlados porque produzem estruturas de resistência. Os fungos podem produzir também enzimas extracelulares relacionadas ao processo de patogênese. A arginina é um aminoácido e estudos relatam que a mesma pode inibir a enzima extracelular lacase. O objetivo do presente estudo foi verificar se a arginina pode inibir a produção da lacase de diferentes fungos fitopatogênicos e se inibi também a produção de outras enzimas de diferentes fungos de solo. Os fungos utilizados no estudo foram: Rhizoctonia solani AG-4 $\mathrm{HGI}$; Sclerotium rolfsii; Ceratocystis fimbriata; Verticillium dahliae; Fusarium oxysporum $\mathrm{f}$. sp. cubense e Macrophomina phaseolina. As enzimas estudadas foram amilase, lipase, lacase, carboximetilcelulase, gelatinase e catalase. $O$ inoculo dos fungos foi produzido no meio BDA incubado a $25^{\circ} \mathrm{C}$, no escuro, por 14 dias. Um disco de BDA de $0,5 \mathrm{~cm}$ de cada fungo foi repicado para placas ou tubos contendo meio específico para produção de enzima com adição ou não (controle) de $20 \mathrm{~g} / \mathrm{L}$ de arginina. As placas e os tubos ficaram em BOD, a $25^{\circ} \mathrm{C}$, por 4 dias, no escuro. $O$ delineamento experimental empregado foi o inteiramente ao acaso, em esquema fatorial contendo seis fungos e adição ou não de arginina, com dez repetições. Verificou-se para cada fungo apenas a enzima relatada em literatura, sempre procurando ver a interferência ou não do aminoácido na produção. Para avaliar as enzimas lacase, amilase, lipase e carboximetilcelulase, mensurou-se o diâmetro $(\mathrm{cm})$ do halo da enzima ao redor da colônia. Para as enzimas catalase e getalinase, mediuse a intensidade de produção com auxílio de uma escala de notas, com os valores variando de 1,0 (ausência da enzima) até 4,0 (intensa produção da enzima). O experimento foi repetido duas vezes integralmente. Com os resultados obtidos, concluiu-se que a arginina atua apenas na enzima lacase, reduzindo-a ou suprimindo $100 \%$ a sua produção. Para as demais enzimas, o aminoácido pode estimular ou ser inócuo.

"Bolsista: CNPq/PIBIC/IB 
COMPATIBILIDADE DE PRODUTOS FITOSSANITÁRIOS UTILIZADOS NA CULTURA DOS CITROS AOS FUNGOS Beauveria bassiana, Isaria fumosorosea E Metarhizium anisopliae EM LABORATÓRIO*. SOUZA, D. S..$^{* *}$; NOWAKONSKI, E. V.2; ALMEIDA, J.E.M. ${ }^{2}$ Academica de Ciências Biológicas, PUC Campinas, '2Instituto Biológico, CAPSA-Centro Avançado de Pesquisa em Proteção de Plantas e Saúde Animal ULR Controle Biológico, Rua dos Vidoeiros, 1097, B. Gramado, Campinas-SP, CEP 13101-680. E-mail: dani.sc.100@gmail.com Compatibility of phytosanitary products used in culture of citrus to fungi Beauveria bassiana, Isaria fumosorosea E Metarhizium anisopliae on laboratory.

A mosca-negra-dos-citros Aleurocanthus woglumi, vem causando grandes problemas econômicos, representando uma ameaça à citricultura brasileira, necessitando de medidas fitossanitárias rigorosas para o seu controle. A utilização de controle de pragas associado com mais de um método de controle, é uma alternativa que vem sendo explorada na atualidade, e é de extrema importância a ação desses produtos que podem causar aos fungos, pois esses produtos podem atuar na inibição do crescimento vegetativo, a conidiogênese e a esporulação dos microrganismos. Portanto, o objetivo dessa pesquisa é avaliar a compatibilidade de defensivos fitossanitários aos fungos Beauveria bassiana, Isaria fumosorosea e Metarhizium anisopliae sobre esses agentes de controle. Os testes de compatibilidade de defensivos fitosanitarios, foram preparados meio de cultura junto com os produtos fitossanitários testados com as concentrações recomendadas, em nove placas de petri e depois de solidificação do meio foi realizada a inoculação dos fungos. As placas foram mantidas em câmaras tipo BOD por sete dias. Após esse período, foi realizada a medição do diâmetro das colônias, avaliação da conidiogênese e avaliação de viabilidade dos conídios, por meio da técnica de microcultivo. Os dados foram submetidos ao cálculo do Índice Biológico (IB) para a classificação da toxicidade de agrotóxicos para fungos entomopatogênicos. Foram testados os produtos fitossanitários com principais princípios ativos Enxofre, Imidacloprido, Cloripirifós, Cloreto de Zn Mn, Fosfito de Potássio, Bifentrina, Cyflumetofem, Sulfeto de Mg heptahidratado, Espirodiclofeno, Dimeatoato, Nitrato de Cálcio, Óleo mineral, Bacillus thuringiensis, Molibdato de Sódio, MAP purificado, Uréia, Ácido bórico, Sulfato de Mn monohidratado, Piraclostrobina, Abamectina, Tebuconozol + Trifloxistrobina e Oxicloreto de Cobre. Verificou-se que os produtos Cloripirifós, Ácido bórico, Abamectina, Tebuconozol + Trifloxistrobina e Oxicloreto de Cobre apresentam maior toxicidade sobre os fungos entomopatogênicos IBCB 66 B. bassiana, IBCB 130 I. fumosorosea e IBCB 425 M. anisopliae com base no IB. Já os produtos Enxofre, Bifentrina, Sulfeto de Mg heptahidratado, Dimeatoato, Molibdato de Sódio e Uréia se destacaram como compatíveis aos referentes fungos.

*Apoio PDIP-IB/FAPESP

** Bolsista PIBIC/CNPq/IB 
MONITORAMENTO E CONTROLE BIOLÓGICO DE Meloidogyne graminis EM CAMPO DE GOLFE. ALVES, B.C. ${ }^{1 *}$; ROSA, J.M.O. ${ }^{2}$; OLIVEIRA, C.M.G. ${ }^{2}{ }^{1}$ Pontifícia Universidade Católica de Campinas (PUC-Campinas), Rua Professor Dr. Euryclides de Jesus Zerbini, 1516, Parque Rural Fazenda Santa Cândida, CEP 13087-57, Campinas, SP, Brasil. ${ }^{2}$ Instituto Biológico, Centro Avançado de Pesquisa em Proteção de Plantas e Saúde Animal, CAPSA, Laboratório de Nematologia, Campinas, SP, Brasil. E-mail: beatricealves99@gmail.com.

\section{Monitoring and biological control of Meloidogyne graminis on golf courses.}

Os danos causados por nematoides fitoparasitas nos campos de golfe levam à má qualidade do gramado, redução da tolerância à seca, redução da absorção de nutrientes e causam interferência no percurso da trajetória da bola, prejudicando a prática desse esporte. Recentemente, registrou-se o primeiro relato da espécie Meloidogyne graminis no Brasil causando sérios danos aos gramados de campo de golfe nas cidades de Araras e São Paulo, SP. No entanto, além de medidas preventivas, pouco se conhece sobre seu manejo em áreas infestadas. Assim, o presente estudo teve por objetivos realizar o levantamento e o monitoramento de nematoides em campo de golfe na região de Campinas, com ênfase na identificação de $M$. graminis, e estudar a eficiência de agentes de controle biológico em seu controle em condições de campo. O projeto foi dividido em duas etapas: a primeira consistiu em realizar levantamentos populacionais em campo de golfe da região de Campinas. A segunda consistiu no estudo da eficiência de agentes de controle biológico no controle de M. graminis. Foram retiradas duas subamostras para compor uma amostra composta de solo e raiz em cada um dos 18 greens, totalizando 18 amostras (correspondente ao número de buracos do campo de golfe), encaminhadas para o Laboratório de Nematologia (CAPSA, Instituto Biológico, Campinas, SP). O experimento de avaliação da eficiência de agentes de controle biológico foi conduzido em condições de campo, em área comprovadamente infestada por M. graminis, por meio de análise nematológica, baseando-se nos resultados obtidos no item anterior. Foi adotado o delineamento experimental de blocos ao acaso, com três tratamentos e três repetições (três diferentes greens). Os produtos biológicos, Rizotec (Pochonia chlamydosporia) e um mix de Bacillus subitilis - Bacillus sp. foram diluídos em água e distribuídos com auxílio de pulverizador costal com bico em leque, de alta vazão, nas parcelas correspondentes. O volume de aplicação foi de $300 \mathrm{~L} / \mathrm{ha}\left(3 \mathrm{~L} / 96 \mathrm{~m}^{2}\right)$. Os dados obtidos no monitoramento de $M$. graminis nos diferentes greens indicam sua ampla disseminação. Os agentes de controle biológico utilizados não foram eficientes no controle de $M$. graminis. As razões da ineficiência podem estar relacionadas às doses utilizadas e à forma de aplicação.

*Programa Institucional de Bolsas de Iniciação Cientifica - PIBIC/CNPq/IB - 2018/2019 
NEMATOIDES FITOPARASITOS ASSOCIADOS À OLIVEIRA (Olea europaea L.) NO ESTADO DE SÃO PAULO *SANTANA, J. R. ${ }^{1}$; ROSA, J.M.O. ${ }^{2}$; OLIVEIRA, C.M.G. ${ }^{2}$; ${ }^{1}$ Pontifícia Universidade Católica de Campinas, Rua Professor Dr. Euryclides de Jesus Zerbini, 1516 - Parque Rural Fazenda Santa Cândida, Campinas - SP, Brasil, acadêmica; ${ }^{2}$ Centro Avançado de Pesquisa em Proteção de Plantas e Saúde Animal - Laboratório de Nematologia, Alameda dos Vidoeiros, 1097, CEP 13101-680 - Campinas, SP - Brasil, Pesquisador Científico, Pós Doutoranda. E-mail: joice.rsantana@gmail.com. Plant parasitic nematodes associated with olive (Olea europaea L.) in São Paulo state.

O Brasil vem demonstrando bastante interesse na olivicultura levando em consideração o seu grande valor econômico associado à produção de azeitonas e seu subproduto, o azeite. O estado de São Paulo está se tornando bastante promissor na adaptação das plantas de oliveiras (Olea europaea L.). Contudo, há escassez de informações referentes aos problemas fitossanitários, incluindo os fitonematoides. Portanto, o objetivo do presente trabalho visou realizar um levantamento de espécies de nematoides fitoparasitos associados ao cultivo de oliveira em nove municípios do estado de São Paulo: Cabreúva, Lindoia, Pedra Bela, Piedade, Pindamonhangaba, Pilar do Sul, Santo Antônio do Pinhal, São Bento do Sapucaí e Serra Negra. Os nematoides foram extraídos de $250 \mathrm{~cm} 3$ de solo e 10 gramas de raízes, e a identificação foi realizada em microscopia de luz. Após o levantamento nematológico foi possível identificar a prevalência de duas espécies de nematoides, Helicotylenchus dihystera, presente em 36 das 44 amostras coletadas (82\%), seguido por Pratylenchus brachyurus, presente em 19 das 44 amostras (43\%). Algumas espécies identificadas constituíram novas ocorrências para oliveira no Brasil: $H$. erythrinae, $P$. brachyurus, $P$. zeae, Xiphinema diffusum, $X$. variegatum e $X$. krugi, sendo que já existem registros da ocorrência de parasitismo em oliveiras de $H$. erythrinae na Itália e $P$. zeae na Espanha e Turquia.

*Programa Institucional de bolsas de iniciação cientifíca - CNPq/ PIBIC - 2018/2019 
EFEITO DA INFESTAÇÃO ENTRE Pratylenchus brachyurus, P. jaehni E Meloidogyne incognita EM Coffea canephora CV. APOATÃ ENXERTADO COM Coffea arabica CV. OURO VERDE.* ARAUJO, L.A.C. ${ }^{1,2 * *}$; EULALIO, J. ${ }^{1 * * *} ;$ KUBO, R.K. ${ }^{1}{ }^{1}$ Instituto Biológico, Centro Avançado de Pesquisa em Proteção de Plantas e Saúde Animal, CAPSA, Alameda dos Vidoeiros, 1097, CEP 13101-680, Campinas, SP, Brasil. ${ }^{2}$ Pontifícia Universidade Católica de Campinas, Centro de Ciências da Vida, Graduação em Ciências Biológicas, Campinas, SP, Brasil. E-mail: lucas.yagoni@hotmail. com. Effect of the interaction among Pratylenchus brachyurus, P. jaehni and Meloidogyne incognita in Coffea canephora cv. Apoatã with Coffea arabica cv. Ouro verde.

Na cultura do café, dois grandes gêneros de nematoides, Meloidogyne sp. e Pratylenchus sp. ocorrem comumente em ação conjunta. Para verificar a patogenicidade comparada de Meloidogyne incognita, Pratylenchus brachyurus e Pratylenchus jaehni e o efeito da interação desses nematoides em Coffea canephora cultivar Apoatã enxertado com Coffea arabica cultivar Ouro Verde foi realizado em experimento em casa de vegetação do Laboratório de Nematologia, CAPSA, Instituto Biológico, Campinas, SP. Foram utilizadas dez repetições em cada um dos seis tratamentos: 1. Testemunha sem nematoide, 2. Meloidogyne incognita com densidade populacional inicial $(\mathrm{Pi})(\mathrm{Pi}=2000$ nematoides por planta), 3. Pratylenchus brachyurus $(\mathrm{Pi}=2000)$, 4. Pratylenchus jaehni $(\mathrm{Pi}=2000), 5 . \mathrm{M}$. incognita $(\mathrm{Pi}=1000)+P$. brachyurus $(\mathrm{Pi}=1000), 6$. M. incognita $(\mathrm{Pi}=1000)+P$. jaehni $\mathrm{K} 5$ $(\mathrm{Pi}=1000)$. Aos 122 e 199 dias após a inoculação (DAI) foram avaliadas as alturas das plantas e aos 202 (DAl) foram avaliadas a massa da matéria seca da parte aérea (MSPA), massa da matéria fresca do sistema radicular (MFSR) e a população final. A população final do nematoide $(\mathrm{Pf})$ foi estimada pela contagem dos nematoides extraídos das raízes, obtendo-se o fator de reprodução $(\mathrm{FR}=\mathrm{Pf} / \mathrm{Pi})$. As médias dos valores das variáveis de crescimento da planta (MSPA e MFSR) obtidas nos experimentos foram comparadas pelo teste de Tukey $(P=0,05)$. Não houve diferença estatística entre os tratamentos com relação à MSPA e MFSR. O fator de reprodução para $M$. incognita foi praticamente nulo, enquanto que para $P$. brachyurus e $P$. jaehni as médias do FR foram de 5,1 e 11,3 nos tratamentos infestados isoladamente; de 2,7 e 7,12 para os tratamentos inoculados em conjunto com $M$. incognita, respectivamente. O cafeeiro em estudo comportou-se como altamente resistente a $M$. incognita e suscetível a $P$. brachyurus e $P$. jaehni.

\footnotetext{
*Apoio Consórcio Pesquisa Café/Embrapa Café

**Bolsista CNPq/PIBIC/IB

${ }^{* * * B}$ Bolsista Consórcio Pesquisa Café
} 
EXPRESSÃo HETERÓLOGA DE P61, POSSÍVEL GLICOPROTEÍNA DOS CILEVÍRUS, EM PLANTAS TRANSGÊNICAS DE Nicotiana benthamina NahG ${ }^{+}$. SCHAAAF BENFICA, $C^{1}$;ASTÚAFREITAS ${ }^{2}$, J; RAMOS-GONZÁLEZ, PL ${ }^{3}$; Laboratório de Biologia Molecular, Instituto Biológico, Av. Conselheiro Rodrigues Alves, 1252, CEP 04014002 São Paulo, SP, Brasil; Universidade Federal do ABC. E-mail: camila.benfica97@gmail.com. Heterologous expression of P61, a putative cilevirus glycoprotein, in transgenic Nicotiana benthamiana $\mathrm{NahG}^{+}$plants.

A citricultura é um dos principais setores do agronegócio brasileiro. A leprose dos citros (LC) é uma doença viral que atinge a citricultura latino-americana. Embora de origem multi etiológica, citrus leprosis virus - C (CiVL-C, gênero Cilevirus, família Kitaviridae) é o principal agente causal da LC. CiLV-C produz manchas necróticas ou cloróticas nos frutos, folhas e ramos das plantas infectadas, com maior intensidade nas laranjeiras doces (Citrus sinensis). Apesar de ser uma doença não sistêmica, a infecção reduz a qualidade dos frutos, encurta o tempo de vida da planta e induz a sua morte. A expressão heteróloga da proteína P61 de CiLV-C em plantas de Nicotiana benthamina causa lesões necróticas, acompanhada da acumulação de espécies reativas do oxigênio, e ativação transcricional de genes que codificam proteínas relacionadas com a patogenicidade, por exemplo PR1 e PR2. O conjunto de eventos sugere a possível participação do hormônio ácido salicílico (AS), o qual atua como regulador de diversos processos fisiológicos nas plantas, entre eles a imunidade inata. Para compreender os mecanismos envolvidos na interação planta-CiLV-C e o papel do AS, o presente trabalho examinou a expressão da P61, possível glicoproteína do CiLV-C, em plantas transgênicas de Nicotiana benthamiana que expressam o gene bacteriano NahG. O vetor binário pCAMBIA-2300 contendo o gene $p 61$ de CiLV-C (isolado CRD), foi transformado em células de Agrobacterium tumefaciens GV3101. As culturas foram crescidas em presença de acetoseringona, ressuspendidas em solução de infiltração e infiltradas em duas linhagens de $N$. benthamiana NahG e uma de plantas selvagens. Oito plantas de cada linhagem foram infiltradas em 4 folhas 6 semanas após a germinação. $\mathrm{O}$ experimento foi repetido duas vezes. As áreas infiltradas foram analisadas 5 dias após o tratamento. Não se observou alterações nos locais onde foram infiltradas as colônias contendo pCAMBIA-2300 vazio (controle negativo). Nas regiões infiltradas com as culturas pCAMBIA2300-p61, as plantas selvagens apresentaram lesões leves, enquanto ambas as linhagens de plantas transgênicas apresentaram lesões necróticas marcadas. Os resultados sugerem o possível envolvimento do AS no processo anti-estresse nos tecidos infiltrados. O AS induz genes que codificam chaperonas próprias do retículo endoplasmático e que aliviam o estresse de retículo endoplasmático (ERE). Quando as células eucariotas são incapazes de remanejar o ERE, ativa-se o mecanismo de morte celular. Sendo as lesões necróticas observadas nas plantas NahG consequência da morte celular, os resultados apresentados neste trabalho suportam a hipótese da interação da P61 com o retículo endoplasmático e a interferência com o sistema de secreção das células vegetais. Para entender melhor a ação da P61 sobre os mecanismos de defesa vegetal, o projeto visa: (i) estudar a ação da P61 de outros vírus pertencentes à família Kitaviridae, e (ii) utilizar marcadores moleculares que identificam o ER em resposta a P61.

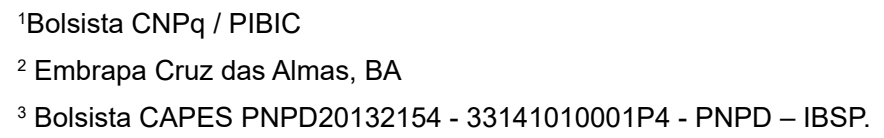


LEVANTAMENTO DE VÍRUS ASSOCIADOS À LEPROSE DOS CITROS NO CINTURÃO CITRÍCOLA BRASILEIRO. POTSCLAM-BARRO, $\mathrm{M}^{1,2^{*}}$. RODRIGUES, M.C..$^{2,3^{*}}$; CHABIJESUS, C. ${ }^{2,4}$; RAMOS-GONZÁLEZ, P.L. ; e FREITAS-ASTÚA, J. ${ }^{2,4}$. 'Universidade Paulista, SP, Brasil. Instituto Biológico, Av. Conselheiro Rodrigues Alves 1252, CEP 04014-900, São Paulo, SP ,2ULR em Biologia Molecular Aplicada SP, Brasil; ${ }^{3}$ Universidade Anhembi Morumbi, SP, Brasil; ${ }^{4}$ Embrapa Mandioca e Fruticultura, Cruz das Almas, BA, Brasil. E-mail: potsclam16@gmail.com. Citrus leprosis associated viruses survey in the Brazilian citrus belt.

Mesmo sendo o maior produtor de laranja do mundo, a citricultura brasileira sofre com diversos patógenos que podem afetar sua produção. Dentre elas está a leprose dos citros (LC), que custa em torno de 60 milhões de doláres por ano para ser controlada. $O$ vírus que causa essa doença, o citrus leprosis virus C (CiLV-C), gênero Cilevirus, família Kitaviridae, está dentro de um grupo denominado Vírus Transmitidos por ácaros do gênero Brevipalpus (Família Tenuipalpidae), os VTBs. O CiLV-C induz sintomas necróticos e/ou cloróticos nos frutos, ramos e folhas de Citrus sinensis L. transmitido principalmente por Brevipalpus yothersi. Nos últimos anos foram sequenciados e caracterizados outros dois agentes causais de leprose, esses são do gênero Dichorhavirus, família Rhabdoviridae, também estão dentro dos VTBs, eles são respectivamente: citrus leprosis virus N (CiLV-N), transmitido por $B$. phoenicis sensu stricto e citrus chlrotic spot virus (CiCSV), com forte associação a $B$. yothersi e $B$. aff yothersi. Além disso foi realizado o primeiro estudo de variabilidade de CiLV-C em 2016 pelo nosso grupo, assim foi possível identificar duas estirpes, Cordeirópolis (CRD), a espécie tipo, e São José do Rio Preto (SJP). Em função da grande importância da leprose, foi estabelecida uma parceria com o Fundo de defesa da Citrucultura (Fundecitrus) que enviou diversas amostras de laranjas sintomáticas, de municípios do estado de São Paulo e Minas Gerais no Cinturão Citrícola. Com isso, o objetivo desse trabalho foi realizar a detecção diferencial dos diferentes vírus e isolados de vírus a partir de RT-PCR com iniciadores específicos e degenerados, além disso foi realizado um levantamento da distribuição geográfica dos dois isolados de CiLV-C no cinturão citrícola. Em 2017 a leprose foi relatada em 37 cidades do estado de São Paulo, sendo que pelo menos metade das amostras possuíam o isolado de SJP. Já em 2018 foram coletadas 188 amostras de cidades do estado de Sâo Paulo e Minas Gerais, a partir dessas amostras foi encontrado em $57,4 \%$ o isolado CiLV-C_SJP, 11,7\% com CiLV-C_CRD, 20,2\% os dois isolados, e 10,6\% foram negativas. Esses resultados mostram que nos anos de 2017 e 2018 o isolado SJP é mais recorrente que CRD, levantando a hipótese de que CiLV-C_SJP pode ser mais agressivo que CiLV-C_CRD. O CiLV-C é predominante nos pomares citrícolas comerciais, não foram encontrados em nenhuma amostra vírus do tipo nuclear enviados no período de 2018. Como o isolado SJP é encontrado em mais da metade das amostras, é possível levantar diversas hipóteses, como o isolado possivelmente ter uma interação melhor com o ácaro, ou que talvez seja mais agressivo em relação ao CRD. Com essas hipóteses criadas, portas poderão ser abertas para pesquisar o real motivo da estirpe SJP ser mais prevalente que CRD nos pomares citrícolas brasileiros.

${ }^{*}$ Bolsista CNPq /PIBIC/IB 
CARACTERIZAÇÃO PARCIAL DE ISOLADOS BRASILEIROS DO CAULIFLOWER MOSAIC VIRUS EM BRÁSSICAS*. SILVA, V.V.S. ${ }^{1,2, * *}$; OLIVEIRA, A.M. ${ }^{2, * * *}$; RODRIGUES, L.K. ${ }^{2}$; YARA,

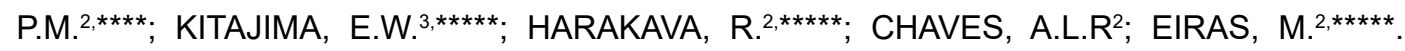
${ }^{1}$ Faculdade Cantareira, R. Marcos Arruda, 729, CEP 03021-000, São Paulo, SP; ${ }^{2}$ nstituto Biológico, Centro de Pesquisa de Sanidade Vegetal, Av. Conselheiro Rodrigues Alves, 1252, CEP 04014-900, São Paulo, SP. ${ }^{3}$ Dep. Fitopatologia e Nematologia, ESALQ, Universidade de São Paulo, CEP 13418-400, Piracicaba, SP. E-mail: virstos04@gmail.com. Partial characterization of Brazilian cauliflower mosaic virus isolates in brassicas.

Espécies de Brassicaceae são amplamente cultivadas no Brasil, com destaque para Brassica oleracea (couve-flor "var. botrytis", couve-manteiga "var. acephala", brócolis "var. italica" e repolho "var. capitata"), B. napus (canola), Brassica rapa (couve-chinesa, mostarda e nabo), Nasturtium officinale (agrião), Raphanus sativus (rabanete) e Eruca sativa (rúcula). Entretanto, a produção dessas olerícolas pode ser acometida por doenças de etiologia viral, incluindo o mosaico induzido pelo cauliflower mosaic virus (CaMV, Caulimovirus). Além das espécies de brássicas de interesse econômico, o CaMV também infecta brássicas da vegetação espontânea como Raphanus raphanistrum (nabiça) e Sinapis alba (mostarda-branca), que desempenham papel de reservatório do vírus em áreas cultivadas. O CaMV possui partículas isométricas com $50 \mathrm{~nm}$ de diâmetro e genoma constituído por um DNA circular de fita dupla com cerca de 8 mil pares de bases $(\mathrm{pb})$. Sua transmissão é realizada por afídeos de modo não circulativo e sua gama de hospedeiros está restrita a brássicas e algumas solanáceas. No Brasil, a ocorrência do CaMV foi registrada em couve-manteiga há 50 anos e, até então, poucos trabalhos sobre a caracterização biológica e molecular de isolados desse vírus haviam sido realizados. Nos últimos anos, pesquisas realizadas no Laboratório de Fitovirologia e Fisiopatologia do Instituto Biológico ampliaram o conhecimento sobre esse vírus, por meio de ensaios empregando gama de hospedeiros, transmissão com diferentes espécies de afídeos vetores e análises moleculares. O presente trabalho teve como objetivo caracterizar isolados brasileiros de CaMV provenientes de diferentes hospedeiras e regiões geográficas denominados: T25, (couve-manteiga/ Divinolândia, SP); T32, T35, T36 e T37 (couve-chinesa/Santo Antônio do Pinhal, SP); T62 e T63 (couve-manteiga/Pindamonhangaba, SP); T89 (couve-manteiga/Ubatuba, SP); T106 (nabiça/ Pinhais, PR) e T109 (nabiça/Pirenópolis, GO). Amostras foliares com sintomas de mosaico e faixa das nervuras foram submetidas à extração de DNA e PCR, utilizando primers específicos para a ORF 1, que codifica a proteína de movimento do CaMV. Fragmentos de DNA com 361 pb foram amplificados, eluídos dos géis e sequenciados pelo método de terminação em cadeia. As sequências obtidas foram alinhadas com outras sequências de caulimovírus depositadas no Genbank, o que permitiu constatar valores de identidade de nucleotídeos e aminoácidos deduzidos acima de $92 \%$ com o CaMV. Nas análises filogenéticas de máxima verossimilhança, observou-se que os isolados brasileiros de CaMV formaram um clado sustentado por valores elevados de bootstrap. Essa baixa diversidade genética sugere que o vírus está sujeito a uma reduzida pressão de seleção, provavelmente devido à sua gama restrita de hospedeiros e origem comum dos isolados brasileiros.

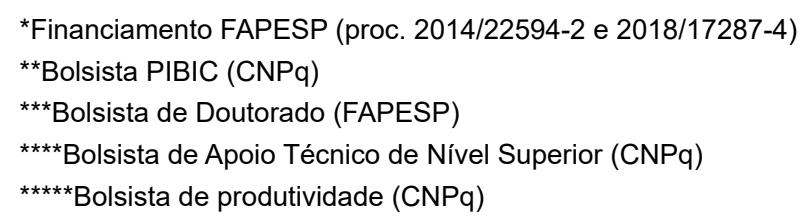


ABUNDÂNCIA DE AFÍDEOS E TRIPES VETORES DE VÍRUS EM CAMPOS DE PRODUÇÃO DE OLERÍCOLAS NO CINTURÃO VERDE DE SÃO PAULO.* MOURA, C.J.M.2***; MOURA, S.S.1,2*; CHAVES, A.L.R.2; EIRAS, M.2**** 1 Faculdade Cantareira, R. Marcos Arruda, 729, CEP 03021-000, São Paulo, SP, Brasil. 'Instituto Biológico, Centro de Pesquisa de Sanidade Vegetal, Av.Conselheiro Rodrigues Alves, 1252, CEP 04014-900, São Paulo, SP, Brasil. E-mail: chaves@biologico.sp.gov.br. Abundance of aphids and thrips virus vectors in vegetable fields in the green belt of São Paulo.

Olerícolas pertencentes às famílias Amaryllidaceae, Apiaceae, Asteraceae e Brassicaceae podem ser infectadas por diferentes espécies de vírus pertencentes aos gêneros Carlavirus, Caulimovirus, Polerovirus e Potyvirus, transmitidos por afídeos (Hemiptera, Sternorrhyncha) e Orthotospovirus, transmitidos por tripes (Thysanoptera). No cinturão verde de São Paulo, muitos produtores cultivam, simultaneamente, diferentes espécies de olerícolas como amarilidáceas (cebolinha), apiáceas (cheiro-verde e coentro), asteráceas (alface e escarola) e brassicáceas (couve-manteiga, couve-chinesa, repolho e brócolis). No entanto, esta prática pode influenciar a dispersão de viroses, uma vez que muitas dessas olerícolas atuam como hospedeiras tanto dos vírus quanto dos insetos vetores. A fim de obter a abundância da fauna afidológica e thysanoptera, no cinturão verde de São Paulo, armadilhas amarelas adesivas foram instaladas em duas propriedades de cultivo intensivo de olerícolas, situadas nos municípios de BiritibaMirim ( $23^{\circ} 34^{\prime} 22^{\prime \prime}$ S $/ 46^{\circ} 02^{\prime} 20^{\prime \prime}$ O) e Ibiúna ( $\left.23^{\circ} 39^{\prime} 21^{\prime \prime} \mathrm{S} / 47^{\circ} 13^{\prime} 22^{\prime \prime} \mathrm{O}\right)$, durante o verão e o outono de 2019. No centro de cada propriedade, delimitou-se uma área de $100 \mathrm{~m} 2$, que foi monitorada durante 45 dias. Em cada área avaliada foi afixada, com auxílio de hastes de $0,75 \mathrm{~cm}$, uma armadilha amarela adesiva nas coordenadas geográficas norte, sul, leste e oeste. As armadilhas foram substituídas quinzenalmente e submetidas a observações em lupa estereoscópica para a contagem dos afídeos e tripes capturados. Durante o monitoramento, foram anotados, diariamente, a temperatura média e a pluviosidade total, para correlacionar o efeito dessas variáveis ambientais sobre as populações dos insetos. Os dados climáticos foram obtidos por meio de registros oficiais disponibilizados no site do Instituto Nacional de Pesquisas Espaciais (www.inpe.br). Constatou-se que, independente da localização da área monitorada, a temperatura e a pluviosidade foram similares [verão $\left(23^{\circ} \mathrm{C} / 15 \mathrm{~mm}\right)$ e outono $\left(18^{\circ} \mathrm{C} / 8 \mathrm{~mm}\right)$ ]. Em Ibiúna, durante o verão, constatou-se uma maior abundância de tripes $(89,7 \%)$ quando comparada com a de afídeos (10,3\%). Em Biritiba-Mirim, observou-se um maior equilíbrio entre as populações de tripes $(55,9 \%)$ e afídeos $(44,1 \%)$. No outono, com o registro de temperaturas mais amenas, as populações de afídeos e tripes foram equivalentes [Biritiba-Mirim $(48,6 \%$ de tripes e $51,4 \%$ de afídeos) e lbíuna (56,6\% de tripes e $43,4 \%$ de afídeos)]. Temperaturas próximas a $25{ }^{\circ} \mathrm{C}$ inibem a indução de formas aladas da maioria das espécies de afídeos e, por outro lado, favorecem a reprodução dos tripes. Índices pluviométricos abaixo de $25 \mathrm{~mm}$ também favorecem as populações desses insetos vetores. Assim, constatou-se que, nas áreas monitoradas, a produção intensiva e diversificada de olerícolas, associada às condições de temperatura e pluviosidade registradas no verão e no outono de 2019 , favoreceram as revoadas de tripes e afídeos e, portanto, foram propícias para a manutenção da pressão de inóculo e dispersão de vírus transmitidos por esses vetores no cinturão verde de São Paulo.

*Financiamento FAPESP (Proc. 2014/22594-2 e 2018/17287-4)

**Bolsista PIBIC/CNPq/IB

${ }^{* * *}$ Bolsista de Doutorado (CAPES)

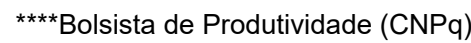


PROPRIEDADES DO EXTRATO INIBIDOR DE INFECÇÃO VIRAL DE Seguieria langsdorffii MOQ. E Pisonia ambigua HEIMERL.* PEREIRA, M.V.M.1**; ALEXANDRE, M.A.V.1; CHAVES, A.L.R.1; SOUZA, A.C.O.2; BERNACCI, L.C.2; DUARTE, L.M.L. ${ }^{1}$ ${ }^{1}$ Instituto Biológico, Av. Cons. Rodrigues Alves, 1252, CEP 04014-900, São Paulo, SP, Brasil. 2Instituto Agronômico de Campinas, Av. Barão de Itapura, 1481, CEP 13020-902, Campinas, SP, Brasil. E-mail: marcosdevone@gmail.com. Properties of the viral infection inhibitor extract from Seguieria langsdorffii Moq. And Pisonia ambigua Heimerl.

Muitos vírus de plantas podem causar perdas em espécies cultivadas de importância econômica, como o Zucchini yellow mosaic virus (ZYMV), gênero Potyvirus), em abobrinhade-moita (Cucurbita pepo 'Caserta'). Apesar da disponibilidade de variedades ou híbridos tolerantes, são recorrentes os relatos do ZYMV em áreas de cultivo de $C$. pepo, causando perdas de até $50 \%$ da produção. No campo, a transmissão é realizada por afídeos vetores de maneira não persistente (durante a picada de prova) e, portanto, o controle por meio da aplicação de inseticida é ineficiente. Desde a década de 1970, medidas alternativas de controle de fitoviroses vêm sendo desenvolvidas no Laboratório de Fitovirologia e Fisiopatologia do Instituto Biológico (LFF/IB), com ênfase na utilização de extratos de espécies de Caryophyllales, devido a sua potente ação inibidora de infecção viral. Recentemente, espécies nativas da Mata Atlântica foram avaliadas e Seguieria langsdorffii (Phytolaccaceae) e Pisonia ambígua (Nyctaginaceae) foram selecionadas, por induzir inibição da infecção em, pelo menos, $80 \%$ das plantas de abobrinha desafiadas pelo ZYMV, após pulverização com extratos foliares de folhas frescas. Com o objetivo de fornecer ao produtor uma forma mais prática de armazenamento, folhas de $S$. langsdorffii e $P$. ambigua foram dessecadas à temperatura ambiente durante dois meses e, em seguida, avaliadas quanto à ação inibidora de infecção pelo ZYMV em C. pepo 'Caserta'. Os extratos aquosos foram preparados a partir de folhas secas, seguindo o mesmo procedimento utilizado para folhas frescas. Além disso, extratos aquosos, obtidos a partir de folhas frescas, mantidos a $-20^{\circ} \mathrm{C}$ e à temperatura ambiente, foram também testados. Verificou-se que, independentemente do preparo, os extratos de $S$. langsdorffii foram os mais eficientes, pois induziram inibição de $100 \%$ da infecção quando mantidos a $-20^{\circ} \mathrm{C}$, por pelo menos 3 anos, e de $90 \%$, quando preparados a partir de folhas secas. O extrato foliar, preparado a partir de folhas de $P$. ambígua dessecadas, induziu inibição de $70 \%$ da infecção quando preparado na diluição de $1 / 40(P / N)$. Por outro lado, quando mantido a $-20{ }^{\circ} \mathrm{C}$, a inibição foi de $50 \%$. Os extratos perderam a atividade inibidora, quando submetidos à temperatura ambiente por 7 dias. Esses resultados fornecem uma nova perspectiva de controle alternativo do ZYMV em abobrinha-de-moita a partir da pulverização de extrato foliar de $S$. langsdorffii obtido de folhas secas preparado na diluição de até 1/160. A utilização desta metodologia permite diminuir os custos com inseticidas, além de não poluir o ambiente.

*Projeto financiado pela FAPESP (Proc. 2016/25708-4)

**Bolsista PIBIC/CNPq/IB 
LEVANTAMENTO E CARACTERIZAÇÃO PARCIAL DOS PRINCIPAIS VÍRUS QUE INFECTAM A CULTURA DO MILHO NO ESTADO DE SÃO PAULO. NASCIMENTO, T.1,2; HARAKAVA, R. ${ }^{1}$; GONÇALVES, M.C. ${ }^{1}$; DUARTE, A.P..$^{3} ;{ }^{1}$ Instituto Biológico, Av. Cons. Rodrigues Alves, 1252, CEP 04014-900, São Paulo, SP, Brasil; ${ }^{2}$ Faculdade Integral Cantareira, São Paulo, SP, Brasil; ${ }^{3}$ Instituto Agronômico de Campinas, Campinas, SP, Brasil. E-mail: thaina-nascimento@outlook.com. Survey and partial characterization of the main viruses infecting corn in the state of São Paulo.

O milho consiste na mais importante cultura dentre os cereais cultivados em território nacional $\mathrm{e}$, atualmente, o Brasil é o $3^{\circ}$ maior produtor mundial. No entanto, o aumento de área plantada e a sobreposição de ciclos da cultura no campo, tem contribuído para o aumento da incidência e severidade de doenças, dentre elas, as doenças virais, como a risca do milho, causada pelo Maize rayado fino vírus (MRFV) transmitido pela cigarrinha do milho (Dalbulus maidis), e o mosaico causado pelo Sugarcane mosaic virus (SCMV), transmitido por várias espécies de afídeos, em especial o pulgão do milho (Rhopalosiphum maidis L.). Além desses vírus, o Maize yellow mosaic virus (MaYMV) foi recentemente relatado no Brasil, também causando sintomas de mosaico e amarelecimento, no entanto, ainda não há informações concretas a sobre seu vetor e a epidemiologia da doença. Há ainda a suspeita de ocorrência do Maize chlorotic mottle virus (MCMV) no país. O presente trabalho teve como objetivo realizar o levantamento dos principais vírus causadores de sintomas severos e perdas na produção de milho no estado de São Paulo. Para isso, nos anos de 2018 e 2019, foram coletadas 122 amostras de milho apresentando diferentes sintomas, provindas de municípios das regiões norte, noroeste, oeste, sudoeste e leste do estado de São Paulo. As amostras foram submetidas a extração de RNA e RT-PCR com primers específicos para SCMV, MRFV, MaYMV e MCMV, visando também o sequenciamento de parte do genoma e proteínas virais chaves. Foram detectados os vírus SCMV, MRFV e MaYMV, e descartada a presença do MCMV. Das 122 amostras, 40 estavam infectadas com SCMV, 55 com MRFV e 81 com MaYMV, sendo que $45 \%$ das amostras analisadas apresentavam infecção mista com dois ou três dos vírus mencionados. Esses resultados explicam os sintomas severos atípicos presentes nas lavouras de milho das principais regiões produtoras do estado. Foram selecionados três isolados para sequenciamento, SCMV Bernardino de Campos (BC), MRFV Manduri (MA) e o MaYMV Mococa (MO), obtendo sequências correspondentes às proteínas $\mathrm{P} 1$ e HCPro, capa proteica (CP) e P2 de cada vírus, respectivamente. A análise filogenética permitiu concluir que, em geral, os isolados apresentaram baixa relação filogenética com os isolados encontrados no "Genbank", sendo que apenas o isolado MRFV MA agrupou-se com isolados brasileiros. Por sua vez, o MaYMV MO mostrou-se mais próximo de outro isolado brasileiro e um do Equador. $\mathrm{O}$ isolado SCMV BC apresentou-se mais próximo filogeneticamente de isolados de países distantes geograficamente do Brasil, especialmente da Ásia. Isso indica uma origem comum com isolados da Ásia, porém também pode ser explicado, em parte, pela ausência no GenBank de sequencias das proteínas P1 e HCPro de outros isolados do Brasil e de outros países da América do Sul.

*Bolsista PIBIC/CNPq 
LEVANTAMENTO DE VÍRUS TRANSMITIDOS POR ÁCAROS Brevipalpus spp. EM ORQUÍDEAS. RODRIGUES, M.C. ${ }^{1,2^{*}}$; POTSCLAM-BARRO, CHABI-JESUS, C. ${ }^{2,4}{ }^{4} .{ }^{2}, 3$; TASSI, A.D. ${ }^{4}$; KITAJIMA, E.W. ${ }^{4}$; RAMOS-GONZÁLEZ, P.L. ; FREITAS-ASTÚA, J. ${ }^{2,5} .{ }^{1}$ Universidade Anhembi Morumbi, SP, Brasil; ${ }^{2} L a b$. Bioquímica Fitopatológica, Instituto Biológico, Av. Conselheiro Rodrigues Alves 1252, CEP 04014-900, São Paulo, SP , Brasil; ${ }^{3}$ Universidade Paulista, SP, Brasil; ${ }^{4}$ Escola Superior de Agricultura Luiz de Queiroz/USP, Piracicaba, SP, Brasil. ${ }^{5}$ Embrapa Mandioca e Fruticultura, Cruz das Almas, Bahia, Brasil. E-mail: macrodrigues12@ gmail.com. Virus lifting transmitted by mites Brevipalpus spp. in orchids.

As orquídeas são plantas ornamentais pertencentes à ordem Asparagales, família Orchidaceae, uma das maiores famílias de plantas existentes. Essas plantas possuem grande valor agregado, ocupando o terceiro lugar em produções de ornamentais no mundo. As orquídeas são acometidas por diversos patógenos, dentre eles, os vírus transmitidos por ácaros do gênero Brevipalpus (VTBs). Os VTBs são filogeneticamente diversos e amplamente classificados de acordo com o local de replicação nas células hospedeiras: no núcleo (VTB-N) ou no citoplasma (VTB-C). Os VTB-N pertencem ao genêro Dichorhavirus, família Rhabidoviridae e os VTB-C estão agrupados dentro dos gêneros Cilevirus e Higrevirus, família Kitaviridae. O orchid fleck virus (OFV) foi o primeiro dichorhavirus caracterizado e infecta naturalmente orquídeas e citros, contudo existem relatos de outros VTB-N e C em orquídeas, mas ainda sem confirmação molecular. Com o intuito de caracterizar a diversidade de VTBs em orquídeas, esse trabalho teve como objetivo realizar um levantamento dos principias VTBs conhecidos em amostras de orquídeas sintomáticas coletadas em Piracicaba, SP. Para tanto, 15 amostras de orquídeas pertecentes aos gêneros: Miltonia, Dendrobium, Brassia, Encyclia, Oncidium, Bulbophyllum, Prosthechea e Angraecum, apresentando sintomas cloróticos e/ou necróticos associados à VTBs foram coletadas no período entre abril e junho de 2019. A detecção dos vírus foi através da microscopia eletrônica de transmissão (MET) e RT-PCR. Na MET, realizada no Laboratório NAP/MEPA, ESALQ, foi direcionado a presença de VTB-N ou C, por meio da localização do viroplasma nas células vegetais. Posteriormente, no Laboratório URL em Biologia Molecular, Instituto Biológico, foi realizada a extração de RNA total mediante o protocolo da Trizol . Os extratos foram submetidos aos testes de RT-PCR (GoScript ${ }^{\mathrm{TM}}$ Reverse Transcriptase e GoTaq ${ }^{\circledR}$ G2 Master Mixes) utilizando iniciadores específicos para a detecção de dichorhavirus (OFV, CICSV, CILSV, CiLV-N) e cilevirus (CiLV-C, CiLV-C2, SvRSV, LigLV, PfGSV), e visualização dos fragmentos obtidos em gel agarose 1\%. Das amostras analisadas, sete delas foram detectadas com a presença de VTBs nucleares e duas com VTB-C. Nos ensaios de RT-PCR, seis amostras foram positivas para OFV e uma positiva para outra espécie de dichoravirus ainda não publicada, com o nome sugerido de clerodendrum leaf spot virus (CILSV) e duas positivas para um cilevirus passion fruit green spot virus (PfGSV). Os resultados demonstram que as orquídeas são hospedeiras naturais de VTBs, não apenas de OFV, que é sempre associado à VTB-N em orquídeas, mas também ao CILSV e ao VTB-C, PfGSV. Novas amostras de diferentes regiões devem ser analisadas para caracterizar a diversidade de VTBs em orquídeas, dando atenção especial ao citoplasmático detectado recentemente. Essas plantas possuem tráfego internacional, e podem funcionar como hospedeiras alternativas de patógenos que podem infectar culturas de importância econômica.

${ }^{*}$ Bolsista CNPq/ Fapesp - Instituto Biológico 
SUSCETIBILIDADE À AZADIRACTINA EM POPULAÇÕES DE Tetranychus urticae (ACARI: TETRANYCHIDAE) PROCEDENTES DE DIFERENTES CULTURAS E REGIÕES BRASILEIRAS.* PEREIRA, E.S.**; MARQUES, S.S. ${ }^{* * *}$; MARÇAL, J.F.**; SATO, M.E. ${ }^{* * * * 1}$ Instituto Biológico, Centro Avançado de Pesquisa em Proteção de Plantas e Saúde Animal, Laboratório de Acarologia, Alameda dos Vidoeiros, 1097, CEP 13101-680,

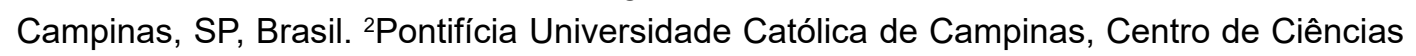
da Vida, Graduação em Ciências Biológicas, Campinas, SP, Brasil. E-mail: elenasartori.p@ gmail.com. Susceptibility to azadirachtin in populations of Tetranychus urticae (Acari: Tetranychidae) from different crops and Brazilian regions.

O ácaro-rajado, Tetranychus urticae Koch (Acari: Tetranychidae), é um dos ácaros-praga de maior importância para a agricultura, causando danos econômicos em um grande número de cultivos agrícolas. O uso frequente de acaricidas para o controle dessa praga tem selecionado populações resistentes aos principais acaricidas registrados no Brasil. Azadiractina é o principal princípio ativo presente no extrato da planta de nim (Azadirachta indica), comumente utilizado para o controle de insetos e ácaros-pragas. $O$ trabalho foi realizado com o objetivo de avaliar a suscetibilidade de diferentes populações de $T$. urticae coletadas em diferentes cultivos e regiões no Brasil. As populações do ácaro-rajado foram coletadas em cultivos comerciais de algodão (Trindade, GO; Primavera do Leste, MT), mamão (Pedreira, SP), morango (Pouso Alegre, MG), jiló (Mogi Guaçu, SP) e tomate (Monte Mor, SP), no período de abril de 2017 a maio de 2018. Após a coleta, os ácaros foram mantidos em plantas de feijão-de-porco, Canavalia ensiformis (L.) DC, em condições de laboratório. As aplicações de azadiractina (Azamax®, 1.2\%) foram realizadas sobre fêmeas adultas de T. urticae, colocadas em arenas de folhas de feijão, em torre de Potter (Burkard Scientific, Uxbridge, UK). Foram utilizadas cinco a oito concentrações do produto, para a obtenção das curvas de concentração-mortalidade e estimativa das concentrações letais $50 \%$ (CL50). Após o tratamento, os ácaros foram mantidos a $25 \pm 1{ }^{\circ} \mathrm{C}, 70 \pm 5 \%$ de umidade relativa e fotofase de $14 \mathrm{~h}$. As avaliações de mortalidade foram conduzidas após 48 e $72 \mathrm{~h}$ da aplicação. As populações de ácaro-rajado apresentaram diferenças significativas na suscetibilidade à azadiractina, com valores de CL50 variando de 48,2 mg i.a./L., para a população mais suscetível (mamão, Pedreira) a $248,6 \mathrm{mg}$ i.a./L, para a população mais resistente (algodão, Primavera do Leste). O valor da CL50 observada para a população de ácaro-rajado de Primavera do Leste foi 8,3 vezes maior que a concentração recomendada do produto para o controle do ácaro-praga no Brasil.

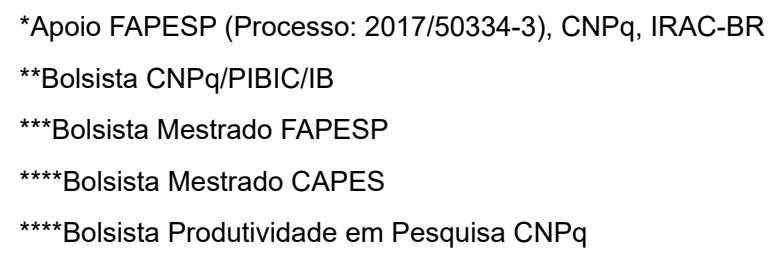


CAPACIDADE DE PREDAÇÃO DE Iphiseiodes matatlanticae MINEIRO, CASTRO \& MORAES (ACARI: PHYTOSEIIDAE) SOBRE OVOS DE Oligonychus ilicis (MCGREGOR) (ACARI: TETRANYCHIDAE)*. LEAL, M.B. ${ }^{1,2 * *}$; MINEIRO, J.L.C. ${ }^{1 * * *}$; SATO, M.E. ${ }^{1 * \star * *}$ ${ }^{1}$ Instituto Biológico, Centro Avançado de Pesquisa em Proteção de Plantas e Saúde Animal/CAPSA, Laboratório de Acarologia, Alameda dos Vidoeiros, 1097, CEP 13101-680, Campinas, SP, Brasil. 'Pontifícia Universidade Católica de Campinas, Centro de Ciências da Vida, Graduação em Ciências Biológicas, Campinas, SP, Brasil. E-mail: lealmarianab@ gmail.com. Predation capacity of Iphiseiodes matatlanticae Mineiro, Castro \& Moraes (Acari: Phytoseiidae) on eggs of Oligonychus ilicis (McGregor) (Acari: Tetranychidae).

O cafeeiro (Coffea arabica L.) é um dos principais cultivos agrícolas no Brasil, gerando renda e trabalho para muitos agricultores. Dentre os ácaros-praga que atacam a cultura, Oligonychus ilicis (McGregor) (Acari: Tetranychidae) é considerado um dos mais importantes no país, causando danos diretos, com destruição de tecido foliar (rompimento de células e perda de clorofila) durante sua alimentação, com consequente perda da capacidade fotossintética, aumento da transpiração e queda precoce de folhas. Iphiseiodes matatlanticae Mineiro, Castro \& Moraes (Acari: Phytoseiidae) é um dos ácaros predadores de maior abundância em cafeeiro (em fragmento florestal) no município de Monte Alegre do Sul, SP. O trabalho foi realizado visando avaliar a capacidade de predação de l. matatlanticae sobre O. ilicis, em condições de laboratório. Foi colocada uma fêmea adulta do ácaro predador por arena de folha de cafeeiro $\left(9 \mathrm{~cm}^{2}\right)$, com diferentes quantidades de ovos do ácaro fitófago, obtendo-se as seguintes proporções de predador por presa: 1:5; 1:10; 1:20 e 1:30. As avaliações foram realizadas diariamente, por um período de seis dias, contando-se os ovos ingeridos pelo predador e substituindo-os por ovos sadios recém-postos do ácaropraga (originários da criação), a cada $24 \mathrm{~h}$, visando manter a mesma densidade inicial de ovos do ácaro-presa. As arenas foram mantidas a $25 \pm 2{ }^{\circ} \mathrm{C}$ e umidade relativa de $70 \pm$ $10 \%$. O experimento foi inteiramente casualizado, com pelo menos cinco repetições. Os dados referentes às primeiras 24 horas dos testes de predação foram descartados devido à possível influência da alimentação prévia do ácaro predador. Os resultados indicam boa capacidade de predação de I. matatlanticae sobre ovos de $O$. ilicis, havendo um consumo de até 12 ovos de O. ilicis por predador por dia. Observou-se aumento na taxa de predação de ovos do ácaro fitófago seguindo o aumento no número de ovos oferecidos.

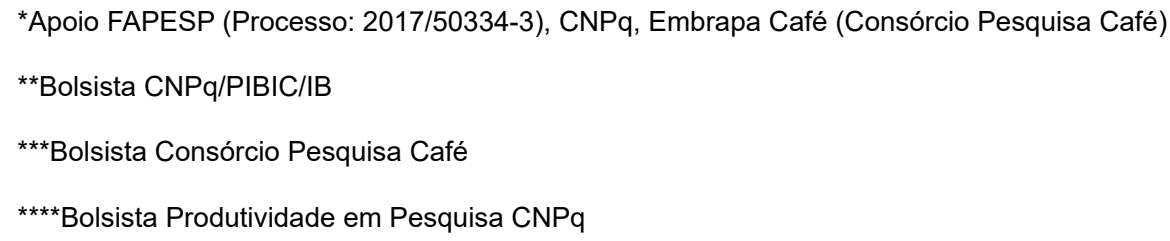


COMPORTAMENTO DE ALIMENTAÇÃO E OVIPOSIÇÃO DO ÁCARO Tetranychus urticae KOCH (ACARI: TETRANYCHIDAE) EM FOLHAS DE DIFERENTES ESPÉCIES DE PLANTAS HOSPEDEIRAS. RODRIGUES, R.M.P. ${ }^{1,2 * *}$; MINEIRO, J.L.C. ${ }^{1 * * *} ;$ SATO, M.E. $1^{* * * *}{ }^{1}$ Instituto Biológico, Centro Avançado de Pesquisa em Proteção de Plantas e Saúde Animal, Laboratório de Acarologia, Alameda dos Vidoeiros, 1097, CEP 13101-680, Campinas, SP, Brasil. 2Pontifícia Universidade Católica de Campinas, Centro de Ciências da Vida, Graduação em Ciências Biológicas, Campinas, SP, Brasil. E-mail: raulmatias.wk@ hotmail.com. Feeding behavior and oviposition of the mite Tetranychus urticae Koch (Acari: Tetranychidae) on leaves of different species of host plants.

O ácaro-rajado, Tetranychus urticae Koch (Acari: Tetranychidae), é considerado um dos ácaros de maior importância em todo o mundo, causando consideráveis prejuízos econômicos em um grande número de culturas agrícolas no Brasil. Há registros do seu ataque em mais de 1.200 espécies de plantas, de 70 gêneros. A pesquisa foi conduzida com o objetivo de observar o comportamento de alimentação, oviposição e produção de teia, do ácaro-rajado, em folhas de singônio (Syngonium podophyllum Schott: Araceae), chuchu (Sechium edule (Jacq.) Sw.: Cucurbitaceae), mamão (Carica papaya L.: Caricaceae) e soja perene [Neonotonia wightii (Wight \& Arn.) J.A. Lackey: Fabaceae], em condições de laboratório. Os ácaros utilizados no experimento foram procedentes de uma população de T. urticae, coletada de cultivo comercial de mamão, no município de Pedreira, SP, em setembro de 2018. Após a coleta, os ácaros foram mantidos em plantas de feijão-deporco Canavalia ensiformis (L.) DC (Fabaceae), em laboratório. Quatro fêmeas adultas de $T$. urticae, de idade uniforme (24 a 48h), foram transferidas para arenas de folha de singônio, chuchu, mamão e soja perene. As avaliações da sobrevivência, oviposição, formação de teia e aspectos visuais dos ovos e formas ativas dos ácaros foram realizadas diariamente, por quatro dias, após a infestação das folhas. O experimento foi inteiramente casualizado, com pelo menos oito repetições. Os dados de oviposição foram submetidos à análise de variância, com comparação das médias pelo teste t a $5 \%$ de significância. Os resultados indicaram diferenças significativas entre as plantas avaliadas, quanto às taxas de oviposição de $T$. urticae, com valores decrescentes para mamão, soja perene, chuchu e singônio. Quando os ácaros foram transferidos para arenas de folha de singônio (Araceae), foram observadas poucas injúrias de alimentação, pouca produção de teia e a mais baixa taxa de oviposição $(0,083$ ovos/fêmea/dia). As formas ativas de T. urticae apresentaram pouca mobilidade e coloração escura, em folhas de singônio. Entretanto, em arenas de folha de mamão, observou-se elevada taxa de oviposição (8,3 ovos/fêmea/dia). Os ácaros apresentaram coloração esverdeada, maior movimentação e alta produção de teia.

\footnotetext{
${ }^{*}$ Apoio FAPESP (Processo: 2017/50334-3), CNPq

**Bolsista CNPq/PIBIC/IB

${ }^{* * *}$ Bolsista Consórcio Pesquisa Café

${ }^{\star * * * B}$ Bolsista Produtividade em Pesquisa CNPq
} 
ANÁLISE DA TOXICIDADE DE dsGFP EM ENSAIOS DE RNA INTERFERENTE (RNAi) APLICADOS AO ÁCARO DA LEPROSE DOS CITROS. FERREIRA, L.M.*; NUNES, M.A.; GALDEANO, D.M.; MACHADO, M.A.; NOVELLI, V.M. IAC, Centro Avançado de Pesquisa de Citros Sylvio Moreira, Rodovia Anhanguera, Km 158, CEP 13490-970, Cordeirópolis, SP, Brasil. E-mail: leticia-m. $@$ @hotmail.com. DsGFP toxicity analysis in RNA interference RNA (RNAi) applied to citrus leprosis mite assays.

A leprose dos citros é uma das principais doenças virais da citricultura, causada pelo Citrus leprosis virus C (CiLV-C, Cilevirus), transmitida por ácaros do gênero Brevipalpus (Tenuipalpidae). Os sintomas da doença nas plantas são caracterizados por lesões locais cloróticas e/ou necróticas em frutos, folhas e ramos, restritas ao sítio de alimentação do vetor, podendo, em estágio avançado da doença, levar à morte da planta. Para controle, o manejo nos pomares é feito primariamente pelo uso de acaricidas, porém com alto custo e potencial risco de prejuízos ambientais. Visando às estratégias de controle mais eficientes e sustentáveis, o uso de técnicas em biologia molecular pode ser uma alternativa para a citricultura. Assim, a tecnologia de RNA interferente (RNAi) no controle de pragas e vetores vem sendo bastante investida para insetos, mas ainda pouco explorada para ácaros. Essa estratégia tem como premissa o silenciamento de genes pela interferência no processo pós-transcricional, desencadeado por pequenos RNAs, impedindo a síntese de proteínas. Buscando avaliar essa técnica e seus efeitos, foram iniciados estudos no CCSM-IAC para o ácaro da leprose $(B$. yothersi). Além das etapas de prospecção e escolha de genes alvos para o silenciamento, é necessário ter controles de dsRNAs (double-stranded RNA) eficientes e que não alterem a biologia do organismo alvo a ser estudado. Para isso, neste trabalho foi avaliada a toxicidade do dsRNA-GFP, comumente utilizado como controle exógeno nos ensaios de RNAi. Nas análises, diferentes concentrações do dsRNA-GFP $(12,5 ; 25 ; 50 ; 75$ e 100ng. $\mu \mathrm{L}-1)$ e água (controle) foram administradas via oral ao ácaro. Fêmeas adultas e sincronizadas do ácaro foram transferidas para discos de papel de filtro, contendo separadamente $30 \mu \mathrm{L}$ de cada concentração, e mantidas para acesso nessas soluções por um período de 5 horas. Após exposição aos dsRNA-GFP, os ácaros foram transferidos para discos foliares de feijoeiro (Phaseolus vulgaris cv. Una) e realizadas as avaliações quanto ao comportamento (fuga), mortalidade e oviposição, em até oito dias pós-tratamento. Foi observado um provável efeito negativo do confinamento dos ácaros nos discos foliares, uma vez que as mortes ocorridas foram por escape (fuga). A relação ovos/fêmea/dia sugeriu que a melhor concentração de dsRNA-GFP foi a de 50ng/ $\mathrm{LL}$, uma vez ter sido a de menor efeito tóxico aos ácaros, quando comparada ao tratamento controle. Concluímos que há um provável efeito do confinamento dos ácaros e que uma menor concentração de dsRNA-GFP tem melhor eficiência para ser usada como controle nos experimentos de RNAi. Estas informações são básicas, mas essenciais aos estudos envolvendo RNAi em ácaros Brevipalpus spp.

Apoio: INCT-Citros 465440/2014-2; FAPESP 2016/21749-8.

*Bolsista CNPq/INCT 
IDENTIFICAÇÃO GENÉRICADE GLYPTOTHRIPINI(THYSANOPTERA: PHLAEOTHRIPIDAE, PHLAEOTHRIPINAE) DE SERAPILHEIRA DO PARQUE ESTADUAL DAS FONTES DO IPIRANGA. MIYASATO, E.A..$^{1,2}$; LIMA, E.F.B. ${ }^{3} ;$ OLIVEIRA, L.A. ${ }^{1,4^{*} ;}$ EIRAS, M..$^{1, * *}$. ${ }^{1}$ Instituto Biológico, Av. Conselheiro Rodrigues Alves 1252, CEP 04014-900, São Paulo, SP; ${ }^{2}$ Instituto Federal Sudeste de Minas Gerais, Campus Barbacena, R. Monsenhor José Augusto 204, CEP 36205-018, Barbacena, MG; '3niversidade Federal do Piauí, Campus Amílcar Ferreira Sobral, BR 343, Km 3,5, CEP 64808-605, Floriano, PI; ${ }^{4}$ Faculdade Cantareira, R. Marcos Arruda, 729, CEP 03020-000, São Paulo, SP; E-mail: elisa.miyasato@ifsudestemg.edu.br. Genus identification of Glyptothripini (Thysanoptera: Phlaeothripidae, Phlaeothripinae) from leaf-litter of the Fontes do Ipiranga State Park.

As espécies de tripes que vivem em serapilheira são em sua maioria micófagas, não atuam diretamente na ciclagem de nutrientes, mas são importantes na regulação das populações de fungos decompositores. A maior diversidade de tripes de serapillheira no mundo foi coletada na Mata Atlântica, no distrito de Nova Teutônia, Seara, Santa Catarina. Essas espécies pertencem especialmente à tribo Glyptothripini (Thysanoptera: Phlaeothripidae, Phlaeothripinae) que, embora não bem definida morfologicamente, agrupa tripes de serapilheira com esculturações reticuladas externas. O Parque Estadual Fontes do Ipiranga (PEFI), localizado no município de São Paulo, é um remanescente de Mata Atlântica e deve abrigar uma grande diversidade deste grupo de tripes ainda pouco conhecido no Brasil, incluindo o estado de São Paulo. Portanto, este trabalho teve como objetivo identificar os gêneros da tribo Glyptothripini coletados em serapilheira do PEFI. As coletas de serapilheira foram realizadas de fevereiro a maio de 2019 , em duas áreas do PEFI, caracterizadas de acordo com os graus de perturbação menor (1) e intermediário (2). Cada área foi subdividida em 24 parcelas de $10 \times 10 \mathrm{~m}$, sendo 2 parcelas sorteadas para coletas mensais de 5 amostras de serapilheira, utilizando como gabarito um quadrado de $50 \mathrm{~cm}$ de lado. As amostras foram transferidas para funis de Berlese para obtenção dos tripes. Estes foram montados em lâminas permanentes em meio bálsamo do Canadá, e identificados utilizando literatura disponível. Foram triados, no total, 169 espécimes de tripes adultos e 58 imaturos, sendo 96 adultos pertencentes à tribo Glyptothripini. Os espécimes de Glyptothripini foram separados em 12 morfoespécies (Chtonothrips sp. 1, Chtonothrips sp. 2, Eschatothrips sp., Glyptothrips sp., Glyptothripini sp. 1, Glyptothripini sp. 2, Orthothrips sp. 1, Orthothrips sp. 2, Terthrothrips sp. 1, Terthrothrips sp. 2 e Tylothrips sp.). O resultado com pouca especificidade reflete a dificuldade na identificação desse grupo. Eurythrips apresenta apenas um caráter diagnóstico e Glyptothrips e Terthothrips apresentam espécies com características intermediárias. O mesmo problema ocorre na identificação entre Glyptothrips, Eschatothrips e Orthothrips e também entre Glyptothrips e Tylothrips. Todos os espécimes foram coletados na área 1, exceto Glyptothripini sp.1, que foi coletado apenas na área 2. Um número maior de coletas será necessário para comparar a diversidade entre as duas áreas. Espera- se que a caracterização morfológica das populações de diferentes ambientes e estudos com uma abordagem molecular possam contribuir para identificação e análises filogenéticas de Glyptothripini.

${ }^{*}$ Bolsista CNPq/PIBIC/IB

**Bolsista de produtividade do CNPq 


\begin{abstract}
INSETOS (ARTHROPODA, HEXAPODA, INSECTA) COLETADOS EM BACIA HIDROGRÁFICA DE SAPUCAÍ-MIRIM/MG PARA O PROJETO "ÁGUAS DA MANTIQUEIRA": PRIMEIRA APROXIMAÇÃO. ${ }^{*}$ TEIXEIRA, I.N. ${ }^{1,2}$; FRANCO, K.P.A.C. ${ }^{1} ;$ YAMAKAWA, W. ${ }^{3}$; IDE, S. ${ }^{1}{ }^{1}$ Instituto Biológico, Laboratório de Entomologia Geral, Avenida Conselheiro Rodrigues Alves, 1252, CEP 04014-900, São Paulo, SP, Brasil. 'Universidade Paulista, Curso de Ciências Biológicas, Instituto de Ciências da Saúde, São Paulo, SP, Brasil. "Projeto "Águas da Mantiqueira", São Bento do Sapucaí, SP, Brasil. E-mail: nobregaingred@gmail.com. Insects (Arthropoda, Hexapoda, Insecta) collected in watershed at Sapucaí-Mirim/MG for the project "Águas da Mantiqueira": First approach.
\end{abstract}

O Projeto "Águas da Mantiqueira" objetiva conhecer e mensurar a diversidade de insetos (Arthropoda, Hexapoda, Insecta), peixes (Osteichthyes), anfíbios (Amphibia), aves (Reptiliomorpha), mamíferos (Mammalia) (Chordata, Vertebrata) e flora da Serra da Mantiqueira, com vistas à proposição de medidas de conservação e elaboração dos planos diretores dos municípios da região. A unidade de área adotada para o levantamento é a bacia hidrográfica. No período de XI.2018 a III.2019 foram efetuadas 15 coletas de insetos na bacia do Ribeirão Juncal, Sapucaí-Mirim/MG. As coletas foram manuais e com o uso de guarda-chuva, rede e pinça; os espécimes foram mantidos em etanol $70 \%$ ou envelopes entomológicos e encaminhados ao Laboratório de Entomologia Geral, Instituto Biológico, São Paulo, para montagem, rotulagem e identificação. Os exemplares foram separados em ordens, famílias ou subfamílias e morfoespécies. Foram coletados 411 espécimes e as seguintes morfoespécies foram reconhecidas ([ORDEM] - [FAMÍLIA] [Subfamília]: número de morfoespécies (morfoespécie / número de indivíduos)): [ODONATA] - [AESHNIDAE]: 01 (03), [CALOPTERYGIDAE]: 04 (01 / 02, 02 / 02, 03 / 03, 04 / 01), [COENAGRIONIDAE]: 02 (01 / 01, 02 / 06), [CORDULIIDAE]: 01 (01) e [LIBELLULIDAE]: 01 (03); [BLATTODEA] - [BLATTELLIDAE]: 01 (01) e [BLATTIDAE]: 01 (01); [HEMIPTERA] - [BELOSTOMATIDAE]: 01 (01), [CICADELLIDAE]: 01 (01), [COREIDAE]: 01 (01), [CYDNIDAE]: 01 (12), [LARGIDAE]: 02 (01 / 03, 02 / 01), [LYGAEIDAE]: 01 (01), [MIRIDAE]: 01 (01), [NEPIDAE]: 01 (01), [PENTATOMIDAE]: 03 (01 / 03, 02 / 01, 03 / 01) e [REDUVIIDAE]: 04 (01 / 02, 02 / 02, 03 / 02, 04 / 01); [MEGALOPTERA] - [CORYDALIDAE]: 01 (01); [COLEOPTERA] [CANTHARIDAE]: 04 (01 / 02, 02 / 01, 03 / 01, 04 / 01), [CARABIDAE]: 01 (01), [CERAMBYCIDAE]: 05 (01 / 02, 02 / 01, 03 / 01, 04 / 01, 05 / 01), [CHRYSOMELIDAE] [Cassidinae]: 04 (01 / 11, 02 / 03, 03 / 03, 04 / 01), [Chrysomelinae]: 05 (01 / 09, 02 / 08, 03 / 03, 04 / 01, 05 / 01), [Cryptocephalinae]: 01 (01), [Donaciinae]: 03 (01 / 01, 02 / 01, 03 / 03), [Eumolpinae]: 09 (01 / 19, 02 / 10, 03 / 08, 04 / 07, 05 / 02, 06 / 01, 07 / 01, 08 / 01, 09 / 01) e [Galerucinae]: 05 (01 / 21, 02 / 04, 03 / 02, 04 / 02, 05 / 01), [COCCINELLIDAE]: 04 (01 / 05, 02 / 02, 03 / 02, 04 / 01), [CURCULIONIDAE]: 08 (01 / 11, 02 / 04, 03 / 02, 04 / 02, 05 / 01, 06 / 01, 07 / 01, 08 / 01), [DERMESTIDAE]: 01 (01), [DRYOPIDAE]: 01 (07), [ELATERIDAE]: 03 (01 / 02, 02 / 01, 03 / 01), [ENDOMYCHIDAE]: 01 (02), [EROTYLIDAE]: 01 (01), [GYRINIDAE]: 01 (09), [LAMPYRIDAE]: 02 (01 / 02, 02 / 01), [LYCIDAE]: 01 (02), [MELYRIDAE]: 02 (01 / 01, 02 / 01) [NITIDULIDAE]: 01 (01), [OEDEMERIDAE]: 01 (01), [PASSALIDAE]: 01 (01), [SCARABAEIDAE] [Aphodiinae]: 02 (01 / 04, 02 / 05), [Cetoniinae]: 01 (02), [Dynastinae]: 05 (01 / 07, 02 / 05, 03 / 04, 04 / 01, 05 / 01), [Melolonthinae]: 01 (05), [Rutelinae]: 02 (01 / 07, 02 / 01), [Scarabaeinae]: 04 (01/ 07, 02 / 05, 03 / 05, 04 / 01), [STAPHYLINIDAE]: 01 (02), [TENEBRIONIDAE]: 07 (01 / 02, 02 / 02, 03 / 01, 04 / 01, 05 / 01, 06 / 01, 07 / 01) e [TROGOSSITIDAE]: 01 (01); [DIPTERA] - [SARCOPHAGIDAE]: 01 (01), [TACHINIDAE]: 03 (01 / 03 , 02 / 02, 03 / 02) e [CALLIPHORIDADE]: 01 (01); [LEPIDOPTERA] - [HESPERIIDAE] [Hesperiinae]: 01 (01) e [Pyrginae]: 01 (02), [NYMPHALIDAE] [Biblidinae]: 01 (01), [Danainae]: 01 (01), [Heliconiinae]: 03 (01 / 01, 02 / 01, 03 / 01), [Ithomiinae]: 04 (01 / 04, 02 / 02, 03 / 01, 04 / 01), [Limenitidinae]: 01 (04), [Nymphalinae]: 01 (02) e [Satyrinae]: 01 (02), [PIERIDAE] [Pierinae]: 03 (01 / 01, 02 / 01, 03 / 01), [PAPILIONIDAE] [Papilioninae]: 01 (01) e [SATURNIIDAE]: 01 (01); [HYMENOPTERA] - [APIDAE]: 10 (01 / 19, 02 / 04, 03 / 03, 04 / 01, 05 / 01, 06 / 01, 07 / 01, 08 / 01, 09 / 01, 10 / 01), [BETHYLIDAE]: 01 (01), [ICHNEUMONIDAE]: 02 (01 / 03, 02 / 01) e [THIPIIDAE]: 01 (01).

*Financiamento: Fundação Toyota do Brasil 
DESCRIÇÃO DOS IMATUROS E ASPECTOS DA BIOLOGIA DE Psyllobora distinguenda (CROTCH, 1874) (INSECTA, COLEOPTERA, COCCINELLIDAE, COCCINELLINAE). FRANCO, K.P.A.C. ${ }^{1,2 *}$; TEIXEIRA, I.N. ${ }^{1,3}$; IDE, S. ${ }^{1}{ }^{1}$ Instituto Biológico, Laboratório de Entomologia Geral, Avenida Conselheiro Rodrigues Alves, 1252, CEP 04014-900, São Paulo, SP, Brasil. ${ }^{2}$ Universidade Presbiteriana Mackenzie, Centro de Ciências Biológicas

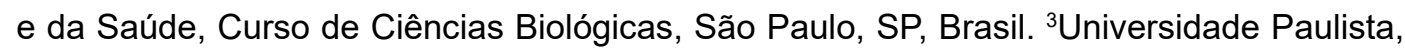
Instituto de Ciências da Saúde, Curso de Ciências Biológicas, São Paulo, SP, Brasil. E-mail: kayhecury@gmail.com. Description of immatures and aspects of biology of Psyllobora distinguenda (Crotch, 1874) (Insecta, Coleoptera, Coccinellidae, Coccinellinae).

O gênero Psyllobora Dejean, 1836 (Insecta, Coleoptera, Coccinellidae, Coccinellinae) está incluído no grupo de besouros popularmente conhecidos como joaninhas. Diferentemente de muitas espécies de Coccinellidae, não apresenta hábitos de predação, mas praticam micofagia, consumindo fungos, em especial do grupo dos oídios (Erysiphaceae) causadores de danos a diversas espécies de plantas. Adultos podem variar seu tamanho de 1,8 a $6,5 \mathrm{~mm}$, apresentam coloração amarelo-clara com manchas marrons no pronoto e élitros; larvas com coloração predominante creme e podem chegar a 0,6 $\mathrm{mm}$ de comprimento e $0,2 \mathrm{~mm}$ de largura. Em levantamento prévio, observou-se a presença de representantes desse gênero alimentando-se do fungo Ovulariopsis Pat. \& Har. (Erysiphaceae) em folhas de amoreira (Morus nigra L.) (Moraceae). Devido à importância fitopatogênica do fungo e relevância do controle biológico, iniciou-se o projeto de conhecimento morfológico das fases imaturas desses animais. De maio a setembro de 2018 , foram realizadas 40 coletas, e nelas observados espécimes de três espécies de Psyllobora. Dentre estas, foi identificada a presença de $P$. distinguenda (Crotch, 1845) escolhida para ser alvo do estudo. Para a espécie estudada, a emergência do ovo ocorreu em aproximadamente 8 dias, a duração (dias) das larvas instares foi: I - 5-6, II - 5-6, III - 5-6 e o período de pupa foi de aproximadamente 7 dias. As larvas de $P$. distinguenda são campodeiformes, amareloclaras, com tamanho de 5,0 a 6,0 mm. Cabeça prognata, ligeiramente coberta por cerdas e três pares de estemas bem desenvolvidos lateralmente; antenas curtas e bissegmentadas. Protórax mais estreito que o meso e metatórax, e estes apresentam par de protuberâncias pilosas nas laterais. Pronoto mais largo que longo, contorno aproximadamente elíptico; com par de áreas esclerotizadas contornadas por cerdas, par de tubérculos castanhos ou acinzentados guarnecidos na região mesobasal. Meso e metanoto transversos; par de áreas esclerotizadas castanho-claras com as bordas elevadas e margeadas por cerdas ocupando a região mediana, regiões laterais das áreas esclerotizadas intumescidas Pernas longas, aproximadamente do mesmo comprimento; segmentos cilíndricos; tibiotarso com numerosas cerdas afiladas, área apical adjacente ao pretarso, densamente revestida por cerdas com ápice expandido; pretarso bifurcado, base larga. Abdômen com segmentos visíveis dorsalmente, com dois pares de tubérculos pilosos cada, cerdas eretas; órgãos adesivos presentes no último segmento. Peças bucais relativamente bem desenvolvidas em relação aos hábitos alimentares. Pupas exaratas, adécticas, com manchas dorsais similares às dos adultos de 4,0 a 5,0 mm de comprimento.

*Bolsista CNPq/PIBIC/IB 
MOSCAS-DAS-FRUTAS (DIPTERA: TEPHRITIDAE, LONCHAEIDAE) E SUAS PLANTAS HOSPEDEIRAS NO ESTADO DE SÃO PAULO. LIMA, G. ${ }^{*}$; CRUZ, B.S. *1; SOUZA-FILHO, M.F. ${ }^{2}$; LOUZEIRO, L.R.F. ${ }^{* * 2}$; RAGA, A. ${ }^{2} ;{ }^{1}$ Pontifícia Universidade Católica de Campinas, Faculdade de Ciências Biológicas, Campinas, SP, Brasil; ${ }^{2}$ Instituto Biológico, Centro Avançado de Pesquisa em Proteção de Plantas e Saúde Animal/CAPSA, Alameda dos Vidoeiros, 1097, CEP 13101-680, Campinas, SP, Brasil, Caixa Postal 70, CEP 13012970, Campinas, SP, Brasil. E-mail: gabrielaa.lima0206@gmail.com. Fruit flies (Diptera: Tephritidae, Lonchaeidae) and their host plants in the State of São Paulo, Brazil.

As moscas-das-frutas (Diptera: Tephritidae) são consideradas as principais pragas que afetam a fruticultura devido aos danos diretos que causam e a capacidade de adaptar-se em outras regiões. O Brasil por estar localizado na região neotropical e possuir dimensão continental encontra dificuldades em estabelecer estratégias de controle de pragas, uma vez que os problemas fitossanitários são distintos de uma região para outra. O projeto teve por objetivo estudar e contribuir para o conhecimento da composição de espécies de (Diptera: Tephritidae) e a sua infestação natural no estado de São Paulo. Foram realizadas coletas de frutos tanto na área rural quanto na área urbana aleatoriamente. As amostras de frutos coletadas foram levadas ao laboratório onde cada amostra de cada espécie frutífera foi pesada, o seu número de frutos contados, acondicionadas em caixas plásticas contendo uma camada vermiculita ao fundo e depois cobertas com tecido. Cada amostra recebeu uma etiqueta de identificação com anotações dos dados de coletas ( $n^{\circ}$ da amostra, nome da planta, data, local de coleta, coordenadas geográficas, peso, $\mathrm{n}^{\mathrm{o}}$ de frutos e coletor). Decorridos alguns dias após a coleta, o substrato foi peneirado, sendo que as pupas obtidas foram contadas e colocadas em recipientes de vidro contendo vermiculita e em seguida foram acondicionadas no interior de cubas de vidro para permitir a emergência dos adultos de moscas-das-frutas. Após a emergência dos adultos, os mesmos foram mortos, separados por sexo, contados e acondicionados em frascos contendo álcool. Foram realizadas 85 coletas abrangendo sete municípios durante o período de agosto de 2018 até de julho de 2019. Foram coletadas 49 espécies botânicas (considerando espécies, cultivares e híbridos) pertencentes a 21 famílias. Ao todo foram recuperados 2.450 exemplares de tefritídeos sendo 1.443 adultos de Anastrepha e 1.027 adultos de Ceratitis capitata. Quanto aos lonqueídeos foram obtidos apenas 190 adultos. Os exemplares de Anastrepha ainda não foram identificados até o momento. Psidium guajava L. (goiaba) foi a frutífera que apresentou maior número de moscas emergidas obtidas totalizando 953 adultos representados por 495 exemplares de Anastrepha e 458 exemplares de $C$. capitata. Considerando-se o índice de infestação por fruto a espécie Acca sellowiana (O. Berg) Burret (goiaba-serrana) (Myrtaceae) apresentou o valor de 16,16 pupários/fruto e o maior índice de infestação por peso de fruto, foi da espécie Eugenia pyriformis Cambess (uvaia) (Myrtaceae) com 647,58 pupários/kg de frutos.

* Bolsista CNPq / PIBIC / IB.

** Bolsista CAPES / Doutorado 
PARASITOIDES (HYMENOPTERA: BRACONIDAE E FIGITIDAE) ASSOCIADOS À MOSCAS-DAS-FRUTAS (DIPTERA: TEPHRITIDAE) NO ESTADO DE SÃO PAULO. CRUZ, B.S. ${ }^{* 1}$; LIMA, G. ${ }^{* 1}$; SOUZA-FILHO, M.F. $;$; LOUZEIRO, L.R.F. ${ }^{* * 2}$; RAGA, A. ${ }^{2}{ }^{1}$ Pontifícia Universidade Católica de Campinas, Faculdade de Ciências Biológicas, Campinas, SP, Brasil. ${ }^{2}$ Instituto Biológico, Centro Avançado de Pesquisa em Proteção de Plantas e Saúde Animal/CAPSA, Alameda dos Vidoeiros, 1097, CEP 13101-680, Caixa Postal 70, Campinas, SP, Brasil. E-mail: beatrizscruz1@gmail.com. Parasitoids (Hymenoptera: Braconidae and Figitidae) associated with fruit flies (Diptera: Tephritidae) in São Paulo State, Brazil.

O controle biológico natural é um importante regulador das populações de moscasdas-frutas (Diptera: Tephritidae) contribuindo como uma excelente alternativa dentro do manejo integrado. As moscas-das-frutas são as mais importantes pragas que afetam a produção comercial de frutas no Brasil, onde o maior número de espécies de himenópteros parasitoides pertence às famílias Braconidae e Figitidae. O projeto teve por objetivo estudar e contribuir para o conhecimento da diversidade de espécies de parasitoides de moscasdas-frutas no estado de São Paulo e os aspectos ecológicos envolvidos no seu parasitismo. Foram realizadas amostragens de frutos aleatoriamente em sete municípios do estado de São Paulo, abrangendo área rural e área urbana, durante o período de agosto de 2018 a julho de 2019. No laboratório, os frutos foram contados, pesados e colocados em bandejas plásticas contendo vermiculita ao fundo e fechadas com tecido. Cada amostra recebeu uma etiqueta de identificação com anotações dos dados de coletas ( $\mathrm{n}^{\circ}$ da amostra, nome da planta, data, local de coleta, coordenadas geográficas, peso, nó de frutos e coletor). Decorridos alguns dias após a coleta, a vermiculita foi peneirada para a obtenção dos pupários de moscas-das-frutas, que em seguida foram contados e colocados em recipientes de vidro contendo vermiculita, e que depois foram acondicionados no interior de cubas de vidro para permitir a emergência dos adultos (moscas e parasitoides). Emergiram 563 parasitoides pertencentes às famílias Braconidae (459) e Figitidae (104). O parasitismo máximo foi de $80 \%$ nas pupas de moscas-das-frutas em frutos de uvaia (Eugenia pyriformis Cambess.) (Myrtaceae) e o menor foi de 1,58\% em araticum (Annona sp.) (Annonaceae). As taxas de parasitismo variaram de $1,58 \%$ a $80 \%$, com média de $23,38 \%$. As espécies de braconídeos obtidas foram: Asobara anastrephae, Doryctobracon areolatus, $D$. brasiliensis, Opius bellus e Utetes anastrephae. Doryctobracon areolatus, até o momento, foi a espécie mais abundante e de maior distribuição no estado de São Paulo. As maiores taxas de parasitismo ocorreram em frutos pequenos, que apresentaram proporcionalmente os mais altos índices de infestação por moscas-das-frutas.

*Bolsista CNPq/PIBIC/IB

**Bolsista CAPES/Doutorado 


\begin{abstract}
AVALIAÇÃO DOS FILTRADOS DE BACTÉRIAS SIMBIONTES DE NEMATOIDES ENTOMOPATOGÊNICOS NO MANEJO DE Sclerotinia sclerotiorum E Neofusicoccum parvum. FERREIRA, N.*; LEITE, L.G.; CHACÓN-OROZCO, J.; OTOYA-MARTINEZ, N.; BUENO, C.J. Instituto Biológico, Centro Avançado de Pesquisa em Proteção de Plantas e Saúde Animal - CAPPSA, Laboratório de Controle Biológico, Rua dos Vidoeiros, 1097, CEP 13101-680, Campinas, SP, Brasil. E-mail: nattferreira1@gmail.com. Evaluation of entomopathogenic nematoid symbiotic bacteria filtrates in the management of Sclerotinia sclerotiorum and Neofusicoccum parvum.
\end{abstract}

Os nematoides entomopatogênicos (NEPs), principalmente os pertencentes aos gêneros Steinernema e Heterorhabditis, são constantemente utilizados como agentes para o controle biológico de uma variedade muito grande de insetos-pragas presentes na agricultura. Ambos os nematoides apresentam uma associação simbiótica com dois gêneros de bactérias, sendo que Steinernema tem associação com a bactéria do gênero Xenorhabdus e Heterorhabditis, com a bactéria do gênero Photorhabdus. As bactérias simbiontes são responsáveis pela produção de metabólitos secundários que são encarregados da morte dos insetos-pragas e também estão associados com a inibição do crescimento micelial de uma variedade de fungos. O principal objetivo do presente trabalho foi verificar a inibição do crescimento do micélio de dois fungos fitopatogênicos (Sclerotinia sclerotiorum e Neofusicoccum parvum), a partir da utilização dos metabólitos secundários produzidos pelas bactérias simbiontes de NEPs. Para obter os metabólitos secundários livres de células, foram isoladas 21 bactérias presentes nos nematoides a partir da inoculação destes em lagartas de segundo instar de Galleria mellonella plaqueadas em um meio de cultura NBTA. Também foi necessário realizar a repicagem dos fungos fitopatogênicos em meios BDA. No entanto, S. sclerotiorum apresenta estruturas denominadas de escleródios, os quais foram utilizados para realizar a repicagem, diferente de N. parvum, que já havia sido isolado, e pequenos discos foram colocados em novas placas com meio de cultura BDA. Esses isolados bacterianos foram filtrados e incorporados a novos meios de cultura BDA a uma concentração de 10\%, e para avaliar a inibição do crescimento micelial, discos de BDA contendo os fungos fitopatogênicos foram colocados no centro de cada uma das placas. Para a realização desse experimento, foram necessárias três fases para facilitar a observação dos resultados, utilizando-se sete bactérias a cada fase desse experimento. Ambos os fungos foram afetados pelos filtrados das bactérias, porém foi possível observar nos resultados obtidos que o fungo $S$. sclerotiorum foi mais suscetível à ação dos metabólitos (atingindo a inibição máxima de 100\%) em comparação com N. parvum, o qual atingiu inibição máxima de $93,9 \%$. Em cada uma das etapas realizadas durante o experimento houve uma bactéria com melhor desempenho com relação à inibição do crescimento micelial. Porém, ao final, foi possível constatar que em ambos os fungos, os isolados PAM 25 e PAM 11 foram os que desempenharam melhor resultado na inibição do crescimento dos fungos. Além disso, o desempenho dos metabólitos secundários em cada um dos fungos utilizados se apresenta de maneira diferente, devido às propriedades químicas diferentes entre as bactérias de cada tipo de isolado e, também, devido às características dos fungos. O estudo sugere, ainda, a possibilidade de uso dessas bactérias como agentes biológicos potenciais no manejo de doenças nas plantas e principalmente agentes biológicos contra os fungos fitopatogênicos.

${ }^{*}$ Bolsista CNPq/PIBIC/IB 
TENTATIVAS DE DIFERENCIAÇÃO DE Xanthomonas spp. CAUSADORAS DA MANCHA BACTERIANA DO TOMATEIRO POR TÉCNICAS SEROLÓGICAS. GOMES, C.G. ${ }^{*}$; BERIAM, L.O.S. * ${ }^{1}$ Pontifícia Universidade Católica de Campinas, Faculdade de Ciências Biológicas, Campinas, SP, Brasil. Instituto Biológico, Centro Avançado de Pesquisa em Proteção de Plantas e Saúde Animal - CAPSA, CP 70, CEP 13012-970, Campinas, SP, Brasil. E-mail: carolina.grava@hotmail.com. Attempts to differentiate Xanthomonas spp. the causal agent of tomato bacterial spot by serological techniques.

A "mancha bacteriana" do tomateiro é uma das principais doenças bacterianas da cultura. O agente causal dessa doença foi por muito tempo atribuído a uma única bactéria Xantomonas campestris pv. vesicatoria. Com o advento das técnicas de biologia molecular, essa espécie foi desmembrada em quatro novas espécies: Xanthomonas euvesicatoria, $X$. perforans, $X$. vesicatoria e $X$. gardnerii. Do ponto de vista prático, essa divisão tem causado confusão e dificultado a diagnose. Consequentemente, também tem dificultado a adoção de medidas de controle da doença, pois pelas técnicas clássicas de Fitobacteriologia Isolamento, testes fisiológicos e bioquímicos - não é possível identificar qual espécie de Xanthomonas é patogênica ao tomateiro. As espécies bacterianas do gênero Xanthomonas (vesicatoria, euvesicatoria, perforans e gardnerii) que são patogênicas ao tomateiro atualmente só são diferenciadas por técnicas de biologia molecular, utilizando primers específicos para cada uma das espécies. No presente projeto, foram iniciados experimentos visando à diferenciação dessas quatro espécies por técnicas serológicas de dupla difusão em ágar (dda), com a utilização de antissoros específicos para cada uma dessas espécies bacterianas. Foram utilizados testes de dda em quatro meios suportes diferentes, utilizando antígenos na forma de suspensão bacteriana em solução salina de 19 isolados de Xanthomonas sp. e antissoros produzidos contra linhagens de Xanthomonas (vesicatoria, perforans e gardnerii), a partir de antígenos extraídos do complexo proteico da membrana (CPM). Após os testes com CPM, foram realizados novos testes utilizando glicoproteínas extraídas da cápsula bacteriana. Ambos os testes não permitiram a diferenciação dos isolados de Xanthomonas ao nível de espécie.

*Bolsista CNPq/PIBIC/IB 
CARACTERIZAÇÃO DE LINHAGENS DE Pseudomonas ISOLADAS DO CAFEEIRO. BUENO, B.I.*; DESTEFANO, S.A.L. Instituto Biológico, Centro Avançado de Pesquisa em Proteção de Plantas e Saúde Animal/CAPSA, Alameda dos Vidoeiros, 1097, Sítios de Recreio Gramado, Cep 13101-680, Campinas, SP, Brasil. E-mail: brunaisabelebueno@ outlook.com. Characterization of Pseudomonas strains isolated from coffee.

A cafeicultura é uma importante fonte de receita para diversos países e o Brasil é um dos principais produtores e exportadores desse produto, movimentando bilhões de dólares anualmente, gerando fontes de renda para municípios e emprego para a população. As pesquisas sobre essa cultura têm buscado minimizar as perdas na produção, associadas a pragas e doenças. No Brasil, dentre as principais doenças responsáveis pela redução na produção de café, encontramos as doenças bacterianas denominadas: mancha aureolada, causada por Pseudomonas syringae pv. garcae e mancha foliar bacteriana, causada por Pseudomonas syringae pv. tabaci. O diagnóstico dessas doenças é bastante difícil, uma vez que os agentes causais apresentam características morfológicas muito semelhantes, havendo necessidade da realização de testes bioquímicos ou moleculares para a correta identificação. O presente estudo teve por objetivo identificar 109 linhagens isoladas de cafeeiro, de diferentes regiões produtoras do país, por meio da utilização de primers específicos. Nas amplificações foi utilizado o par de primers Psg3F/rpoDR, com fragmento esperado de 275 pares de bases (pb), para a identificação de $P$. syringae pv. garcae e Pst3F/rpoDR, com fragmento de 585 pb, para $P$. syringae pv. tabaci. Das 109 linhagens analisadas, 75 foram identificadas como $P$. syringae pv. garcae e 34 como $P$. syringae pv. tabaci. Todas as linhagens estão depositadas na Coleção de Culturas de Fitobactérias do Instituto Biológico (IBSBF).

*Bolsista - CNPq/PIBIC/IB 
EFEITO DE DIVERSOS PRODUTOS SOBRE A MANCHA AUREOLADA DO CAFEEIRO, CAUSADA POR Pseudomonas syringae pv. garcae. BEZERRA, L.S.*; FONSECA, G.A.; DEUS, B.C.; PATRÍCIO, F.R.A. Instituto Biológico, Centro Avançado de Pesquisa em Proteção de Plantas e Saúde Animal - CAPSA, Alameda dos Vidoeiros, 1097, Bairro Gramado, CEP 13.101-680, Campinas, SP, Brasil. E-mail: luckbzha@gmail.com. Effect of resistance inductors on bacterial blight of coffee, caused by Pseudomonas syringae pv. garcae.

A mancha aureolada, causada por Pseudomonas syringae pv. garcae, é uma importante doença do cafeeiro, especialmente em locais sujeitos à incidência de ventos. O manejo dessa doença é complexo e, além do plantio de quebra-ventos e eliminação de mudas doentes, geralmente é efetuado com fungicidas cúpricos. Outros produtos como antibióticos, também podem ser utilizados no controle da mancha aureolada. Este estudo teve como objetivo avaliar produtos indutores de resistência in vitro e em mudas de cafeeiro da cultivar Mundo Novo. Os produtos - Vantocil (polyhexamethylene biguanide hydrochloride); ADM0051; NHT cobre; Difere; Casugamicida e um combinado da Casugamicina com o

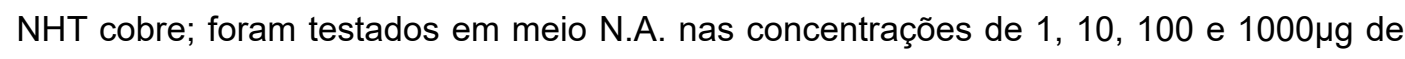
ingrediente ativo (i.a.) por litro de meio, com relação à inibição da formação de colônias dos isolados IBSBF 1664 e IBSBF 2840 de Pseudomonas syringae pv. garcae. Em mudas de cafeeiro da cultivar Mundo Novo foram realizados experimentos. No primeiro, os indutores foram colocados no substrato uma semana antes da inoculação e, no segundo, a parte aérea das mudas foi tratada um dia antes da inoculação. As mudas foram inoculadas com uma suspensão contendo 108 unidades formadoras de colônias (UFC) ml-1 dos isolados de $P$. syringae pv. garcae. utilizados nos experimentos in vitro. Nos experimentos in vitro, observou-se inibição total na formação de colônias na concentração de $1000 \mu \mathrm{g}$ de i.a. por litro de meio nos tratamentos com Casugamicina. No experimento com mudas em que os produtos foram aplicados na parte foliar os tratamentos com ADM0051; Difere; NHT cobre e a Casugamicida reduziram a severidade da mancha aureolada, e os tratamentos com NHT cobre e com Casugamicida mantiveram o maior número de folhas no final do experimento. Os resultados indicam que os indutores de resistência deverão ser testados como alternativa para o manejo da mancha aureolada em condições de campo.

*Bolsista CNPq/PIBIC/IB 
AVALIAÇÃO DA SENSIBILIDADE DAS CULTURAS DE SOJA E FEIJÃO SUBMETIDAS A HERBICIDA RESIDUAL. MONTEIRO, T.S.F.*; BLANCO, F. M.G; OLIVEIRA, E.T; Instituto Biológico, Centro Avançado de Pesquisa em Proteção de Plantas e Saúde Animal - CAPPSA, Laboratório da Ciência das Plantas Daninhas, Rua dos Vidoeiros, 1097, CEP 13101-680, Campinas, SP. Email: thais.sfm@outlook.com. Evaluation of sensitivity of soybean and bean crops submitted to residual herbicide

As plantas daninhas prejudicam economicamente as culturas agrícolas, o método de controle mais utilizado em áreas de agricultura extensiva é o químico, com uso de herbicidas, dentre estes aqueles que são residuais (pré-emergentes) aplicados diretamente sobre o solo. Muitos podem apresentar com longa persistência no solo, como é o caso do herbicida indaziflam. Desta forma, é interessante avaliar a sensibilidade de culturas em sucessão em áreas em que foram utilizados este herbicida, que pode apresentar níveis residuais no solo por um período além do desejável, passível de causar injuria a estas culturas. Foi realizado ensaios para avaliar a sensibilidade das culturas Soja BMX Potência RR (Glycine max) e Feijão Formoso (Phaseolus vulgaris) ao herbicida indaziflam utilizando a metodologia de bioensaios. Estes foram conduzidos durante 14 dias em câmara de crescimento (fitotron) marca Conviron, modelo PVG386, regulado para $25^{\circ} \mathrm{C}, 70-80 \%$ de umidade relativa do ar e fotoperíodo de 12 horas, com intensidade luminosa de 28.400 lúmen $\mathrm{m}^{-2}$, irrigados diariamente para $80 \%$ da capacidade de campo, em copos plásticos (parcela) de $500 \mathrm{~mL}$, sem percolação com $450 \mathrm{~g}$ de substrato. Foram realizados os tratamentos $\left(\mu \mathrm{g} . \mathrm{Kg}^{-1}\right)$ : feijão - 0,0; 1,0; 5,0; 8,0; 10,0; 20,0; soja - 0,0; 0,1; 0,3; 0,5; 1,0. Em função dos resultados, foi avaliada a análise da variância e determinado o modelo de correlação logístico doseresposta, indicando a dose que reduz $50 \%$ a massa fresca epígea (RC50), das espécies avaliadas. A soja se mostrou mais sensível ao herbicida indaziflam, com RC50=1,9 $\mu \mathrm{g} \cdot \mathrm{Kg}^{-1}$, na comparação com o feijão: RC50=3,06 $\mu \mathrm{g} \cdot \mathrm{Kg}^{-1}$. Tendo como base a dose de campo indicada do indaziflam, $100 \mathrm{~g}$ ingrediente ativo por ha, este valor correspondente a 80 $\mu \mathrm{g} . \mathrm{Kg}^{-1},\left(0-10 \mathrm{~cm}\right.$ do perfil do solo, densidade $\left.1,2 \mathrm{~g}^{-\mathrm{cm}^{-3}}\right)$, assim, conclui-se que ambas as plantas avaliadas são sensíveis ao herbicida e podem ser afetadas, em áreas de cultivo com aplicação prévia do herbicida indaziflam, em função da sua longa persistência no solo.

* Bolsista CNPq/PIBIC/IB 
LEVANTAMENTO DA ENTOMOFAUNA ASSOCIADAA RAÇÕES INDUASTRIALIZADAS COMERCIALIZADAS A GRANEL DESTINADAS A ALIMENTAÇÃO DE CÃES. FRANCO,

G. M.*1; POTENZA, M. R. ${ }^{2}$; ${ }^{*}$ Universidade Metodista de São Paulo(UMESP) Rua Alfeu Tavares, 149, CEP 09641-000, São Bernardo do Campo, SP, Brasil; ${ }^{2}$ Instituto Biológico, São Paulo, SP, Brasil. E-mail: gabrielmachadofranco0@gmail.com. Study of insect fauna from industrialized dog food sold in bulk

O ramo de confecção de produtos para animais domésticos demonstra ser uma importante fonte econômica para o Brasil, a qual vem aumentando ao longo dos anos. O presente trabalho teve como objetivo realizar o levantamento da entomofauna associada a rações industrializadas comercializadas a granel, destinadas à alimentação de cães na cidade de São Paulo. O levantamento foi realizado em 25 lojas Pet Shop em diferentes regiões da cidade, a amostragem constou da aquisição de $1 \mathrm{~kg}$ de ração canina industrializada, de duas marcas com maior volume de comercialização, totalizando 50 amostras. O material coletado passou por uma triagem inicial, retirando-se os insetos adultos e larvas presentes. As amostras foram acondicionadas em potes com capacidade de 2-3 litros com tampa devidamente fechada permitindo seu isolamento, com o intuito de permitir a eclosão de ovos e o desenvolvimento larval até a emergência de adultos, a fim de se proceder a uma nova triagem após o período de 50 dias. Das 50 amostras analisadas por uma triagem inicial, 22 (44\%) apresentaram ocorrência de pelo menos uma espécie de inseto-praga, também foi observado em algumas amostras a presença de fios de seda evidenciando a atividade de larvas de traça (Pyralidae). Foi observada uma maior frequência de ocorrência para as espécies Necrobia rufipes e Oryzaephilus surinamensis, ocorrendo em 14\% e 16\% das amostras, respectivamente. As espécies Tribolium castaneum e Oryzaephilus mercator ocorreram ambas em $2 \%$ das amostras. Na segunda triagem foram registrados maiores números de ocorrência para a espécie $N$. rufipes e Oryzaephilus surinamensis, cada uma ocorrendo em $26 \%$ das amostras. T. castaneum apresentou a mesma porcentagem da triagem inicial, e O. mercator ocorreu em $6 \%$ da amostragem total. Foi observada a ocorrência de Lasioderma serricone (2\%).

* Bolsista CNPq/PIBIC/IB 
TENDÊNCIAS GENÉTICAS DE CARACTERÍSTICAS PRODUTIVAS E REPRODUTIVAS EM BOVINOS NELORE. MEDEIROS, G.C..$^{*} ;$ ABREU SILVA, B.C. ${ }^{1 * *}$; ALMEIDA, C.A..$^{1}$; BUSSIMAN, F.O. ${ }^{2^{* * *}}$; EGUTI, F.C. ${ }^{* *} ;$ MATTOS, E.C. ${ }^{1}$; ELER, J.P. ${ }^{1 ;}$ FERRAZ, J.B.S. ${ }^{1}$; Universidade de São Paulo, Faculdade de Zootecnia e Engenharia de Alimentos, Av. Duque de Caxias Norte 225,

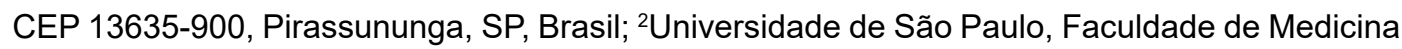
Veterinária e Zootecnia, Av. Duque de Caxias Norte 225, CEP 13635-900, Pirassununga, SP, Brasil. E-mail: gabrielcostamedeiros@usp.br. Genetic trends of productive and reproductive traits in Nellore cattle.

O consumo de proteína animal no mundo apresenta aumento frequente e, dessa forma, é indispensável o estudo do comportamento dos rebanhos brasileiros quanto às características economicamente relevantes. Traçar as tendências genéticas das características produtivas e reprodutivas dos animais permite realizar uma análise do progresso de programas de melhoramento genético e entender qual o rumo tomado pelo rebanho brasileiro, permitindo compreender a situação atual a partir de uma análise histórica. Neste estudo, foram avaliadas as tendências dos valores genéticos aditivos de características produtivas e reprodutivas de 225.744 animais da raça Nelore, nascidos entre 1992 e 2017, pertencentes ao programa de melhoramento genético da raça Nelore da Agropecuária CFM, uma empresa pioneira nesse trabalho e líder de mercado de venda de reprodutores da raça há vários anos. $O$ banco de dados está sob responsabilidade do Núcleo de Apoio à Pesquisa em Melhoramento Animal, Biotecnologia e Transgenia do Departamento de Medicina Veterinária da Faculdade de Zootecnia e Engenharia de alimentos da Universidade de São Paulo. As características produtivas avaliadas neste estudo foram Peso à Desmama (WW), ajustado para 205 dias, o Efeito Materno (MAT), combinação entre o componente genético direto e o componente materno de peso à desmama, o Peso ao Sobreano (YW), ajustado para 550 dias, o Perímetro Escrotal (SC), ligado à qualidade de sêmen e fertilidade de touros jovens, medido ao redor dos 550 dias e o Índice CFM (SI), um índice de seleção desenvolvido para apresentar os animais economicamente superiores. As características reprodutivas avaliadas foram a Probabilidade de Prenhez aos 14 meses (PP14), que é expressa pela porcentagem de prenhez de novilhas quando expostas ao touro em torno dos 14 meses de idade, a Produtividade Anual Média da Vaca (PRODAM), que é expressa em quilogramas de bezerro desmamados anualmente, a Stayability ou Capacidade de Permanência no Rebanho (STAY), medida pela porcentagem de filhas do touro que permanecem produtivas no rebanho após os 6 anos de idade. Os gráficos das tendências genéticas por safra foram obtidos a partir da regressão dos valores genéticos dos animais nas suas respectivas safras de nascimento. As tendências médias por safra encontradas foram: 0,67 Kg/safra; $0,43 \mathrm{Kg} / \mathrm{safra}$; $1,43 \mathrm{Kg} / \mathrm{safra} ; 0,11 \mathrm{~cm} / \mathrm{safra}$ e $0,74 \mathrm{un} / \mathrm{safra}$ para WW, MAT, YW, SC e SI, respectivamente. Para as características reprodutivas o ganho médio anual foi de: $0,61 \% / \mathrm{safra}, 0,24 \mathrm{Kg} / \mathrm{safra}$ e $0,34 \% /$ safra para PP14, PRODAM e STAY, respectivamente. A partir dos resultados obtidos, podese perceber que as tendências dos valores genéticos se apresentaram positivas e favoráveis, indicando que o sistema de seleção aplicado é adequado, representando uma melhoria ao longo do período de seleção no desempenho reprodutivo e produtivo/econômico dos animais.

*Bolsista CNPq(PIBIC)

** Bolsista CAPES(DS)

${ }^{* * *}$ Bolsista FAPESP 
CORRELAÇÕES GENÉTICAS ENTRE VALORES GENÉTICOS ADITIVOS DE CARACTERISTICAS PRODUTIVAS E REPRODUTIVAS EM BOVINOS NELORE. MEDEIROS, G. C. ${ }^{1^{*}}$; ABREU SILVA, B. C..$^{* *}$; ALMEIDA, C. A. ${ }^{1}$; BUSSIMAN, F. O..$^{2^{* *}}$; EGUTI, F. C. ${ }^{1 * *} ;$ MATTOS, E. C.1; ELER, J. P.1; FERRAZ, J.B.S.'; Universidade de São Paulo, Faculdade de Zootecnia e Engenharia de Alimentos, Av. Duque de Caxias Norte 225, CEP 13635-900, Pirassununga, SP, Brasil; 'Universidade de São Paulo, Faculdade de Medicina Veterinária e Zootecnia, Av. Duque de Caxias Norte 225, CEP 13635-900, Pirassununga, SP, Brasil. E-mail: gabrielcostamedeiros@usp.br. Genetic correlations between additive genetic values of productive and reproductive traits in nelore bovine.

Os programas de melhoramento genético animal brasileiros realizam a seleção visando potencializar o desempenho dos animais e, geralmente, mais de uma característica é selecionada. O coeficiente de correlação é a quantificação do grau em que duas variáveis estão relacionadas, assim, pode-se estimar o nível de relacionamento entre duas características utilizadas para a seleção do rebanho. O objetivo desse estudo foi estimar as correlações genéticas entre os valores genéticos aditivos de características produtivas e reprodutivas de bovinos da raça Nelore. O banco de dados utilizado possuía informações de 345.841 animais nascidos entre 1950 e 2017, pertencentes a rebanhos da Agropecuária CFM sob responsabilidade do Núcleo de Apoio à Pesquisa em Melhoramento Animal, Biotecnologia e Transgenia do Departamento de Medicina Veterinária da Faculdade de Zootecnia e Engenharia de Alimentos da Universidade de São Paulo. Para a obtenção das correlações genéticas, foram utilizadas as DEPs das características, a saber, o Perímetro Escrotal (ce), o Peso à Desmama (pdesm), o Efeito Materno Total (mat), o Peso ao Sobreano (psob) e o Índice CFM aos 550 dias (ind550). As características reprodutivas consideradas nesse estudo foram a Produtividade Anual Média da Vaca (prodam), a Stayability ou Capacidade de Permanência no Rebanho (stay) e a Probabilidade de Prenhez aos 14 meses (pp14). Foram estimadas as correlações de Pearson entre as DEPs. As estimativas dos coeficientes de correlação encontrados foram: pdesm e mat $(0,90)$; pdesm e psob $(0,94)$; pdesm e ce $(0,75)$; pdesm e ind550 $(0,89)$; pdesm e pp14 $(0,37)$; pdesm e prodam $(0,25)$; pdesm e stay $(0,24)$; mat e psob $(0,85)$; mat e ce $(0,77)$; mat e ind550 $(0,84)$; mat e pp14(0,37); mat e prodam $(0,26)$; mat e stay $(0,24)$; psob e ce $(0,80)$; psob e ind550 $(0,98)$; psob e pp14 $(0,47)$; psob e prodam $(0,35)$; psob e stay $(0,33)$; ce e ind550 $(0,87)$; ce e pp14(0,57); ce e prodam $(0,34)$; ce e stay $(0,29)$; ind550 e pp14 $(0,57)$; ind550 e prodam $(0,34)$; ind550 e stay $(0,29)$; pp14 e prodam $(0,78)$; pp14 e stay $(0,78)$; prodam e stay $(0,99)$. Todas as estimativas dos coeficientes de correlação foram positivas e favoráveis à seleção. Valores de coeficientes de correlação maiores que 0,20 são suficientes para que haja ganho em resposta correlacionada nos programas de seleção em bovinos de corte. Como todos os coeficientes encontrados foram suficientes, a seleção para cada característica individualmente, auxilia na seleção das outras, sendo dignos de nota os altos valores das produtivas entre si e reprodutivas entre si. Além disso, a relação entre produtivas e reprodutivas também é relevante, provando que a seleção para rebanhos com reprodução mais eficiente, também gera maior produção de carne dos bezerros.

*Bolsista CNPq(PIBIC)

** Bolsista CAPES(DS)

${ }^{* * *}$ Bolsista FAPESP 
ESTIMAÇÃO DE PARÂMETROS GENÉTICOS COM EFEITO MATERNO PARA CARACTERÍSTICAS DE CRESCIMENTO EM OVELHAS DA RAÇA SANTA INÊS. ACERO VADERRAMA, A.S. ${ }^{1 *} ;$ SANTANA, B.F. ${ }^{1 * *} ;$ ABREU SILVA, B.C. ${ }^{1 *} ;$ BUSSIMAN, F.O. ${ }^{2 * *}$; GRIGOLETTO, L. ${ }^{1}$; MATTOS, E.C. ${ }^{1}$; ELER, J.P. ${ }^{1}$; FERRAZ, J.B.S. ${ }^{1}$; ${ }^{1}$ Departamento de Medicina Veterinária, Universidade de São Paulo, Faculdade de Zootecnia e Engenharia de Alimentos, Av. Duque de Caxias Norte 225, CEP 13635-900, Pirassununga, SP, Brasil; ${ }^{2}$ Departamento de Nutrição e Produção Animal, Universidade de São Paulo, Faculdade de Medicina Veterinária e Zootecnia, Av. Duque de Caxias Norte 225, CEP 13635-900, Pirassununga, SP, Brasil; E-mail: alissonacero@usp.br. Estimation of genetic parameters with maternal effects for growth traits in Santa Ines sheep.

$\mathrm{Na}$ seleção de ovinos de corte, os pesos corporais mensurados durante a etapa de nascimento até a desmama dependem dos efeitos genéticos maternos (também dito o valor leiteiro da mãe). Para que haja avanço no processo de seleção de ovinos é de suma importância a estimação dos parâmetros genéticos, bem como o valor dos efeitos genéticos aditivos diretos para estas características de crescimento. No território brasileiro, uma raça tende a ser mais escolhida por sua habilidade materna, a raça Santa Inês. O objetivo do presente trabalho foi estimar parâmetros genéticos para características produtivas em uma população de ovinos da raça Santa Inês, considerando dados fenotípicos de 11.576 animais, nascidos entre 1990 e 2012 oriundos de 45 rebanhos diferentes em vários estados do Brasil (banco de dados sob responsabilidade Grupo de Melhoramento Animal, Biotecnologia e Transgenia (GMAB) -FZEA/USP). O arquivo de pedigree foi composto por 29.080 animais, sendo 2.066 pais e 12.110 mães, porém, nas análises considerou-se até 3 gerações. As características foram: peso ao nascimento (PN); peso à desmama, ajustado para 60 dias (P60) e ganho de peso à desmama (GP60), com 10.303, 6.700 e 5.989 registros, respetivamente. O GP60 foi calculado por meio da soma do PN com o P60, dividida em 60 dias compreendidos no período $(\mathrm{GP} 60=[\mathrm{PN}+\mathrm{P} 60] / 60)$. As estimativas e os parâmetros genéticos foram obtidos pelo método da Máxima Verossimilhança Restrita (REML), utilizando o programa REMLF90, em modelo uni característica com inclusão dos efeitos aleatórios genético aditivo materno e de ambiente permanente materno. As estimativas dos coeficientes de herdabilidade direta $\left(h_{d}\right)$ encontrados, foram moderadas para todas as características, exceto para peso ao nascimento $(P N=0,16)$, estes valores estão de acordo com os encontrados na literatura. Para o GP60 a $h_{d}$ apresentou o valor de 0,32; para o P60 a estimativa encontrada foi 0,37, indicando que estas características se inclusas nos programas de seleção, responderão satisfatoriamente a seleção. As estimativas de herdabilidade materna $\left(h_{m}\right)$ foram maiores para GP60 $(0,12)$, com respeito a PN e P60 $\left(0,07,0,11\right.$, respetivamente) enquanto a herdabilidade total $\left(h_{t}\right)$, em geral foram bem similares ( $P N=0,124 ; P 60=0,128 ; G P 60=0,132$ ). Com isso, podemos afirmar que há uma influência dos efeitos maternos e de ambiente permanente materno sobre as características estudadas, portanto, devem ser consideradas nos estudos de características de crescimento em ovinos. Todas as características sob estudo podem ser utilizadas como critério seletivo em programas de melhoramento.

* Bolsista CAPES(DS)

** Bolsista FAPESP 
COMPARAÇÃO DE MODELOS UNI CARACTERÍSTICA NA ESTIMAÇÃo DE PARÂMETROS GENÉTICOS EM OVELHAS DARAÇA SANTAINÊS. ACERO VADERRAMA, A.S. ${ }^{1 *}$; SANTANA, B.F. ${ }^{1 * *}$; ABREU SILVA, B.C. ${ }^{1 *}$; BUSSIMAN, F.O. ${ }^{2 * *}$; GRIGOLETTO, L. ${ }^{1 \text {; }}$ MATTOS, E.C. ${ }^{1}$; ELER, J.P. ${ }^{1}$; FERRAZ, J.B.S. ${ }^{1}$; ${ }^{1}$ Departamento de Medicina Veterinária, Universidade de São Paulo, Faculdade de Zootecnia e Engenharia de Alimentos, Av. Duque de Caxias Norte 225, CEP 13635-900, Pirassununga, SP, Brasil; '2Departamento de Nutrição e Produção Animal, Universidade de São Paulo, Faculdade de Medicina Veterinária e Zootecnia, Av. Duque de Caxias Norte 225, CEP 13635-900, Pirassununga, SP, Brasil; E-mail: alissonacero@usp.br. Comparison of single-trait model in the estimation of genetic parameters in Santa Inês sheep.

A utilização de metodologias para estimar os parâmetros genéticos e predizer os valores genéticos dos animais de forma mais acurada pode contribuir com o incremento dos ganhos obtidos com a seleção. O objetivo do presente trabalho foi testar dois modelos uni característica na estimação de parâmetros genéticos para características produtivas em ovinos da raça Santa Inês, considerando dados fenotípicos de 11.576 animais, com dados oriundos de 45 rebanhos diferentes em vários estados do Brasil, as características foram: peso ao nascimento (PN); peso à desmama, ajustado para 60 dias (P60); peso aos 180 dias (P180); ganho de peso à desmama (GP60) e ganho de peso pós-desmama (GP180). O GP60 e o GP180 foram calculados por meio da soma do peso inicial com o peso final, para cada período, respectivamente, dividida pelo número de dias compreendidos em cada período (GP60 = $[\mathrm{PN}+\mathrm{P} 60] / 60 ; \mathrm{GP} 180=[\mathrm{P} 60+\mathrm{P} 180] / 120)$. Para PN o grupo de contemporâneo foi composto por ano do nascimento, estação e fazenda, para as demais características, considerou-se somente $o$ ano da pesagem e a fazenda. As estimativas dos componentes de (co)variâncias e os parâmetros genéticos foram obtidos pelo método da Máxima Verossimilhança Restrita (REML), utilizando o programa REMLF90. Os modelos usados foram: $y=X \beta+Z a+e$ (Modelo 1); $y=X \beta+Z a+W_{1} m+W_{2} p+e$ (Modelo 2), em que y é o vetor de observações fenotípica; $\beta$ é o vetor dos efeitos fixos (grupo de contemporâneo); $X$ é a matriz de incidência dos efeitos fixos; a é o vetor do efeito genético aditivo direto; e é o vetor residual; $Z$ é a matriz de incidência dos efeitos genéticos diretos; $p$ é o vetor de efeito de ambiente permanente materno; $W_{1}$ é a matriz de incidência do efeito materno; $m$ é o vetor de observações do efeito aditivo materno; $W_{2}$ é a matriz de incidência do efeito de ambiente permanente materno. O efeito de ambiente permanente materno não foi considerado para P180 e GP180. $\sigma_{\text {ea }}$ foi assumida como zero, assim como, $\sigma_{\mathrm{pm}}, \sigma_{\mathrm{pe}}, \sigma_{\mathrm{pa}}, \sigma_{\mathrm{em}}$. Para testar a diferença entre os modelos usados, foram feitas comparações pelo critério de informação de Akaike (AIC) e pelo logaritmo de verossimilhança (-2Log), obtidos pelo mesmo programa. Os coeficientes de herdabilidade do Modelo 1, foram de média a alta magnitude em todas as características, já no Modelo 2 as estimativas dos coeficientes encontrados foram moderadas, corroborando com a literatura. Os resultados evidenciaram que a não inclusão do efeito materno e de ambiente permanente materno no modelo de estimação, pode inflacionar os componentes de variância, resultando em uma superestimação dos mesmos. O Modelo 2, foi o mais adequado pois apresentou o AIC menor para todas as características estudadas, mostrando que existe influência significativa destes efeitos nas estimações dos parâmetros genéticos.

* Bolsista CAPES(DS)

** Bolsista FAPESP 
APLICABILIDADE DOS MÉTODOS MCMASTER E FAMACHAC EM OVINOS CRIADOS EM PEQUENA PROPRIEDADE RURAL*. PASSOS, V.T.**1; RIGAMONTE, B.L. ${ }^{* * 1}$; ROMERA, D.M. ${ }^{2}$; SILVA, R.A. ${ }^{3}$; SILVA, G.S. ${ }^{1}{ }^{1 *}$ Agência Paulista de Tecnologia dos Agronegócios (APTA)/ Instituto Biológico, Laboratório de Parasitologia Animal de Votuporanga, Rodovia Péricles Belini, s/n, Caixa Postal 61, CEP 15505-970, Votuporanga, SP, Brasil. ${ }^{2}$ APTA/IAC, Centro de Seringueira e Sistemas Agroflorestais. ${ }^{3} E D R$ Votuporanga/ Coordenadoria de Desenvolvimento Rural Sustentável. E-mail: vittor.passos@gmail.com. Applicability of McMaster and FAMACHA® methods in sheeps in small rural property.

A ovinocultura pode constituir-se em atividade alternativa para o desenvolvimento rural sustentável, seja pela menor necessidade de capital inicial, pela possibilidade de acumulação de renda em pequena escala ou por sua importância socioeconômica. Por outro lado, as endoparasitoses podem determinar perdas econômicas significativas no plantel ovino, uma vez que os helmintos atuam de forma clínica ou subclínica, causando grandes prejuízos. A presente pesquisa teve como objetivo verificar a aplicabilidade dos métodos McMaster e FAMACHAC como ferramentas a serem utilizadas em estratégias de controle das helmintoses em ovinos. Para tanto, um rebanho ovino caracterizado como atividade familiar foi selecionado com base em visitas e entrevistas conduzidas em diferentes propriedades. Após seleção, periodicamente foram realizadas avaliações parasitológicas, por meio de exames coproparasitológicos e clínicos (OPG, coprocultura, método FAMACHAC e hematócrito). O emprego do método Famacha@ para tomada de decisão de tratamento anti-helmíntico propiciou diminuição no número de tratamento dos animais, considerando que o produtor adotava tratamentos mensais. Sugere-se a utilização dos métodos Famacha@ para avaliação dos animais, associada a exames coprológicos (OPG e coprocultura), para garantir melhor eficácia no tratamento anti-helmíntico de ovinos.

**Bolsista CNPq/PIBIC/IB 
APLICABILIDADE DOS MÉTODOS MCMASTER E FAMACHAC EM OVINOS CRIADOS EM PEQUENA PROPRIEDADE RURAL*. PASSOS, V.T.**1; RIGAMONTE, B.L. ${ }^{* *}$; ROMERA, D.M. ${ }^{2}$; SILVA, R.A. ${ }^{3}$; SILVA, G.S. ${ }^{1{ }^{1 *} A g e ̂ n c i a ~ P a u l i s t a ~ d e ~ T e c n o l o g i a ~}$ dos Agronegócios (APTA)/ Instituto Biológico, Laboratório de Parasitologia Animal de Votuporanga, Rodovia Péricles Belini, s/n, Caixa Postal 61, CEP 15505-970, Votuporanga, SP, Brasil. ${ }^{2}$ APTA/IAC, Centro de Seringueira e Sistemas Agroflorestais. ${ }^{3}$ EDR Votuporanga/ Coordenadoria de Desenvolvimento Rural Sustentável. E-mail: vittor.passos@gmail.com. Applicability of McMaster and FAMACHA® methods in sheeps in small rural property.

A ovinocultura pode constituir-se em atividade alternativa para o desenvolvimento rural sustentável, seja pela menor necessidade de capital inicial, pela possibilidade de acumulação de renda em pequena escala ou por sua importância socioeconômica. Por outro lado, as endoparasitoses podem determinar perdas econômicas significativas no plantel ovino, uma vez que os helmintos atuam de forma clínica ou subclínica, causando grandes prejuízos. A presente pesquisa teve como objetivo verificar a aplicabilidade dos métodos McMaster e FAMACHAC como ferramentas a serem utilizadas em estratégias de controle das helmintoses em ovinos. Para tanto, um rebanho ovino caracterizado como atividade familiar foi selecionado com base em visitas e entrevistas conduzidas em diferentes propriedades. Após seleção, periodicamente foram realizadas avaliações parasitológicas, por meio de exames coproparasitológicos e clínicos (OPG, coprocultura, método FAMACHAC e hematócrito). O emprego do método Famacha@ para tomada de decisão de tratamento anti-helmíntico propiciou diminuição no número de tratamento dos animais, considerando que o produtor adotava tratamentos mensais. Sugere-se a utilização dos métodos Famacha@ para avaliação dos animais, associada a exames coprológicos (OPG e coprocultura), para garantir melhor eficácia no tratamento anti-helmíntico de ovinos.

**Bolsista CNPq/PIBIC/IB 
HERPESVIRUS BOVINO TIPOS 1 e 5 E HERPESVIRUS BUBALINO TIPO 1: ESTUDO RETROSPECTIVO EM REBANHOS BUBALINOS DO ESTADO DE SÃO PAULO. DOMINGOS, A ${ }^{1 *}$; ZANCO, G.J. ${ }^{1 ;}$ VIZIGALI, A.C.C. ${ }^{1}$; MARTINEZ, R.R. ${ }^{1}$; MONTEIRO, B. ${ }^{4}$; STURARO, M.J.R. ${ }^{1}$; STEFANO, E. ${ }^{1}$; ROMALDINI, A.H.C.N. ${ }^{1}$; CHIEBAO, D.P. ${ }^{1}$; CARUSO, C. ${ }^{3}$; VECCHIO, D.2; PITUCO, E.M.5; OKUDA, L.H¹. Instituto Biológico, Centro de Pesquisa de Sanidade Animal, Av. Cons. Rodrigues Alves, 1252, CEP 04014-900, São Paulo, SP, Brasil. 'Laboratório de Viroses de Bovídeos Instituto Biológico, São Paulo, SP. E-mail: amandadomingos26@gmail.com. Bovine herpesvirus types 1 and 5 and bubaline herpesvirus type 1: retrospective study in buffalo herds of the state of São Paulo.

Os herpesvírus bovinos (BoHV) e herpesvirus bubalinos (BuHV) são os agentes etiológicos que geram grande prejuízo econômico, gerando falhas reprodutivas e perdas significativa na criação. Estudos sorológicos têm sugerido que búfalos podem ser suscetíveis ao BoHV1 e outros alphaherpesvirus geneticamente relacionados. Desta forma, o objetivo geral da presente pesquisa foi avaliar a presença das herpesviroses em rebanhos bubalinos criados no estado de São Paulo. Dentre os objetivos específicos destacamos: 1) avaliar a presença de anticorpos anti-BuHV-1 utilizando kit comercial (IN3 diagnostic $®)$ ), que é capaz de distinguir anticorpos anti-BuHV-1 e BoHV-1 no soro do animal; 2) detectar anticorpos anti-BoHV-1 e BoHV-5 pela virusneutralização e 3 ) avaliar reação cruzada entre os testes diagnósticos. No total foram analisadas 858 amostras de soro bubalino, sendo 692 pertencentes do Vale do Ribeira e 166 da região de Sorocaba. Estas amostras foram coletadas dos mesmos animais em diferentes períodos. Das 858 amostras de soro bubalino analisadas na virusneutralização, a média de frequência de anticorpos para $\alpha$ BoHV foi de $84 \%$ (562 soros do Vale do Ribeira e 161 de Sorocaba), com título de anticorpos, na escala logarítmica de $\log _{10} 0,3$ a 3 (escala aritmética 2 a 2048). No teste de ELISA comercial foram detectados 13\% (107) de animais reagentes para BuHV1, 1\% (4/858) foi indeterminado, ou seja, apresentou soro positividade tanto para BuHV-1 como para o BoHV-1. Considerando que essas amostras foram colhidas de animais em diferentes dias e momentos, explica a variação do título de anticorpos de cada animal. Os búfalos da região de Sorocaba eram bezerros, cujos soros foram colhidos antes de mamarem o colostro e foram monitorados para avaliação da transferência passiva de anticorpos para BoHV. No caso da região do Vale do Ribeira foram avaliadas búfalas em idade reprodutiva. Diante dos resultados obtidos nessa pesquisa demonstrou-se a reatividade cruzada entre os testes de virusneutralização para BoHV-1 e BoHV-5, embora na região do vale do Ribeira, a titulação seja maior para BoHV-5 e na região de Sorocaba, a titulação foi maior para BoHV-1. Os resultados indicam que existe reatividade cruzada entre os herpesvirus bovino e bubalino, entretanto no teste de ELISA comercial, foi observado soropositividade para BoHV-1 somente em $1 \%$ dos animais contra $13 \%$ para BuHV-1. Desta forma, podemos sugerir que deve ocorrer maior reatividade cruzada entre BoHV-5 e BuHV1 e, portanto, estudos devem ser aprofundados para avaliar essa hipótese.

\footnotetext{
* Bolsista CNPq/PIBIC/IB

${ }^{1}$ Instituto Biológico, Av. Conselheiro Rodrigues Alves, 1252 - Vila Mariana, São Paulo - SP, 04014-900

${ }^{2}$ Istituto Zooprofilattico Sperimentale Del Mezzogiorno - Centro di Referenza Nazionale Sull'igiene e Tecnologie dell'Allevamento e delle Produzioni Bufaline

${ }^{3}$ Istituto Zooprofilattico Sperimentale del Piemonte, Liguria e Valle d'Aosta

${ }^{4}$ Universidade Federal Rural da Amazônia - Campus Aragomina

${ }^{5}$ PANAFTOSA
} 
APLICAÇÃO DA TÉCNICA DE IMUNOCITOQUÍMICA PARA IDENTIFICAÇÃO DE ROTAVÍRUS EM AMOSTRAS DE FEZES DE SUÍNOS PROVENIENTES DE GRANJAS DO ESTADO DE SÃO PAULO, SP. LUZ, L.S.M.*; PEDROSO, I.M.; BERSANO, J.G.; MARTINS, A.M.C.R.P.F.; OGATA, R.A.; CATROXO, M.H.B. Instituto Biológico, Centro de Pesquisa e Desenvolvimento de Sanidade Animal, Av. Cons. Rodrigues Alves, 1252, CEP 04014-900, São Paulo, SP, Brasil. E-mail: la.smluz98@outlook.com. Application of the immunocytochemistry technique for rotavirus identification in swine feces samples from farms in the State of São Paulo, SP, Brazil.

O Rotavírus suíno pertence à família Reoviridae e ao gênero Rotavirus, sendo o grupo A o mais frequentemente detectado no Brasil, em leitões de 1 a 8 semanas de idade, com diarreia. A doença é caracterizada por grave diarreia, altamente contagiosa, aquosa, de coloração esbranquiçada a amarelada; vômitos; náusea; prostração e desidratação, que podem perdurar de 2 a 5 dias. A transmissão ocorre via fecal-oral disseminando-se rapidamente entre os animais de maternidade. A rotavirose suína tem um importante impacto na indústria suinícola, causando prejuízos econômicos às granjas, devido às perdas no ganho de peso dos animais recuperados, custos com tratamentos e medicamentos, alta taxa de morbidade e de mortalidade, além da desuniformização dos lotes ao desmame. $\mathrm{O}$ objetivo deste trabalho visou implementar a técnica de imunocitoquímica (imunomarcação com ouro coloidal), para detectar o rotavírus em amostras de fezes diarreicas de suínos provenientes de granjas do estado de São Paulo. No período de outubro de 2016 a junho de 2019, foi colhido um total de 53 amostras de suínos, com idade variando entre 1 a 20 dias, provenientes de granjas do estado de São Paulo, SP. As amostras foram processadas pela técnica de imunocitoquímica (imunomarcação com ouro coloidal). Nessa técnica, as telas metálicas são colocadas em contato com a suspensão viral por 15 minutos e, após, removido o excesso com papel filtro, são incubadas com gotas do anticorpo específico para o rotavírus tipo $\mathrm{A}$, diluído a 1:80 por 30 minutos. Após, as telas são lavadas com gotas de PBS e, posteriormente, incubadas em gotas de proteína A conjugada com ouro de $10 \mathrm{~nm}$, durante 30 minutos, contrastadas com gotas de molibdato de amônio a $2 \%$ e examinadas ao microscópio eletrônico de transmissão Philips EM 208. Dessas 53 amostras, $24(45,30 \%)$ apresentaram-se positivas para rotavírus. A técnica de imunocitoquímica aplicada evidenciou a reação antígeno-anticorpo, que foi fortemente realçada pelas partículas densas de ouro coloidal sobre os rotavírus. A técnica mostrou-se eficiente para o diagnóstico rápido do rotavírus, favorecendo a implementação de medidas profiláticas e de controle da doença nas granjas acometidas pelos surtos.

${ }^{*}$ Bolsista CNPq/PIBIC/IB 
ACHADOS ANATOMOPATOLÓGICOS EM EQUINOS COM MORMO. SANTOS, C.B. ${ }^{1 *}$; FONSECA, A.A. ${ }^{1 *}$; NASSAR, A.F.C. ${ }^{1}$; ROMALDINI, A.H.C.N. ${ }^{1}$; CHIEBAO, D.P. ${ }^{1}$; MAGRINHO, F.C.B. ${ }^{2}$; DIZ, S.M.L. ${ }^{2}$; LEZIER, D.H. ${ }^{2}$; GONÇALVES, R.C. ${ }^{3}$; ARAÚJO, M.C.S. ${ }^{4}$; SIMÕES, H.M.Q. ${ }^{4}$; ALVIM, A.P.C.S. ${ }^{5}$; POMPEI, J.C.A. ${ }^{5}$ MARQUES, G.H.F. ${ }^{6}$; PITUCO, E.M. ${ }^{7}$; DEL FAVA, C. ${ }^{1}$ 1. Instituto Biológico, Av. Cons. Rodrigues Alves 1252, CEP 04014-002, São Paulo, SP, Brasil; 2. Coordenadoria de Defesa Agropecuária do Estado de São Paulo, Campinas, SP, Brasil. 3. Escritório de Defesa Agropecuária de São Paulo, SP, Brasil. 4. Estação Quarentenária de Cananéia, SP, Brasil. 5. Centro Panamericano de Febre Aftosa/ OPS/OMS, Duque de Caxias, RJ, Brasil. 6. Departamento de Saúde Animal, Ministério da Agricultura, Brasília, DF, Brasil. 7. Laboratório de Referência, Centro Panamericano de Febre Aftosa/OPS/OMS, Pedro Leopoldo, MG, Brasil. E-mail: caroline-santos@hotmail.com. Anatomopathological findings in equine with glanders.

O Mormo, zoonose causada pela bactéria Burkholderia mallei, afeta equídeos e manifesta-se de forma aguda ou crônica, causando granulomas pulmonares no trato respiratório, linfangite e linfadenite caseosa. Pelo fato desta doença causar grave infecção respiratória e ser de difícil tratamento em seres humanos e animais, sua notificação é obrigatória aos órgãos de Defesa Sanitária Animal e a eutanásia dos equinos sororeagentes é compulsória, devendo as provas sorodiagnósticas ser realizadas em laboratório credenciado pelo Ministério da Agricultura, Pecuária e Abastecimento (MAPA). O presente trabalho foi aprovado pelo Comitê de Bioética em Experimentação Animal do Instituto Biológico (CETEA registro 142/2015). Foram selecionados 22 cavalos positivos e oito negativos ao Mormo pela prova de triagem Fixação de Complemento (FC), os positivos confirmados pelo Western Blotting (WB) oriundos de focos de Mormo. Os animais foram necropsiados, alguns após óbito natural e outros eutanasiados conforme a Resolução CFMV1000/2012, para colheita de amostras de órgãos para histopatológico. Alíquotas de tecidos foram fixadas em formol $10 \%$ tamponado e emblocadas em parafina para o exame histopatológico por coloração hematoxilina/eosina. As principais alterações macroscópicas observadas nos 22 equinos positivos confirmados pelo WB foram: emaciação (4), linfangite de membros (3), edema de membros (2), úlcera em boleto (3), sinusite (4), catarro nasal purulento (5), secreção nasal necrótica (2), lesão hemorrágica pulmonar (4), lesões miliares em pulmão (7), linfonodo mediastínico aumentado (5), cicatrização estrelada de cápsula esplênica (8), fibrose de borda hepática (6), lesões em cápsula hepática (5) e Aderência de cápsula renal (6). As principais alterações macroscópicas observadas nos oito equinos negativos na FC foram: Aderência de cápsula renal (2), esplenomegalia (1), fibrose de borda hepática (1), e lesões em parênquima hepático (1). A histopatologia nos equinos positivos no WB revelou em 12 animais broncopneumonia purulenta, 15 animais com espessamento de pleura pulmonar, 15 animais com espessamento de septo alveolar, e oito animais apresentaram granulomas pulmonares com associação de células gigantes multinucleadas (células de Langhans); nos linfonodos, 11 apresentaram reação linfoide e, apenas um tinha abscesso; hemossiderose esplênica foi presente em 12 casos. Nos negativos a histopatologia revelou em seis animais espessamento de pleura pulmonar; nos linfonodos, sete apresentaram intensa reação linfoide. Vários animais positivos ao Mormo no WB apresentaram à macroscopia e microscopia lesões típicas descritas na literatura científica: linfadenite, sinusite, granulomas pulmonares e linfangite, sendo que o grau de acometimento depende do estágio agudo ou crônico da doença e da imunidade individual. O diagnóstico do Mormo foi realizado por sorodiagnóstico de triagem (FC) e confirmatório (WB), sendo que os achados clínicos e anatomopatológicos são complementares e ilustram as lesões macroscópicas e microscópicas da doença.

* Bolsista CNPq/PIBIC/IB 
AVALIAÇÃO DA DISTRIBUIÇÃO DE ANTICORPOS ANTI-Toxoplasma gondii EM BOVINOS (Bos taurus) NO BRASIL PELA TÉCNICA DE IMUNOFLUORESCÊNCIA INDIRETA (IFI). HILST, V. C. ${ }^{* 1}$; ROMALDINI, A.H.C.N. ${ }^{1}$; OKUDA, L.H. ${ }^{1}$; SEVÁ, A.P. ${ }^{2}$; DOMINGOS, A.*1; CHIEBAO, D. ${ }^{1}$ Instituto Biológico, Laboratório de Viroses de Bovídeos, Av. Conselheiro Rodrigues Alves 1252, CEP 04014-900, Vila Mariana, São Paulo, SP, Brasil. '2Universidade Estadual de Santa Cruz, Rod. Jorge Amado, Km 16, CEP 45662900, Salobrinho, Ilhéus, BA, Brasil. E-mail: victor.hilst@uol.com.br. Evaluation of antiToxoplasma gondii antibodies distribuition in cattle (Bos taurus) in Brazil by the indirect immunofluorescence technique (IFAT).

$\mathrm{Na}$ bovinocultura, a capacidade reprodutiva é um dos tópicos mais importantes para valorização de um rebanho, sendo mensurada por taxas de concepção, índices de prenhez e parição e intervalo entre partos. As causas para perda desta capacidade são multifatoriais, desde desordens nutricionais, problemas de manejo, doenças infecciosas e parasitárias. Dentre as doenças parasitárias em animais de produção, a toxoplasmose, causada pelo protozoário Toxoplasma gondii, protozoário intracelular obrigatório capaz de infectar animais homeotérmicos, incluindo o homem, é umas das mais disseminadas mundialmente. Seu ciclo de vida é heteroxênico facultativo, sendo os felídeos os hospedeiros definitivos e mamíferos ou aves os hospedeiros intermediários. O consumo elevado de carnes, principalmente de suínos e ovinos, minimamente processadas aumenta o risco da infecção devido a possível presença de cistos na musculatura. Este estudo teve como objetivo analisar a ocorrência de anticorpos anti- $T$. gondii em bovinos pela reação de imunofluorescência indireta (RIFI), associa-la com a ocorrência de Neosporose, outra enfermidade causadora de abortamento, e a confecção de lâminas próprias para a análise de RIFI. As amostras utilizadas foram soro sanguíneo e líquido torácico de bovinos de diversos municípios do Brasil que foram encaminhados ao Laboratório de Viroses de Bovídeos, do Centro de Pesquisa e Desenvolvimento de Sanidade Animal do Instituto Biológico visando a pesquisa de anticorpos anti-Neospora caninum através do teste ELISA. Para confecção das lâminas foi realizado o cultivo celular de células da linhagem VEROCCL 81 (rim de macaco verde africano), proveniente do Americam Type Cell Colection (ATCC) na passagem 120 para a manutenção e produção dos taquizoítos de T. gondii. Foram analisadas 299 amostras de soro sanguíneo de bovinos, a ocorrência de anticorpos anti-T. gondii foi de $41 \%(123 / 299$, IC 95\%, 37\%-49\%) e de anticorpos anti-N. caninum de $31 \%(94 / 299$, IC 95\% 26\%-37\%) com 47 (15,7\%) apresentando anticorpos para ambos. Através do teste do $X^{2}$, observou-se significância $(p=0,001755)$ entre o resultado das duas análises. Na rotina diagnóstica a análise de $N$. caninum é a mais solicitada. No entanto, houve uma maior ocorrência de amostras reagentes à Toxoplasma gondii, reforçando a importância de realizar o diagnóstico diferencial para outras enfermidades causadoras de abortamento.

${ }^{*}$ Bolsista PIBIC/IB/CNPq 
CONTROLE DE CARRAPATOS COM OS FUNGOS Metharhizium anisopliae E Beauveria bassiana EM EQUINOS NO HARAS VILA COLONIAL - ANALÂNDIA/SP - RESULTADOS PRELIMINARES. FURLAN, B.P.1*; DUARTE, F.C.'; FIORINI, L.C.'; ARAUJO, S.B.S.2; ALMEIDA, I.B.; SAMPAIO, P.H.S.; MENDES, M.C. ${ }^{3}{ }^{2}$ UNIFEOB - Centro Universitário Fundação de Ensino Octávio Bastos, Avenida Dr. Octávio Bastos, 2439, Jd Nova São João, CEP 13.874-651, São João da Boa Vista, SP, Brasil. nstituto Biológico, Programa de PósGraduação em Parasitologia Animal, São Paulo, SP, Brasil. ${ }^{3}$ nnstituto Biológico, Laboratório de Parasitologia Animal, São Paulo, SP, Brasil. E-mail: bruna.furlan2008@yahoo.com.br. Treat control with fungi Metharhizium anisopliae and Beauveria bassiana in haras Village Colonial - Analândia/SP - Preliminary results.

As espécies Amblyomma sculptum e Dermacentor nitens destacam-se como espécies de importância para os equinos, por serem responsáveis por diversos danos provocados, como estresse, espoliação sanguínea, predisposição a miíases e infecções bacterianas, além de serem responsáveis pela transmissão de agentes infecciosos. A presente pesquisa tem como objetivo avaliar a eficácia da utilização de fungos entomopatogênicos aplicados na pastagem no controle dos ectoparasitas $A$. sculptum e $D$. nitens. $O$ teste foi realizado na propriedade Haras Vila Colonial, localizada no município de Analândia, SP. Quarenta piquetes foram analisados quanto à infestação de carrapatos, sendo que foi verificada maior infestação da espécie $D$. nitens. Foram selecionados vinte para receber o tratamento: 7 piquetes-controles, 6 piquetes receberam aplicação do fungo $M$. anisopliae e 7 piquetes receberam aplicação do fungo $B$. bassiana. As aplicações foram feitas com pulverizador de dois bicos da marca Jacto, acoplado ao trator Valtra BM110. O critério de avaliação de infestação de carrapatos nas orelhas dos equinos foi por fotos realizadas nas seguintes classificações: Classificação I (sem infestação); Classificação II (1 a 5 carrapatos); Classificação III (6 a 15 carrapatos) e Classificação IV (acima de 15 carrapatos). Foram realizadas três leituras de infestação dos equinos, nos dias 25/5, 11/6 e 26/6, nos grupos controle e tratados. Os animais que apresentaram infestação acima de III foram tratados com Tanidil@ (Fármaco ectoparasiticida de uso tópico nas orelhas, com princípio ativo de Coumafós e Propoxur).

*Bolsista CNPq/PIBIC/IB 
EFEITODAACLIMATAÇÃOADIFERENTESTEMPERATURASSOBREASENSIBILIDADE TÉRMICA DA RESPOSTA IMUNE DA RÃ-TOURO (Lithobates catesbeianus). LIMA, A.S. ${ }^{*}$; FERREIRA, L. de F. ${ }^{1,2 * *}$; TITON, S.C.M. ${ }^{1}$; GOMES, F.R. ${ }^{1}{ }^{1}$ Universidade de São Paulo (IB-USP), Instituto de Biociências, Departamento de Fisiologia, Rua do Matão, trav. 14, n 321, CEP 05508-090, São Paulo, SP, Brasil. 'Faculdade de Filosofia, Ciências e Letras - FAFIL/Centro Universitário Fundação Santo André (FSA), Santo André, SP, Brasil. E-mail: alanslima0@gmail.com. Effect of acclimatization at different temperatures on the thermal sensitivity of the bullfrog's (Lithobates catesbeianus) immune response.

Os anfíbios estão vivenciando um rápido declínio populacional ao redor do mundo. Esse padrão está associado a diversos fatores, sendo os mais recorrentes atribuídos às alterações dos regimes térmicos e à ocorrência de doenças emergentes. Alterações de temperatura influenciam tanto a fisiologia do patógeno, quanto a capacidade do hospedeiro em desempenhar uma resposta imune eficaz contra agentes infecciosos. Entretanto, pouco se conhece sobre a sensibilidade térmica da resposta imune dos anfíbios. Diante disso, o presente trabalho investigou o efeito da aclimatação a diferentes temperaturas $\left(28^{\circ} \mathrm{C}\right.$ e $34^{\circ} \mathrm{C}$ ) sobre a sensibilidade térmica da resposta imune (capacidade bactericida plasmática - CBP - e atividade de fagocitose de leucócitos sanguíneos) de rãs-touro (Lithobates catesbeianus). Os animais foram inicialmente mantidos a $28{ }^{\circ} \mathrm{C}$ (7 dias). Após 37 dias nessas condições, os animais foram divididos em dois grupos, que permaneceram a $28^{\circ} \mathrm{C}$ e $34{ }^{\circ} \mathrm{C}$ por 45 dias. Amostras de sangue foram coletadas nos dias 7, 57 e 77 do experimento. Os ensaios de fagocitose e CBP foram realizados em 8 temperaturas de incubação diferentes, compreendendo um gradiente de $5{ }^{\circ} \mathrm{C}$ a $40{ }^{\circ} \mathrm{C}$, para determinar a curva de sensibilidade térmica desses dois componentes da resposta imune. As curvas de sensibilidade térmica demonstram efeito da temperatura de incubação sobre a CBP (F5,50 $=143,976, \mathrm{P}<0,001)$, com os maiores valores desse índice entre $5-20{ }^{\circ} \mathrm{C}$, e gradual redução com o aumento da temperatura $\left(25-40^{\circ} \mathrm{C}\right)$. Ademais, a CBP caiu ao longo do tempo de experimento em rãs submetidas às duas temperaturas experimentais ( $F 12,129$ $=14,312, \mathrm{P}<0,001)$, de forma associada à perda de sensibilidade térmica. As diferentes temperaturas de manutenção dos animais $\left(28^{\circ} \mathrm{C}\right.$ ou $\left.35^{\circ} \mathrm{C}\right)$ não tiveram efeito sobre as curvas de sensibilidade térmica da $\operatorname{CBP}(F 5,50=1,501, P=0,206)$. Entretanto, os animais mantidos a $34{ }^{\circ} \mathrm{C}$ demonstraram uma queda mais acentuada da $\mathrm{CBP}$, principalmente nas temperaturas em que esta foi máxima (entre $5-20{ }^{\circ} \mathrm{C}$ ), quando comparados com os animais mantidos a $28{ }^{\circ} \mathrm{C}$. Isso pode estar associado à perda de massa corpórea, que ocorreu em ambos os grupos ( $F 2,20=8,837, P=0,002)$, porém de forma mais acentuada nos animais expostos a $34{ }^{\circ} \mathrm{C}$. A atividade fagocítica medida no dia 7 não apresentou efeito da temperatura $(F 2,23=2,373, P=0,107)$. Os demais dados de fagocitose ainda estão sendo adquiridos e analisados. Os dados indicam um caráter euritérmico da resposta imune das rãs e ausência de aclimatação dessa resposta.

*Bolsista FAPESP/IB-USP

${ }^{* *}$ Bolsista PIBIC/IB-USP 
QUALIDADE DA ÁGUA DE IRRIGAÇÃO DE HORTALIÇAS FOLHOSAS. SOUZA, C.S.M. ${ }^{* 1,2}$; PETROCELLI, B.M. ${ }^{* * 3}$; SOUZA, G.S. ${ }^{1}$; FERREIRA, R.C.B. ${ }^{1}$; VIEIRA, E. ${ }^{11}$ Instituto Biológico, Laboratório de Ecologia de Agroquímicos, Av. Conselheiro Rodrigues Alves, 1252, CEP 04014-900, São Paulo, SP, Brasil. 'Universidade Santo Amaro, São Paulo, SP. ${ }^{3}$ Instituto Biológico, Pós Graduação em Sanidade, Segurança Alimentar e Ambiental no Agronegócio, São Paulo, SP. E-mail: cleliamattos-souza@hotmail.com. Irrigation water quality of leafy vegetables.

No pós-guerra, a base do padrão agrícola tornou-se o uso de agroquímicos, mecanização, cultivares de alto potencial de rendimento e técnicas de irrigação, visando ao aumento da produtividade. Hoje, o Brasil é um grande consumidor de agrotóxicos e fertilizantes e esses produtos quando aplicados de forma incorreta podem contaminar o ambiente. Um dos principais problemas da qualidade da água em área rural é a contaminação por nutrientes, que em larga escala pode causar a eutrofização do meio aquático. Outro problema relacionado à qualidade da água é a contaminação microbiológica, que pode levar à contaminação de águas superficiais e subterrâneas por micro-organismos nocivos à saúde. Dessa forma, o monitoramento da qualidade da água é de extrema importância para a saúde humana e ambiental. O objetivo deste trabalho foi avaliar a contaminação por agrotóxicos, fertilizantes e microbiológica, em água de irrigação. A coleta das amostras de água destinadas à irrigação de hortaliças foi realizada em sete pontos, nas cidades de Brotas e Ibiúna, SP, que incluem sistemas de cultivo orgânico, convencional e hidropônico. Dos pontos $(\mathrm{P})$ amostrados $\mathrm{P} 1$ é água de uma nascente, P2 é água de poço raso, P6 é água de um lago e os demais provêm de rios. Os agrotóxicos analisados não foram encontrados na água coletada. Nos pontos P1 e P7 o fosfato estava acima do limite permitido para águas superficiais e no P2 o nitrato estava acima do limite permitido para águas subterrâneas. Como a legislação diz que as águas de irrigação de hortaliças folhosas devem ser enquadradas na Classe 1 e esses parâmetros estão acima do permitido, a água em P1, P2 e P7 não possuí padrões adequados quanto aos nutrientes. Em todos os pontos foi confirmada a presença de coliformes termotolerantes, $80 \%$ estava acima do limite máximo permitido e em $90 \%$ dos pontos foi encontrada a presença de Escherichia coli, Esta última não tem legislação vigente sobre a quantidade máxima permitida em água de irrigação. Somente os pontos de amostragem P4 e P6, ambos em Brotas, apresentaram água em conformidade com os parâmetros analisados.

\footnotetext{
${ }^{*}$ Bolsista CNPq/PIBIC/IB

**Bolsista Capes Pós-Graduação em Sanidade, Segurança Alimentar e Ambiental no Agronegócio/IB
} 
VALIDAÇÃO DE METOdOLOGIA ANALÍTICA PARA ANÁLISE DE RESÍDUOS DE AGROTÓXICOS EM ÁGUA. SOUZA, C.S.M. ${ }^{* 1,2}$; PETROCELLI, B.M. ${ }^{* * 3}$; FERREIRA, R.C.B. ${ }^{1}$; VIEIRA, E. ${ }^{1}{ }^{1}$ Instituto Biológico, Laboratório de Ecologia de Agroquímicos, Av. Conselheiro Rodrigues Alves, 1252, CEP 04014-900 São Paulo, SP, Brasil. 'Universidade Santo Amaro, São Paulo, SP. IInstituto Biológico, Pós-Graduação em Sanidade, Segurança Alimentar e Ambiental no Agronegócio. E-mail: cleliamattos-souza@hotmail.com. Validation of analytical methodology for pesticide residue in water.

Agrotóxicos são amplamente utilizados para controlar pragas, doenças e proteger os cultivos agrícolas. O Brasil apresenta uma elevada taxa de crescimento no setor agropecuário, Dessa forma, o uso de agrotóxicos vem crescendo exponencialmente, tornando o país o maior mercado de agrotóxicos no mundo. Os agrotóxicos são aplicados sobre os cultivares ou no solo e podem causar a contaminação do solo, águas superficiais e subterrâneas. O objetivo deste trabalho foi validar metodologia analítica para análise de resíduos de agrotóxicos em água. A linearidade, o limite de detecção, o limite de quantificação e a exatidão foram os parâmetros de desempenho analisados. Os agrotóxicos imidacloprido, tiametoxam, fipronil, atrazina, metalaxil e difenoconazole, e os metabólitos da atrazina DIA e DEA foram avaliados. O método de extração utilizado foi o líquido-líquido, com extração de $1 \mathrm{~L}$ de água com $30 \mathrm{~mL}$ de diclorometano por 3 vezes, o extrato foi concentrado em evaporador rotatório e ressuspendido em acetonitrila. As amostras foram injetadas no cromatógrafo líquido de alta eficiência com o detector UV e coluna Agilent Zorbax Eclipse C18 $5 \mu \mathrm{m}(150 \times 4,6 \mathrm{~mm})$. O sistema operou com fluxo de 0,7 mL. min-1 com a fase móvel de 25:75 acetonitrila água até 22 minutos e 50:50 até 50 minutos. O comprimento de onda variou de 223 a $254 \mathrm{~nm}$. A seletividade e a linearidade foram avaliadas baseadas na avaliação de seis concentrações dos agrotóxicos. A linearidade teve um coeficiente de correlação superior a 0,99 para todos os princípios ativos em uma faixa de trabalho variando de 0,40 a 10 mg.L-1. A exatidão, a precisão, o limite de quantificação e o limite de detecção foram determinados através da recuperação dos analitos na água. Os princípios ativos DIA e DEA apresentaram porcentagens de recuperação inferiores a $55 \%$ e não foram validados, uma vez que a recuperação não foi aceitável. Os princípios ativos imidacloprido, tiametoxam, fipronil, atrazina, metalaxil, fipronil e difenoconazole apresentaram porcentagens de recuperação entre 70 e 130\%, demonstrando a adequação da metodologia para a finalidade pretendida.

${ }^{*}$ Bolsista CNPq/PIBIC/IB

**Bolsista Capes Pós-Graduação em Sanidade, Segurança Alimentar e Ambiental no Agronegócio/IB 
CARACTERIZAÇÃO DEMOGRÁFICA DOS “ARQUIVOS DO INSTITUTO BIOLÓGICO” (AIB) NO FACEBOOK. GABAS, C.M.B. ${ }^{1,2 *}$; BACILIERI, S."; FERNANDES, M.J.B.'; GALLETI, S.R. ${ }^{1}{ }^{1}$ Instituto Biológico, Av. Conselheiro Rodrigues Alves, 1252, CEP 04014900, Vila Mariana, SP, Brasil; ${ }^{2}$ Faculdade Integral Cantareira. E-mail:carlosgabas@outlook. com. Demographic characterization of "Arquivos do Instituto Biológico" (AIB) on Facebook.

O universo das publicações acadêmicas é, notadamente, realizado por e para cientistas. Visando romper este paradigma, o uso de mídias sociais tem aumentado cada vez mais no ramo, facilitando assim a disseminação de artigos e conteúdos científicos. Para atender esta demanda, a mídia mais comumente utilizada é o Facebook. No primeiro trimestre de 2018, a rede atingiu a marca de 127 milhões de usuários ativos mensais no Brasil, sendo, atualmente, a mídia mais utilizada em todo o território brasileiro. O presente trabalho teve como objetivos a caracterização demográfica dos seguidores da página da AIB no Facebook (@ArquivosIB) e a formatação dos “Top 10 artigos” e "Top 10 links”. A pesquisa foi realizada de forma exploratória no período de 11 meses (agosto de 2018 até junho de 2019), tendo-se como base de estudo a página no Facebook da AIB. Para caracterização demográfica dos seguidores e obtenção dos "Top 10", fez-se uso de uma ferramenta fornecida pela própria mídia denominada "Informações da Página". Este recurso fornece os dados demográficos referentes aos seguidores (porcentagem por sexo e faixa etária e quantidade de seguidores por região de origem) e um histórico de engajamento e visibilidade nas postagens. O levantamento dos dados demográficos da página da AIB revelou que $66 \%$ dos seguidores são do sexo feminino e $34 \%$ do sexo masculino. Quanto à faixa etária, notou-se a predominância compreendida entre 25 a 34 anos (28\% mulheres e $13 \%$ homens). Até o final do período analisado, a AIB possuía 1.013 seguidores, sendo 964 falantes da língua portuguesa (959 brasileiros e 5 portugueses). Ressalta-se que dos seguidores brasileiros, 19 são do Norte; 36 do Nordeste; 42 do Centro-oeste; 71 do Sul; 432 do Sudeste; 359 não especificaram. Vale salientar que a AIB também possui seguidores do Paraguai (8), Peru (5), EUA (4), além de mais 19 países. O "Top 10 artigos" da página da AIB apresentou um conjunto de interesse diversificado, sendo que de 10 artigos, 4 foram na área de entomologia agrícola, 2 de segurança alimentar, 2 de patologia animal, 1 de patologia vegetal e 1 de microbiologia agrícola. A faixa etária compreendida entre 25 a 34 anos sugere que os seguidores estejam relacionados a programas de pós-graduação. Por ser publicada em português, a página é seguida, em sua maioria, por pessoas falantes deste idioma. A maioria dos seguidores brasileiros é proveniente da região sudeste, provavelmente pelo fato do estado de São Paulo ser um polo de pesquisas e avanços em Ciências Agrárias e Biológicas. O "Top 10 artigos" revelou uma diversidade de interesse. O "Top 10 links" obteve maior visibilidade e engajamento na categoria "Curiosidades", pois ela abrange publicações relacionadas a cursos, concursos, dicas acadêmicas e outros assuntos pertinentes ao escopo da AIB.

*Bolsista: CNPq/PIBIC/IB 
CONHECIMENTO E EXPANSÃO DAS MÍDIAS SOCIAIS DO PERIÓDICO "ARQUIVOS DO INSTITUTO BIOLÓGICO” (AIB). GABAS, C.M.B.1,2*; BACILIERI, S.1; FERNANDES, M.J.B.1; GALLETI, S.R.1 1 Instituto Biológico, Av. Conselheiro Rodrigues Alves, 1252, CEP 04014-900, Vila Mariana, SP, Brasil. 2Faculdade Integral Cantareira, São Paulo, SP, Brasil. E-mail: carlosgabas@outlook.com. Knowledge and expansion of the social media of the "Arquivos do Instituto Biológico" (AIB) journal.

Os pesquisadores, aos poucos, reconhecem a importância de se comunicar com públicos diversos e também percebem que a divulgação de seus trabalhos em mídias sociais pode ajudá-los a avançar na carreira, aumentando a visibilidade de suas pesquisas, o engajamento com o público-alvo e o prestígio entre os colegas acadêmicos. O Twitter é a mídia mais comumente utilizada no meio acadêmico internacional. Criada em 2006, ela permite postagens de, no máximo, 280 caracteres, e possui mais de 300 milhões de usuários no mundo todo, com destaque de uso nos países falantes da língua inglesa. Outra mídia que vem ganhando força na divulgação cientifica é o Mendeley que, além de ser um gerenciador de referências, é uma rede social acadêmica. Ela possibilita a inserção de conteúdos acadêmicos via DOI, PDF ou URL, aumentando assim a visibilidade dos artigos e engajamento do público. O presente trabalho teve como objetivo ampliar os meios de divulgação científica da AIB e realizar levantamento de qual conteúdo postado no perfil do Twitter possui maior engajamento e visibilidade. Para ampliar a divulgação do conteúdo da AIB, foi criado, em 2018, seu perfil no Mendeley. Posteriormente, houve a inserção de 427 artigos já indexados no SciELO (Scientific Electronic Library Online), via DOI (Digital Object Identifier), desde janeiro de 2012 até junho de 2019. Almejando atender às exigências SciELO de divulgação científica, a AIB criou seu perfil no Twitter (@ArquivosIB), em 2015. Para a análise do "Top 10 tweets" da AIB, foi adotada a metodologia de forma exploratória. A plataforma do Twitter Analytics foi empregada para obtenção dos dados de engajamento e visibilidade das publicações. O levantamento de eventual crescimento no valor de citações e visibilidade no Mendeley foi analisado através da ferramenta "Publicações". Nela, tem-se acesso ao valor de citações em cada artigo. Porém, esses dados não podem ser utilizados para efeito de comparação, pois os valores apresentados são pertinentes a todas as citações anteriores e posteriores à criação do perfil da AIB. Para melhor análise do "Top 10 tweets", classificaram-se as postagens em quatro categorias: Artigos; Links; Humor; Outros. Esse levantamento revelou um público interessado majoritariamente na categoria "Link", pois ela abrange conteúdos relacionados a oportunidades, atualidades e curiosidades. Conclui-se que a criação do perfil da AIB no Mendeley, com posterior inserção dos artigos, foi satisfatória, pois se ampliou o número de canais onde são divulgados os artigos publicados pela AIB. O "Top 10 tweets" da AIB apresentou uma maior gama de interesse na categoria "Links".

${ }^{*}$ Bolsista: CNPq/PIBIC/IB 
DETECÇÃO DA DOENÇA DAS PENAS E BICO DOS PSITACÍDEOS (BFDV) EM UM ANACÃ (Deroptyus accipitrinus) POR MICROSCOPIA ELETRÔNICA DE TRANSMISSÃO (MET). PEDROSO, I.M.*; LUZ, LS.M.; MARTINS, A.M.C.R.P.F.; CATROXO, M.H.B. Instituto Biológico, Centro de Pesquisa de Sanidade Animal, Av. Cons. Rodrigues Alves, 1252, CEP 04014-900, São Paulo, SP, Brasil. E-mail: belmartinsbio@gmail.com. Detection of Beak and feather disease (BFDV) in an Red-fan Parrot (Deroptyus accipitrinus) by transmission electron microscopy.

O anacã (Deroptyus accipitrinus) é uma ave amazônica, sendo considerado um psitacídeo exótico e embora não esteja incluído na categoria ameaçado de extinção, sua população é constantemente afetada pelo comércio e destruição de seu habitat. A doença das penas e bico dos psitacídeos (BFDV) é causada por um circovírus pertencente à família Circoviridae, gênero Circovirus, espécie Beak and feather disease virus. A circovirose aviária é a enfermidade que mais afeta as aves exóticas jovens, sendo caracterizada por imunossupressão, necrose do fígado, pneumonia, enterite, distrofia das penas e morte. A transmissão ocorre pelo contato com fezes, alimentos e secreções contaminados e através da inalação do pó das penas. No mês de junho deste ano, durante procedimentos rotineiros de quarentena, foram colhidas amostras de fezes de um Anacã, para pesquisa de circovírus. A ave foi resgatada pela Polícia Florestal e doada a um criatório do estado de São Paulo. Após um mês, a ave apresentou alterações nas penas e foi eutanasiada. A amostra de fezes e a ave foram enviadas ao Laboratório de Microscopia Eletrônica do Instituto Biológico de São Paulo, para pesquisa do agente viral. Durante a necropsia, foi observada a presença de papo e esôfago dilatados, pulmões e fígado hemorrágicos, além de alterações na pele e penas. As fezes e os fragmentos de pele e de órgãos foram processados pela técnica de contrastação negativa, sendo suspensos em tampão fosfato $0,1 \mathrm{M}, \mathrm{pH} 7,0$, colocados em contato com grades metálicas, que foram drenadas com papel de filtro e posteriormente contrastadas negativamente com molibdato de amônia a $2 \%$. Partículas típicas de circovírus, não envelopadas, isométricas, caracterizadas como partículas "completas" e "vazias", medindo entre 17 e $20 \mathrm{~nm}$ de diâmetro, foram visualizadas em todas as amostras examinadas ao microscópio eletrônico de transmissão. A técnica aplicada foi eficiente para o diagnóstico viral rápido e tomada de medidas de controle da doença no criadouro, considerando-se que não existe tratamento efetivo e nem vacina para a doença. Este relato constitui a primeira ocorrência no Brasil de BFDV em Deroptyus accipitrinus e a primeira detecção de BFDV por microscopia eletrônica de transmissão nessa espécie.

${ }^{*}$ Bolsista CNPq/PIBIC/IB 
AVALIAÇÃO DA EFICÁCIA DE VARIEDADES DE FEIJÃO-COMUM UTILIZADAS COMO RATICIDA CASEIRO. BARBERO, N.Y. ${ }^{1 *}$; POTENZA, M.R. ${ }^{2}$; NARCISO, E.S. ${ }^{2}$ 1Universidade Metodista de São Paulo (UMESP), Rua Alfeu Tavares, 149, CEP 09641-000, São Bernardo do Campo, SP, Brasil. ' Instituto Biológico, Av. Cons. Rodrigues Alves, 1252, CEP 04014-900, São Paulo, SP, Brasil. E-mail: nybarbero@gmail.com. Evaluation of the effectiveness of common bean varieties used as home-grown rat poison.

As espécies de roedores urbanos fazem parte do grupo de pragas conhecidas como comensais ou sinantrópicas, na competição diária por alimentos, e sendo causa de grandes perdas econômicas, além de propagar doenças. Dentre essas espécies se encontram o Mus musculus, Rattus rattus e o Rattus norvegicus, os principais roedores urbanos conhecidos. Frequentemente, infestam locais onde há disponibilização de alimentos mal armazenados ou de material para construírem suas colônias. Afetam principalmente as regiões mais carentes, onde não há informações suficientes ou acesso a produtos eficientes para o controle de pragas, optando por raticidas baratos, sem efeito letal, ou até mesmo receitas caseiras disponíveis na Internet. O objetivo deste trabalho é avaliar a palatabilidade e a eficácia das variedades de feijão-comum (Phaseolus vulgaris, L.), utilizadas pela população em receitas caseiras como raticida. No bioensaio foi utilizado um grupo de roedores para cada variedade, e thes foram oferecidas $50 \mathrm{~g}$ de feijão-comum cru, $60 \mathrm{~g}$ de ração padrão e $40 \pm 1 \mathrm{~g}$ de raticida comercial para o teste de eficácia. No teste de palatabilidade, foi observado que os animais sentiram pouco interesse no alimento cru, preferindo a ração. No teste de eficácia, o comparativo feito entre a ação do raticida e do feijão cru em sua letalidade não revelou nenhuma característica física de que os valores antinutricionais do feijão-comum os tenham afetado, como diarreia ou secreção nos olhos e nariz, enquanto a ação do raticida levou todos os animais a óbito. Além de não haver consumo considerado satisfatório dos grãos de feijão, os dados obtidos permitiram concluir que os grãos de feijão-comum são ineficazes como raticida caseiro.

* Bolsista CNPq/PIBIC/IB 
VALIDAÇÃO DE GENES DA FAMÍLIA P450 EM Brevipalpus yothersi (ACARI: TENUIPALPIDAE), ÁCARO DA LEPROSE. BASSANI, J.G. ${ }^{1 *}$; SINICO, T.E. ${ }^{1,2}$; FREITAS-ASTÚA, J.2,3; FERREIRA, L.M. ${ }^{1}$; NOVELLI, V.M. ${ }^{1 ;}$; Centro Avançado de Pesquisa de Citros Sylvio Moreira- IAC, Rodovia Anhanguera Km 158, CEP 13490-970, Cordeirópolis, SP, Brasil. 2Instituto Biológico, Avenida Conselheiro Rodrigues Alves, 1252 Vila Mariana, CEP 04014-

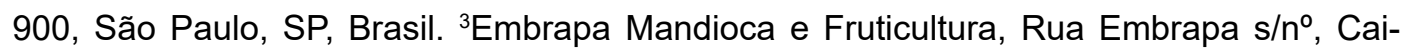
xa Postal 007, CEP: 44380-000, Cruz das Almas, BA. E-mail: jhessika.girelli@gmail.com. Validation of P450 family genes in Brevipalpus yothersi (Acari: Tenuipalpidae), leprosis mite.

Os ácaros do gênero Brevipalpus são economicamente importantes devidos sua alta polifagia e capacidade vetora de fitovírus conhecidos por VTBs (vírus transmitidos por Brevipalpus). As principais culturas afetadas por estes vírus e vetores são citros, café, maracujá e ornamentais como as orquídeas. Em citros, a leprose representa a doença viral de maior impacto, causada pelo citrus leprosis virus C (CiLV-C) e transmitido comumente pela espécie Brevipalpus yothersi. Na maioria dos pomares, o manejo desta doença é feito com uso de acaricidas, dos quais há poucas moléculas eficazes, implicando em alto investimento e iminente risco de resistência dos ácaros e danos ambientais. Portanto, são cada vez mais necessários os estudos voltados ao patossistema leprose, particularmente do vetor, sua genética e suas interações. Dados de transcriptoma (RNAseq) de $B$. yothersi, em resposta ao CiLV-C, indicaram diversas categorias de genes diferencialmente expressos (GDE). Destes genes, os da família citocromo P450 despertaram grande interesse dado envolvimento nos processos de detoxificação e metabolismo de xenobióticos em artrópodes. Portanto, considerando a importância deste ácaro como vetor, sua alta polifagia e potencial de resistência nos pomares, o objetivo deste trabalho foi validar alguns destes genes da família P450 (clã CYP3), previamente identificados. De acordo com as sequências dos genes CYP3 obtidas do transcriptoma de B. yothersi foram desenhados (PrimerQuest) e sintetizados iniciadores específicos. Amostras de ácaros, mantidas em frutos sadios de laranjeira doce, foram utilizadas para extração de RNA total, síntese de cDNA, RT-PCR, e sequenciamento dos amplicons para confirmação dos genes. No total, foram amplificadas e validadas 10 sequências para genes do clã CYP3 do ácaro da leprose, com fragmentos variando de 100 a 140 pb. Estes genes serão investigados quanto ao diferencial de expressão de $B$. yothersi mantidos sobre diferentes hospedeiras, buscando correlacionar o envolvimento de CYP3 aos processos de detoxificação. Os resultados contribuirão com informações inéditas sobre esse vetor e com o avanço para entendimento das interações vírus-vetor-hospedeira. Apoio: FAPESP 2016/21749-8; 2019/03267-4. 
CORRELAÇÕES GENÉTICAS ENTRE VALORES GENÉTICOS ADITIVOS DE ESCORES VISUAIS E CARACTERÍSTICAS REPRODUTIVAS EM BOVINOS NELORE. ALMEIDA, C. A. ${ }^{1}$; MEDEIROS, G. C. ${ }^{* *}$; ABREU SILVA, B.C. ${ }^{1^{* *}}$; BUSSIMAN, F.O.; EGUTI, F.C.; MATTOS, E.C.; ELER, J.P.; FERRAZ, J.B.S. Universidade de São Paulo, Faculdade de Zootecnia e Engenharia de Alimentos, Av. Duque de Caxias Norte 225, CEP 13635-900, Pirassununga, SP, Brasil; ${ }^{2}$ Universidade de São Paulo, Faculdade de Medicina Veterinária e Zootecnia, Av. Duque de Caxias Norte 225, CEP 13635-900, Pirassununga, SP, Brasil. E-mail: carolineassisalmeida@gmail.com. Genetic correlation between additive values of visual scores and reproductive traits in Nellore cattle.

As diferenças esperadas na progênie (DEPs) para escores visuais tem sido empregados em programas de melhoramento genético com a finalidade de identificar animais superiores para a produção de carne, porém outras características também são essenciais para o sistema de produção, por exemplo, as características reprodutivas, que estão altamente ligadas a intensidade de seleção e ao intervalo entre gerações. O objetivo deste estudo foi estimar os coeficientes de correlação genética entre as DEPs para características de escores visuais e características reprodutivas de fêmeas do programa de melhoramento realizado pelo Núcleo de Apoio à Pesquisa em Melhoramento Animal, Biotecnologia e Transgenia do Departamento de Medicina Veterinária da Faculdade de Zootecnia e Engenharia de Alimentos da Universidade de São Paulo em parceria com a Agropecuária CFM. O banco de dados foi composto por 345.841 animais nascidos entre as safras de 1950 a 2017. Foram estimadas as correlações de Pearson entre as DEPs. As características avaliadas foram: a conformação (conf), a precocidade (prec), a musculosidade (musc), o umbigo (umb), a ossatura (oss), a probabilidade de prenhez aos 14 meses (pp14), a habilidade de permanência aos 6 anos no rebanho (stay) e a produtividade de vaca (prodam). Todas as estimativas dos coeficientes de correlação se apresentaram positivas, variando entre 0,06 a 0,99 , as correlações genéticas entre escores visuais variaram de 0,18 a 0,99 e, entre as características reprodutivas variaram de 0,78 a 0,99 . Os coeficientes de correlação encontrados foram: conf e prec $(0,96)$; conf e musc $(0,95)$; conf e umb $(0,18)$; conf e oss $(0,76)$; conf e pp14 $(0,46)$, conf e prodam $(0,34)$; conf e stay $(0,32)$; prec e musc $(0,99)$, prec e umb $(0,18)$; prec e oss $(0,77)$; prec e pp14 $(0,51)$; prec e prodam $(0,37)$; prec e stay $(0,35)$; musc e umb $(0,18)$; musc e oss $(0,77)$; musc e pp14 $(0,51)$; musc e prodam $(0,38)$; musc e stay $(0,35)$; umb e oss $(0,21)$; umb e pp14 $(0,10)$; umb e prodam $(0,06)$; umb e stay $(0,06)$; oss e pp14 $(0,39)$; oss e prodam $(0,26)$; oss e stay $(0,22)$; pp14 e prodam $(0,78)$; pp14 e stay $(0,78)$; prodam e stay $(0,99)$. Essa grande variação entre as correlações é dada devido à baixa correlação do umbigo com as outras variáveis, exceto para ossatura $(0,21)$. Os escore visuais, com exceção do umbigo, possuem correlações genéticas de moderada a alta magnitude entre si, do mesmo modo que as características reprodutivas, indicando que a seleção direta para uma dessas características ocasionará, consequentemente, no progresso genético nas outras.

\footnotetext{
*Bolsista CNPq (PIBIC)

${ }^{* *}$ Bolsista CAPES (DS)

${ }^{* * *}$ Bolsista FAPESP
} 
TENDÊNCIAS GENÉTICAS ENTRE ESCORES VISUAIS E CARACTERÍSTICAS REPRODUTIVAS EM BOVINOS NELORE. ALMEIDA, C.A.; MEDEIROS, G.C.; ABREU SILVA, B.C.; BUSSIMAN, F.O.; EGUTI, F.C.; MATTOS, E.C.; ELER, J.P.; FERRAZ, J.B.S. Universidade de São Paulo, Faculdade de Zootecnia e Engenharia de Alimentos, Av. Duque de Caxias Norte 225, CEP 13635-900, Pirassununga, SP, Brasil; 'Universidade de São Paulo, Faculdade de Medicina Veterinária e Zootecnia, Av. Duque de Caxias Norte 225, CEP 13635-900, Pirassununga, SP, Brasil. E-mail: carolineassisalmeida@gmail.com. Genetic trends between visual scores and reproductive traits in Nellore cattle.

Os criadores de bovinos de corte e pesquisadores, cada vez mais se preocupam com as consequências da seleção a longo prazo, por essa razão, se faz o uso do estudo de tendências genéticas, visto que é uma forma clara e simples de se avaliar o progresso genético de uma dada característica. O objetivo desse estudo foi estimar e avaliar a tendência genética de escores visuais e características reprodutivas. Foram analisados os valores genéticos aditivos de 225.744 animais nascidos entre 1992 à 2017. O banco de dados estava sob a responsabilidade do Núcleo de Apoio à Pesquisa em Melhoramento Animal, da Faculdade de Zootecnia e Engenharia de Alimentos da Universidade de São Paulo, com dados dos rebanhos pertencentes à Agropecuária CFM, uma empresa pioneira nesse trabalho e líder de mercado de venda de reprodutores da raça há vários anos. Foram estimados os coeficientes de regressão linear simples dos valores genéticos regredidos sob os respectivos anos de nascimento. As características analisadas foram: conformação (CONF), precocidade (PREC), musculosidade (MUSC), umbigo (UMB), ossatura (BONE SCORE), probabilidade de prenhez aos 14 meses (PP14), habilidade de permanência aos 6 anos no rebanho (STAY) e produtividade da vaca (PRODAM). Os coeficientes de regressão foram positivos com valores de: BONE SCORE (0,22 un/ano); UMB (0,002 un/ ano); MUSC (0,03 un/ano); PREC (0,03 un/ano); CONF (0,03 un/ano); PP14 (0,61\%/ano); PRODAM (0,24 kg/ano); e STAY (0,34 \%/ano). As características, com exceção de umbigo, apresentaram tendência linear positiva, mostrando que houve aumento do valor genético durante os anos. Observa-se no gráfico de tendência do umbigo uma oscilação expressiva no ganho genético anual. Os escores visuais apresentam um aumento linear importante, o que pode ser atribuído ao uso dessas características como critério de seleção pelo programa de melhoramento. As características reprodutivas apresentaram um aumento linear expressivo somente a partir de 2002, pois neste período houve a intensificação da seleção destas características no programa de melhoramento. Os resultados deste estudo indicaram que houve aumento favorável dos valores genéticos para todas características estudadas, indicando a adequação do sistema de seleção aplicado, o que representa uma melhoria a longo prazo no desempenho dos animais.

*Bolsista CNPq (PIBIC)

${ }^{* *}$ Bolsista CAPES (DS)

${ }^{* * *}$ Bolsista FAPESP 


\section{índice por autor}

ABREU SILVA, B.C. $-28,29,30,31,47,48$

ACERO VADERRAMA, A.S. -30

ACERO VADERRAMA, A.S. -31

ALEXANDRE, M.A.V. - 10

ALMEIDA, C.A. $-28,29,47,48$

ALMEIDA, I.B. -38

ALMEIDA, J.E.M. - 02

ALVES, B.C. -03

ALVIM, A.P.C.S. -36

ARAUJO, L.A.C. -05

ARAÚJO, M.C.S. -36

ARAUJO, S.B.S. -38

ASTÚA-FREITAS, J. - 06

BACILIERI, S. $-42,43$

BARBERO, N.Y. -45

BASSANI, J.G. - 45

BERIAM, L.O.S. - 23

BERNACCI, L.C. -10

BERSANO, J.G. -35

BEZERRA, L.S. -25

BLANCO, F.M.G. -26

BUENO, B.I. -24

BUENO, C.J. $-01,22$

BUSSIMAN, F.O. $-28,29,30,31,47,48$

CAMPOLI, C.C. -33

CARUSO, C. -34

CATROXO, M.H.B. $-35,44$

CHABI-JESUS, C. -07

CHACÓN-OROZCO, J. - 22

CHAVES, A.L.R. - 08, 09, 10

CHIEBAO, D.P. $-34,36,37$

CONTENTO, F.M. - 01

CRUZ, B.S. $-20,21$

DEL FAVA, C. - 36

DESTEFANO, S.A.L. - 24

DEUS, B.C. -25

DIZ, S.M.L. -36

DOMINGOS, A. - 34, 37

DUARTE, A.P. - 11

DUARTE, F.C. -38

DUARTE, L.M.L. - 10
EGUTI, F. C. - 28, 29, 47, 48

EIRAS, M. - 08, 09, 17

ELER, J.P. - 28, 29, 30, 31, 47, 48

EULALIO, J. -05

FERNANDES, M.J.B. $-42,43$

FERRAZ, J.B.S. - 28, 29, 30, 31, 47, 48

FERREIRA, L. de F. -39

FERREIRA, L.M. - 16, 46

FERREIRA, N. -22

FERREIRA, R.C.B. $-40,41$

FIORINI, L.C. -38

FONSECA, A.A. -36

FONSECA, G.A. -25

FRANCO, G.M. -27

FRANCO, K.P.A.C. $-18,19$

FREITAS-ASTÚA, J. - 07, 12, 46

FURLAN, B.P. -38

GABAS, C.M.B. $-42,43$

GALDEANO, D.M. -16

GALLETI, S.R. $-42,43$

GOMES, C. G. -23

GOMES, F.R. - 39

GONÇALVES, M.C. -11

GONÇALVES, R.C. -36

GRIGOLETTO, L. - 30, 31

HARAKAVA, R. - 08, 11

HILST, V.C. -37

IDE, S. $-18,19$

KITAJIMA, E.W. - 08, 12

KUBO, R.K. - 05

LEAL, M.B. -14

LEITE, L. G. -22

LEZIER, D.H. -36

LIMA, A.S. -39

LIMA, E.F.B. -17

LIMA, G. $-20,21$

LOUZEIRO, L.R.F. - 20, 21

LUZ, L.S.M. $-35,44$

MACHADO, M.A. -16

MAGRINHO, F.C.B. -36

MARÇAL, J.F. -13 
MARQUES, G.H.F. - 36

MARQUES, S.S. -13

MARTINEZ, R.R. - 34

MARTINS, A.M.C.R.P.F. $-35,44$

MATTOS, E.C. - 28, 29, 30, 31, 47, 48

MEDEIROS, G.C. $-28,29,47,48$

MENDES, M. C. - 38

MINEIRO, J.L.C. - 14, 15

MIYASATO, E.A. - 17

MONTEIRO, B. - 34

MONTEIRO, T.S.F. -26

MOURA, C.J.M. -09

MOURA, S.S. -09

NARCISO, E.S. - 45

NASCIMENTO, T. - 11

NASSAR, A.F.C. -36

NOVELLI, V.M. - 16, 46

NOWAKONSKI, E.V. - 02

NUNES, M.A. - 16

OGATA, R.A. - 35

OKUDA, L.H. - 34, 37

OLIVEIRA, A.M. - 08

OLIVEIRA, C.G. - 03

OLIVEIRA, C.M.G. - 04

OLIVEIRA, E.T. - 26

OLIVEIRA, L.A. - 17

OTOYA-MARTINEZ, N. - 22

PASSOS, V.T. - 32, 33

PATRÍCIO, F.R.A. - 25

PEDROSO, I.M. - 35, 44

PEREIRA, E.S.- 13

PEREIRA, M.V.M. - 10

PETROCELLI, B.M. - 40, 41

PITUCO, E.M. - 34, 36

POMPEI, J.C.A. -36

POTENZA, M.R.- 27, 45

POTSCLAM-BARRO, CHABI-JESUS, C.M. - 12

POTSCLAM-BARRO, M. -07
RAGA, A. - 20, 21

RAMOS-GONZÁLEZ, P.L. - 06, 07, 12

RIGAMONTE, B.L. - 32, 33

RODRIGUES, L.K. - 08

RODRIGUES, M.C. $-07,12$

RODRIGUES, R.M.P. - 15

ROMALDINI, A.H.C.N. - 34, 36, 37

ROMERA, D.M. - 32, 33

ROSA, J.M.O. - 03, 04

SAMPAIO, P. H. S. -38

SANTANA, B.F. $-30,31$

SANTANA, J. R. - 04

SANTOS, C.B. -36

SATO, M.E. - 13, 14, 15

SCHAAAF BENFICA, C. - 06

SEVÁ, A.P. - 37

SILVA, G.S. $-32,33$

SILVA, R.A. - 32, 33

SILVA, V.V.S. -08

SIMÕES, H.M.Q. - 36

SINICO, T.E. - 46

SOUZA, A.C.O. - 10

SOUZA, C.S.M. - 40, 41

SOUZA, D.S. -02

SOUZA, G.S. -40

SOUZA-FILHO, M..F. - 20, 21

STEFANO, E. - 34

STURARO, M.J.R. - 34

TANCREDO, A.L.G. - 01

TASSI, A.D. - 12

TEIXEIRA, I.N. - 18, 19

TITON, S.C.M. -39

VECCHIO, D. - 34

VIEIRA, E. - 40, 41

VIZIGALI, A.C.C. - 34

YAMAKAWA, W. - 18

YARA, P.M. - 08

ZANCO, G.J. - 34 


\section{Palavras chave / Keywords}

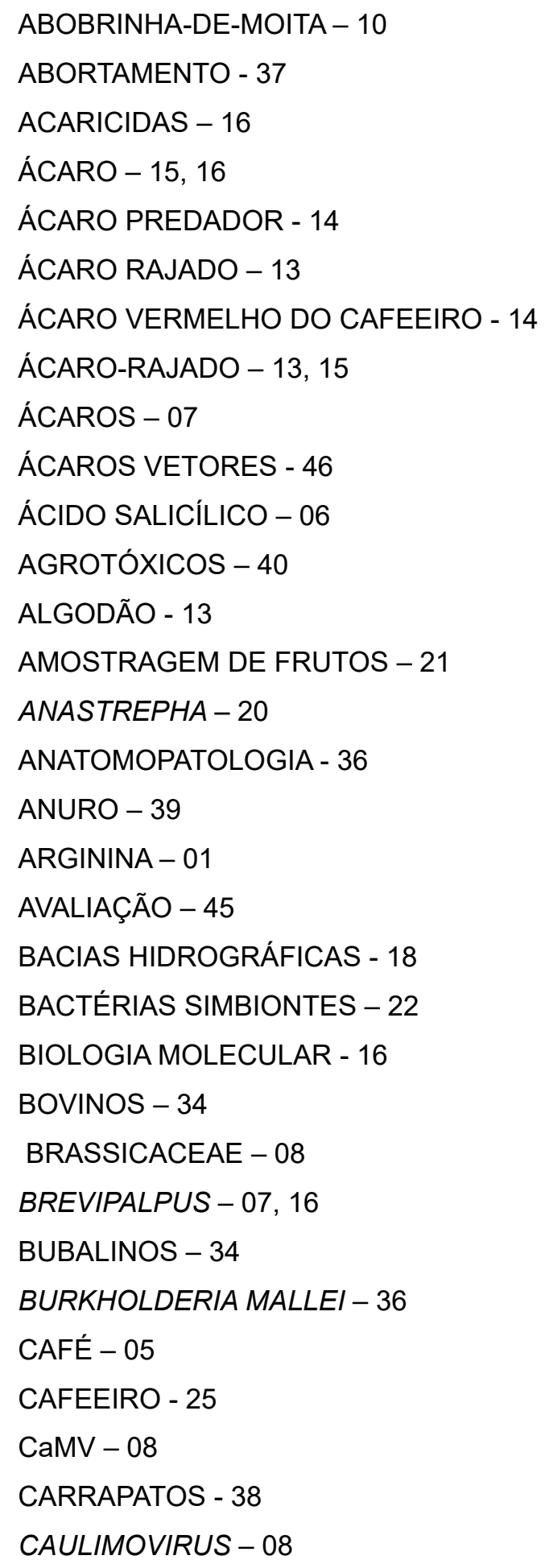




\section{7으 CICAM}

Congresso de Iniciação Científica em Ciências Agrárias, Biológicas e Ambientais

Palavras chave / Keywords

GENÉTICA - 28, 47, 48

GOLFE - 03

HELMINTOS - 33

HERDABILIDADE - 31

HERPESVIRUS - 34

IMATUROS - 19

IMUNIDADE INATA - 39

ÍNDICE DE PARASITISMO - 21

INDUTORES DE RESISTÊNCIA - 25

INFESTAÇÃO - 20

INSECTA - 18

INTERAÇÃO - 05

INTERAÇÃO VETOR-HOSPEDEIRO - 46

LEPROSE DOS CITROS - 16

LEVANTAMENTO - 18, 27

MAMÃO - 13

MANCHA AUREOLADA - 24, 25

MANCHA BACTERIANA - 23

MELHORAMENTO GENÉTICO - 31

MELOIDOGYNE GRAMINIS - 03

MENDELEY - 43

METABOLISMO DE XENOBIÓTICOS - 46

METABÓLITOS - 22

MICROSCOPIA ELETRÔNICA DE

TRANSMISSÃO - 35, 44

MILHO - 11

MODELAGEM - 31

MODELO LOGÍSTICO - 26

MORANGO - 13

MORFOESPÉCIES - 17

NEMATOIDES - 04, 05, 22

OFV -12

OLERICULTURA - 09

OLIVEIRA - 04
OPG - 32, 33

OVINOS - 32, 33

OVIPOSIÇÃO - 15

PERIÓDICO - 43

PERIÓDICO CIENTÍFICO - 42

POTYVÍRUS - 10

PRAGAS - 27

PRODUÇÃO - 28, 29, 47, 48

PSEUDOMONAS SYRINGAE PV. GARCAE

$-24,25$

PSEUDOMONAS SYRINGAE PV. TABACI24

PSYLLOBORA - 19

RAÇÕES INDUSTRIALIZADAS - 27

RATICIDA - 45

REPRODUÇÃO - 28, 29, 47, 48

RESÍDUO - 26

ROTAÇÃO DE CULTURAS - 26

ROTAVÍRUS - 35

RT-PCR - 12

SEQUENCIAMENTO - 11

SEROLOGIA - 23

SINGÔNIO - 13

SOJA PERENE - 13

SUÍNOS - 35

TÉCNICA DE IMUNOCITOQUÍMICA - 35

TEMPERATURA - 39

TETRANYCHUS URTICAE - 15

TOMATE - 13

TOMATEIRO - 23

TOXICIDADE DE DSGFP - 16

TOXOPLASMOSE - 37

TRIPES - 17

TRIPES DE SOLO - 17 


\section{7으 CICAM}

Congresso de Iniciação Científica em Ciências Agrárias, Biológicas e Ambientais

Palavras chave / Keywords

TWITTER - 43

VÍRUS - 11

VÍRUS DE PLANTAS - 09

VTB -07

\section{Keywords}

ABORTION - 37

ANALYSIS - 16

ANASTREPHA - 20

ANATOMOPATHOLOGY - 36

ANIMAL IMPROVEMENT - 31

ANTIVIRAL -10

ANURAN - 39

ARGININE - 01

ARROWHEAD PHILODENDRON - 13

BACTERIAL BLIGHT OF COFFEE - 25

BACTERIAL DISEASES ON COFFEE - 24

BACTERIAL HALO BLIGHT - 24

BACTERIAL LEAF SPOT - 24

BACTERIAL SPOT - 23

BEAN - 45

BIOLOGICAL CONTROL - 14, 21

BOVINE - 37

BRASSICACEAE - 08

BREVIPALPUS - 07

BTV - 07

BUFALLOES - 34

BURKHOLDERIA MALLEI - 36

CAMV - 08

CARRYOVER - 26

CAULIMOVIRUS - 08

CERATITIS CAPITATA - 20

CHAYOTE - 13

CILEVIRUS - 12
CiLV-C - 07

CIRCOVIRUS - 44

CITRUS LEPROSIS - 06, 16

COFFEE - 05

COFFEE PLANTATION - 25

CONTROL - 01, 03, 38

CORRELATION - 29

COTTON - 13

DEROPTYUS ACCIPITRINUS - 44

DESCRIPTION - 19

DICHORHAVIRUS - 12

DIVERSITY - 17

DSGFP - 16

E.COLI - 40

ENDOPLASMIC RETICULUM STRESS - 06

ENZYME - 01

EPG - 33

EPIDEMIOLOGY - 09

EQUUS CABALLUS - 36

FACEBOOK - 42

FERTILIZERS - 40

FRUITS SAMPLING - 21

FUNGI - 38

GENETICS - 28, 47, 48

GOLF - 03

HARAS - 38

HELMINTHES - 33

HERITABILITY - 31

HOST-VECTOR INTERACTION - 46

IMMATURE - 19

IMMUNOCYTOCHEMISTRY

TECHNIQUE - 35

INDUSTRIALIZED PET FOOD - 27

INFESTATION - 20 


\section{7으 CICAM}

Congresso de Iniciação Científica em Ciências Agrárias, Biológicas e Ambientais

Palavras chave / Keywords

INNATE IMMUNITY - 39

INSECTA - 18

INTERACTION - 05

LIQUID CHROMATOGRAPH - 41

LIQUID-LIQUID EXTRACTION - 41

LOGISTIC MODEL - 26

MAIZE - 11

MELOIDOGYNE GRAMINIS - 03

MENDELEY - 43

METABOLITES - 22

MITE - 07, 15, 16

MODELING - 31

MORFOESPÉCIES - 17

NEMATODE - 05

NEMATODES - 04

NEMATOID - 22

OFV - 12

OLERICULTURE - 09

OLIVE - 04

OVIPOSITION - 15

PAPAYA - 13

PARASITISM INDEX - 21

PERENNIAL SOYBEAN - 13

PESTICIDES - 40

PESTS - 27

PLANT VIRUSES - 09

PLANT-PARASITIC - 04

POTYVIRUS - 10

PREDATORY MITE - 14

PRODUCTION - 28, 29, 47, 48

PSEUDOMONAS SYRINGAE PV.

GARCAE - 24, 25

PSYLLOBORA - 19

RAT - 45
REPRODUCTION - 28, 29, 47, 48

RESIDUE - 26

RESISTANCE INDUCTORS - 25

ROTAVIRUS - 35

RT-PCR - 12

SALICYLIC ACID - 06

SCIENTIFIC JOURNAL - 42, 43

SEQUENCING - 11

SEROLOGICAL DIAGNOSIS - 34

SEROLOGY - 23

SHEEP - 33

SOCIAL MEDIA - 42

SOIL THRIPS - 17

SOUTHERN RED MITE - 14

STRAWBERRY - 13

SURVEY - 18, 27

SWINE- 35

SYMBIOTIC BACTERIA - 22

TEMPERATURE - 39

TETRANYCHUS URTICAE - 15

THERMOTOLERANT COLIFORMS - 40

THRIPS - 17

TOMATO - 13, 23

TOXOPLASMOSIS - 37

TRANSMISSION ELECTRON

MICROSCOPY - 35, 44

TWITTER - 43

TWO-SPOTTED SPIDER MITE - 13

VARIETIES - 45

VECTORS MITE - 46

VIRUS - 11

WATERSHEDS - 18

XENOBIOTIC METABOLISM - 46

ZUCCHINI - 10 


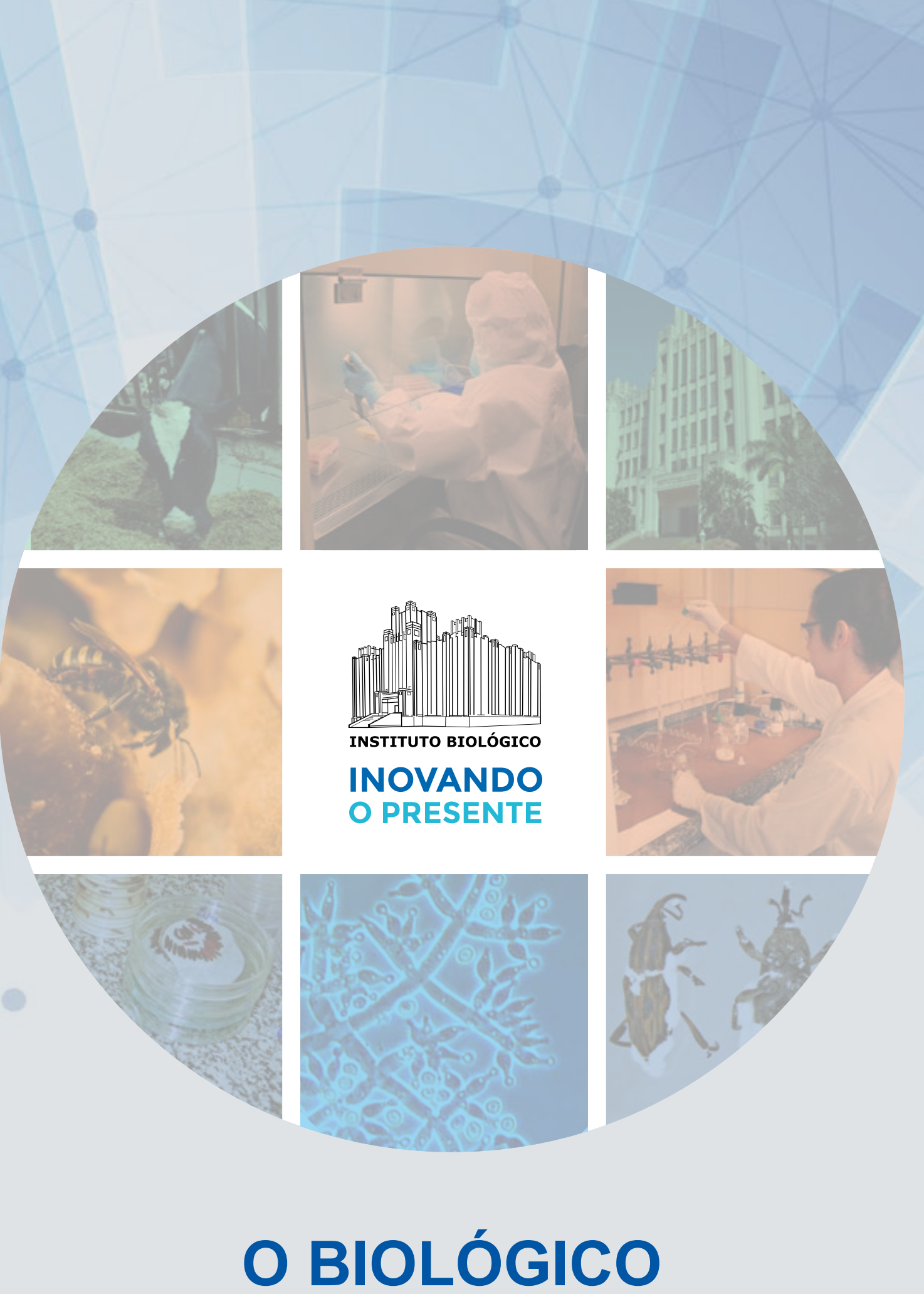

Suplemento | Volume 81 | Número 1 | Setembro-2019 